\title{
Electromagnetic Borehole
} Flowmeter Surveys at Selected In Situ Redox Manipulation Barrier Wells, Zero-Valent Iron Site, Hanford, Washington

\author{
DR Newcomer
}

February 2009

Pacific Northwest

NATIONAL LABORATORY 


\title{
DISCLAIMER
}

This report was prepared as an account of work sponsored by an agency of the United States Government. Neither the United States Government nor any agency thereof, nor Battelle Memorial Institute, nor any of their employees, makes any warranty, express or implied, or assumes any legal liability or responsibility for the accuracy, completeness, or usefulness of any information, apparatus, product, or process disclosed, or represents that its use would not infringe privately owned rights. Reference herein to any specific commercial product, process, or service by trade name, trademark, manufacturer, or otherwise does not necessarily constitute or imply its endorsement, recommendation, or favoring by the United States Government or any agency thereof, or Battelle Memorial Institute. The views and opinions of authors expressed herein do not necessarily state or reflect those of the United States Government or any agency thereof.

\author{
PACIFIC NORTHWEST NATIONAL LABORATORY \\ operated by \\ BATTELLE \\ for the \\ UNITED STATES DEPARTMENT OF ENERGY \\ under Contract DE-AC05-76RL01830 \\ Printed in the United States of America \\ Available to DOE and DOE contractors from the \\ Office of Scientific and Technical Information, \\ P.O. Box 62, Oak Ridge, TN 37831-0062; \\ ph: (865) 576-8401 \\ fax: $(865) 576-5728$ \\ email: reports@adonis.osti.gov
}

\footnotetext{
Available to the public from the National Technical Information Service,

U.S. Department of Commerce, 5285 Port Royal Rd., Springfield, VA 22161

ph: (800) 553-6847

fax: (703) 605-6900

email: orders@ntis.fedworld.gov

online ordering: http://www.ntis.gov/ordering.htm
} 


\section{Electromagnetic Borehole Flowmeter Surveys at Selected In Situ Redox Manipulation Barrier Wells, Zero-Valent Iron Site, Hanford, Washington}

DR Newcomer

February 2009

Prepared for

MSE Technology Applications, Inc. under U.S. Department of Energy

Contract DE-AC05-76RL01830 


\section{Executive Summary}

Ambient (i.e., static) and dynamic (i.e., pumping-induced) electromagnetic borehole flowmeter (EBF) surveys were performed in 10 selected In Situ Redox Manipulation (ISRM) barrier wells to characterize the distribution of in-well vertical flow conditions and to infer the relative hydraulic conductivity distribution in the upper-part of the unconfined aquifer. These wells are located in two areas where the aquifer is targeted for testing of zero-valent iron injection to mend a failed portion of the ISRM barrier at the 100-D Area, Hanford Site. Each of these two areas consists of a group of five wells, one group to the southwest and one group to the northeast. The upper $\sim 15$ to $20 \mathrm{ft}(\sim 4.6$ to $6.1 \mathrm{~m})$ of the unconfined aquifer was characterized for in-well vertical flow conditions and vertical profile information regarding relative hydraulic conductivity. At some well site locations, the upper $\sim 2$ to $3 \mathrm{ft}(\sim 0.6$ to $1 \mathrm{~m})$ of the wellscreen interval could not be characterized under pumping (dynamic) conditions because of the presence of the pump.

Ambient EBF survey data within most wells indicated low, but measurable, upward flow in most of the well-screen intervals with upward ambient flow rates ranging up to a maximum of $0.14 \mathrm{gpm}$ (0.53 L/min). At three of the wells tested (199-D4-91, 199-D4-92, and 199-D4-93), downward in-well flow rates ranged up to a maximum of $0.11 \mathrm{gpm}(0.42 \mathrm{~L} / \mathrm{min})$ within the upper-part of the well-screen test intervals. Probable causes of ambient vertical flow conditions include aquifer vertical heterogeneity and river-stage boundary fluctuations.

Dynamic vertical flow conditions were successfully characterized for well-screen test intervals in 7 of the 10 wells surveyed with the EBF. However, it was necessary to correct net dynamic flow (i.e., induced minus ambient flow) for vertical bypass flow past the EBF probe (i.e., between the probe and well screen) and through the high-permeable sand pack surrounding the well screen. Bypass flow was attributed to an imperfect seal between the EBF probe and the well screen because longitudinal spacer ribs lined the inside of the screen, and an undersized seal diameter had to be used to access the 10.2-cm (4-in.) insidediameter polyvinyl chloride screens via the $9.2-\mathrm{cm}$ (3 5/8-in.) casing. The presence of blank joint sections within the stainless steel well-screen section provided the opportunity for a complete inflatable packer seal and the means to estimate the proportion of bypass flow between the inflated packer and the well screen in three of the wells tested (199-D4-25, 199-D4-26, and 199-D4-27). The proportion of bypass flow between the inflated packer and the well screen for these wells ranged from $8 \%$ to $44 \%$. Bypass flow was also attributed to vertical flow through a high-permeable sand pack surrounding the well screen. Because the water table was above the top of the well screen for two of the wells tested (199-D4-25 and 199-D4-26), EBF flow could be measured in the blank casing. The proportion of bypass flow through the sand pack for these two wells was estimated to range up to $33 \%$ of the measured EBF flow.

For 3 of the 10 wells tested (199-D4-37, 199-D4-40, and 199-D4-92), EBF survey data showed significant vertical bypass flow through the sand pack surrounding the well screen. Analysis of the EBF data displaying significant sand pack bypass flow will lead to an erroneously high permeability zone at the top of the well-screen section. Because of this, relative hydraulic conductivity profiles could not be quantitatively determined for the well-screen test intervals at these three wells with the EBF survey data.

The net dynamic flow data were used to calculate normalized hydraulic conductivity for the seven wells successfully characterizing vertical flow conditions by the EBF probe. For the southwest group of 
wells (199-D4-25, 199-D4-26, 199-D4-27, and 199-D4-93), the dynamic flow profiles indicate a generally uniform distribution of relative hydraulic conductivity above a higher zone of relative hydraulic conductivity in the lower portion of the well-screen sections. For the northeast group of wells (199-D4-36, 199-D4-90, and 199-D4-91), the relative hydraulic conductivity distributions indicate that the highest values of relative hydraulic conductivity occur in the middle portion of the well-screen sections. 


\section{Acronyms}

$\begin{array}{ll}\text { DOE } & \text { U.S. Department of Energy } \\ \text { EBF } & \text { electromagnetic borehole flowmeter } \\ \text { ISRM } & \text { In Situ Redox Manipulation } \\ \text { MZVI } & \text { micron-sized zero-valent iron } \\ \text { PST } & \text { Pacific Standard Time } \\ \text { PVC } & \text { polyvinyl chloride }\end{array}$




\section{Acknowledgments}

Those acknowledged include field support by Jason Modrell of MSE and Fluor Hanford staff, including Curt Kooiker. Frank Spane provided technical peer review comments, Dave Lanigan provided graphics support, and Wayne Cosby provided editorial review comments. 


\section{Contents}

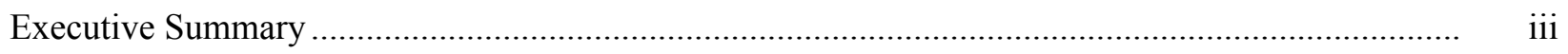

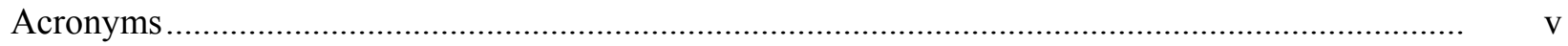

Acknowledgments......................................................................................................... vii

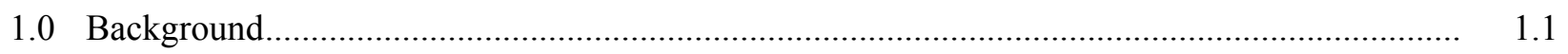

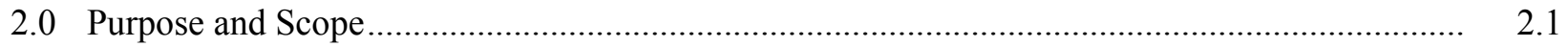

3.0 Electromagnetic Borehole Flowmeter Survey Description ................................................... 3.1

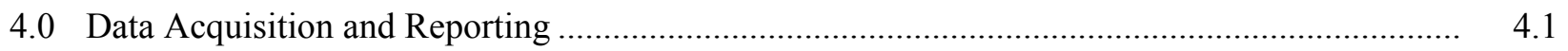

5.0 Electromagnetic Borehole Flowmeter Calibration ............................................................. 5.1

6.0 Electromagnetic Borehole Flowmeter Survey Analyses ...................................................... 6.1

7.0 Electromagnetic Borehole Flowmeter Survey Results ......................................................

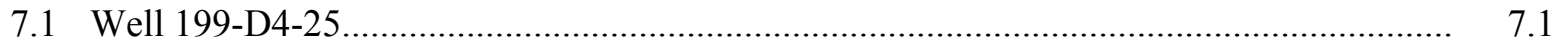

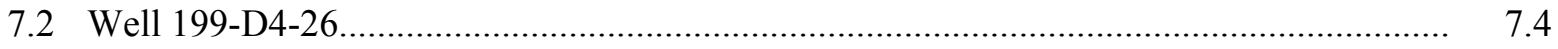

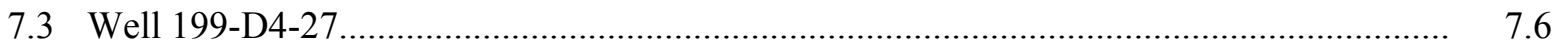

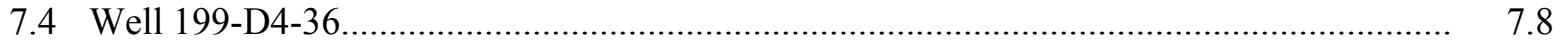

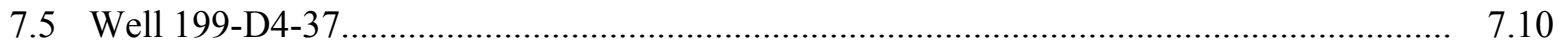

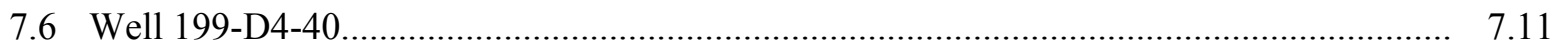

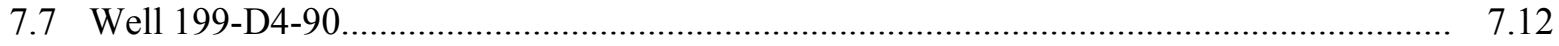

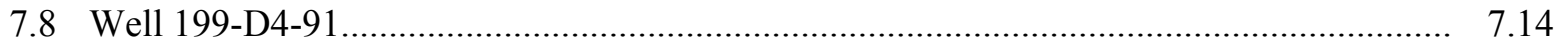

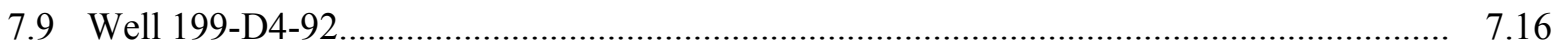

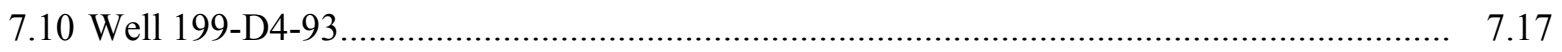

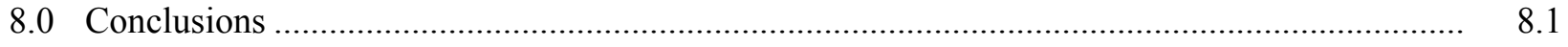

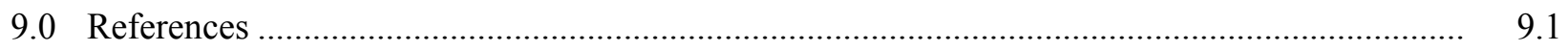

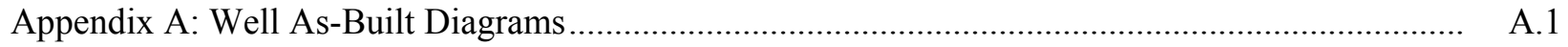

Appendix B: Summary of Electromagnetic Borehole Flowmeter Analysis Results .......................... B.1 


\section{Figures}

3.1. Map of ISRM Wells Surveyed by the Electromagnetic Borehole Flowmeter ......................... 3.1

3.2. General Electromagnetic Borehole Flowmeter Configuration ............................................. 3.2

5.1. Electromagnetic Borehole Flowmeter Calibration Results .................................................. 5.1

7.1. Ambient and Dynamic Vertical Flow Profiles, Well 199-D4-25 ............................................. 7.3

7.2. Relative Hydraulic Conductivity Profile, Well 199-D4-25 ....................................................

7.3. Ambient and Dynamic Vertical Flow Profiles, Well 199-D4-26 ............................................ 7.5

7.4. Relative Hydraulic Conductivity Profile, Well 199-D4-26 .....................................................

7.5. Ambient and Dynamic Vertical Flow Profiles, Well 199-D4-27 ........................................... 7.7

7.6. Relative Hydraulic Conductivity Profile, Well 199-D4-27 .................................................... 7.7

7.7. Ambient and Dynamic Vertical Flow Profiles, Well 199-D4-36 ............................................. 7.9

7.8. Relative Hydraulic Conductivity Profile, Well 199-D4-36 ....................................................

7.9. Ambient and Dynamic Vertical Flow Profiles, Well 199-D4-37 ........................................... 7.11

7.10. Ambient and Dynamic Vertical Flow Profiles, Well 199-D4-40 ............................................... 7.12

7.11. Ambient and Dynamic Vertical Flow Profiles, Well 199-D4-90 ............................................. 7.13

7.12. Relative Hydraulic Conductivity Profile, Well 199-D4-90 .................................................... 7.13

7.13. Ambient and Dynamic Vertical Flow Profiles, Well 199-D4-91 .............................................. 7.15

7.14. Relative Hydraulic Conductivity Profile, Well 199-D4-91 ...................................................... 7.15

7.15. Ambient and Dynamic Vertical Flow Profiles, Well 199-D4-92 ........................................... 7.17

7.16. Ambient and Dynamic Vertical Flow Profiles, Well 199-D4-93 ............................................ 7.18

7.17. Normalized Hydraulic Conductivity Profile, Well 199-D4-93 ............................................... 7.18

\section{Tables}

4.1. Summary of Pertinent Well Information ......................................................................

7.1. Summary of EBF Survey Information............................................................................ 


\subsection{Background}

The In Situ Redox Manipulation (ISRM) barrier was emplaced to remediate a chromium plume in Hanford's 100-D Area groundwater by injecting sodium dithionite into the aquifer, thereby creating a chemically reduced environment to reduce dissolved $\mathrm{Cr}^{6+}$ to $\mathrm{Cr}^{3+}$ (Williams et al. 2000). Approximately 18 months after barrier emplacement, localized signs of failure in the barrier were discovered in some wells as defined by the presence of $\mathrm{Cr}^{6+}$ in the treated wells. The most probable cause of the premature breakdown in the barrier was determined to be aquifer heterogeneities associated with laterally discontinuous units characterized by high permeability and lower inherent reductive capacity (due to lower iron content) that were re-oxidized more rapidly than the less-permeable units. A Technical Assistance Panel recommended that an alternative technology, such as micron-sized zero-valent iron (MZVI) be tested and possibly deployed in the field to mend the failed portion of the barrier and to eliminate the need to re-inject the ISRM wells with sodium dithionite (DOE 2004). The areas exhibiting the highest level of barrier breakdown and thus targeted for MZVI injection are near the two wells 199-D4-26 and 199-D4-37 (Figure 3.1). Each of these two areas also consists of a cluster of four wells located approximately $4.0 \mathrm{~m}(13 \mathrm{ft})$ upgradient and downgradient of the two wells. 


\subsection{Purpose and Scope}

One of the primary causes of the premature breakdown in reductive capacity of the aquifer at the ISRM barrier site is physical heterogeneity within the aquifer (DOE 2004). Preferential pathways within the aquifer at the ISRM barrier were identified with flow measurements from the electromagnetic borehole flowmeter (EBF) (Waldrop and Waldrop 2004). Groundwater flowing through these preferential pathways can flush oxygenated waters through the ISRM treatment zone, reducing the reductive capacity of the aquifer. It was recognized that the aquifer heterogeneity needed to be characterized to improve the understanding of depth-discrete variability in physical properties (e.g., hydraulic conductivity). The Technical Assistance Panel identified the electromagnetic borehole flowmeter as one of the tools appropriate for performing the recommended aquifer characterization study.

The primary goal of this work is to characterize the distribution of vertical flow conditions and inferred vertical hydraulic-conductivity distribution in the aquifer targeted for injection of MZVI. Electromagnetic borehole flowmeter surveys are effective for measuring the vertical groundwater-flow velocity distribution in wells. The vertical profile of groundwater-flow velocity measurements within wells can be used to infer the lateral groundwater in-flow distribution at the well location. The objective of EBF surveys is to determine the vertical profile of hydraulic conductivity within well-screened aquifer sections by measuring ambient (i.e., static) and dynamic (i.e., pump-induced) in-well vertical flow (i.e., vertical flow-velocity magnitude and direction).

This report provides a description and quantitative analysis results for EBF surveys that were performed in 10 wells at the ISRM barrier in 2007. The ISRM barrier is located at the U.S. Department of Energy's (DOE's) 100-D Area, Hanford Site, Washington. Figure 3.1 shows a map of the 10 ISRM barrier wells surveyed by the EBF. Previous EBF surveys were performed in ISRM barrier wells in 2004 (Waldrop and Waldrop 2004). The purpose of these previous surveys was to determine the flow patterns and the profiles of hydraulic conductivity for 66 wells tested at the ISRM barrier. 


\subsection{Electromagnetic Borehole Flowmeter Survey Description}

The theory that governs the operation of the EBF is Faraday's Law of Induction, which states that the voltage induced by a conductor moving orthogonally through a magnetic field is directly proportional to the velocity of the conductor moving through the field. For EBF surveys, flowing water is the conductor, an electromagnet generates a magnetic field, and the electrodes within the flowmeter are used to measure the induced voltage. For sign convention, upward flow represents a positive voltage signal, and downward flow represents a negative voltage signal. A more detailed description of the EBF instrument system and field test applications are provided in Molz et al. (1994) and Young et al. (1998).

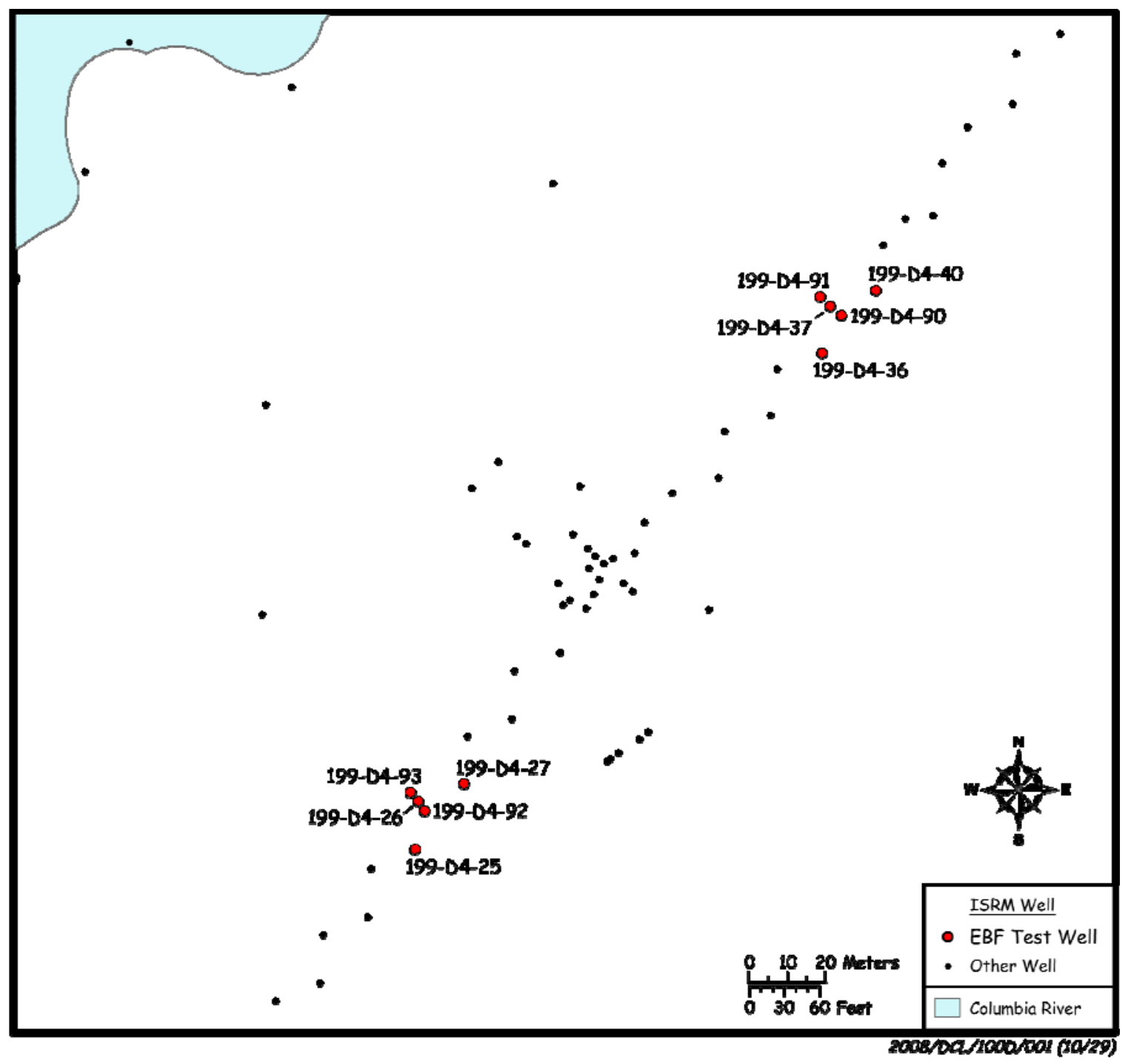

Figure 3.1. Map of ISRM Wells Surveyed by the Electromagnetic Borehole Flowmeter 
A schematic depiction of the field, well-test design is shown in Figure 3.2. The EBF probe consisted of an electromagnet and two electrodes 180 degrees apart inside a hollow cylinder. The inside diameter of the hollow cylinder was $2.5 \mathrm{~cm}$ (1 in.), and the outside diameter of the probe cylinder was just under $5.1 \mathrm{~cm}$ (2.0 inches). The probe was connected to an electronics box at the surface with a jacketed cable. The electronics attached to the electrodes transmit a voltage signal directly proportional to the velocity of water acting as the conductor. Computer software was used to record the voltage signal and convert the signal to a flow-rate measurement.

The manufacturer of the EBF used for the surveys is Quantum Engineering Corporation (Serial Number FMT0205). This EBF probe is capable of measuring flow ranging from 0.04 to $40 \mathrm{~L} / \mathrm{min}$ (0.01 to $10.6 \mathrm{gpm})$.

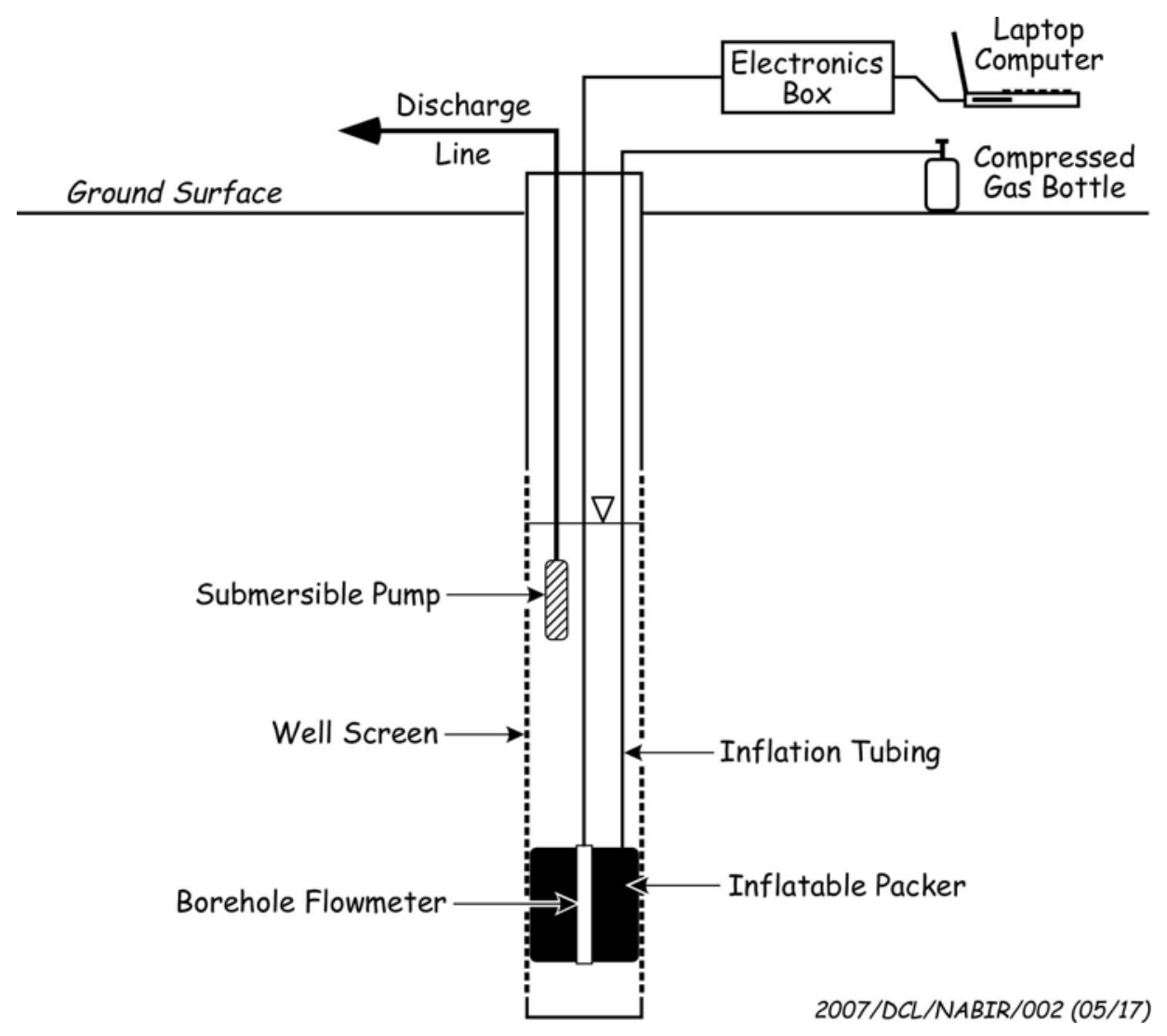

Figure 3.2. General Electromagnetic Borehole Flowmeter Configuration

For stainless steel wire-wrap screens, an inflatable packer was used to minimize bypass flow between the packer and the well screen. The inflatable packer consisted of a rubber sleeve attached to a stainless steel assembly and was sealed with hose clamps or metal bands. The EBF probe cylinder was mounted inside the stainless steel assembly. The packer and all fittings were checked for gas leaks at the surface before flowmeter profiling began. At each prescribed depth, inflation of the packer was controlled with compressed nitrogen gas, a regulator, and inflation tubing. After inflating the packer, the packer seal was checked by pulling the cable for tension. Flow conditions were allowed to re-establish for several minutes because of disturbances caused by movement of the packer/probe assembly. After recording the flow measurement, the packer was deflated with a vented valve. Following packer deflation, the probe was raised (or lowered) very slowly to the next depth, and the measurement procedure was repeated. 
For smaller wells completed with polyvinyl chloride (PVC) well screens, the inflatable-packer-based EBF system could not be used because of equipment size restrictions (i.e., part greater than the 9.2-cm [3-5/8-in.] inside diameter of the PVC casing). For these smaller PVC well-screen completions, a rubbergasket-based EBF system was used to minimize bypass flow between the probe and the well screen. A rubber gasket with a diameter equal to the inside diameter of the Schedule 80 PVC casing (i.e., $9.2 \mathrm{~cm}$ [3-5/8 in.]) was the only option to use to access the $10.2 \mathrm{~cm}$ (4-in.) inside diameter well screen. The rubber gasket was attached to the stainless-steel assembly, which houses the EBF probe cylinder. At each prescribed depth within the well screen, flow conditions were allowed to re-establish for several minutes because of disturbances caused by movement of the gasket/probe system. Since the diameter of the rubber gasket was slightly less than the diameter of the well screen, it was expected that some in-well groundwater-flow bypass would occur between the gasket and the well screen during the flowmeter surveys. This un-measured flow bypass, however, is assumed to be relatively constant or proportional to measured vertical flow within the EBF probe. 


\subsection{Data Acquisition and Reporting}

The EBF surveys were performed by the author, Darrell Newcomer of Pacific Northwest National Laboratory. Jason Modrell of MSE Technology Applications, Inc. provided oversight and assistance during testing and served as the point of contact with Fluor Hanford, Inc.

Both ambient (i.e., static) and dynamic (i.e., pumping-induced) flowmeter tests were performed in 10 wells at the ISRM site facility. The wells tested are listed in Table 4.1. Flowmeter data were acquired at $0.3-\mathrm{m}(1-\mathrm{ft})$ depth intervals over the saturated well-screen sections and at known depth locations of well-screen joints (i.e., casing blank sections). The locations of the well-screen joints were based on well completion logs (i.e., tubular goods tally). These joints were confirmed in the field by manually sensing the relative resistance during raising and lowering of the probe. Measuring vertical groundwater flow at the well-screen joints provides a means for correcting for bypass flow between the packer/probe system and well screen for the data analysis. All flowmeter measurements were referenced to the top of the outer protective casing and then corrected to ground surface for the analyses.

Table 4.1. Summary of Pertinent Well Information

\begin{tabular}{|c|c|c|c|c|c|}
\hline $\begin{array}{l}\text { Well } \\
\text { Number }\end{array}$ & $\begin{array}{c}\text { Pre-Survey } \\
\text { Static Depth-to- } \\
\text { Water (ft bgs) }\end{array}$ & $\begin{array}{l}\text { Pumping- } \\
\text { Induced Depth- } \\
\text { to-Water (ft bgs) }\end{array}$ & $\begin{array}{l}\text { Measured Depth- } \\
\text { to-Bottom (ft bgs) }\end{array}$ & $\begin{array}{l}\text { Depth-to-Top of } \\
\text { Well-Screen } \\
\text { Section (ft bgs) }\end{array}$ & $\begin{array}{l}\text { Depth-to-Bottom } \\
\text { of Well-Screen } \\
\text { Section (ft bgs) }\end{array}$ \\
\hline 199-D4-25 & 80.75 & 81.29 & 99.4 & 84.0 & 99.0 \\
\hline 199-D4-26 & 81.11 & 81.22 & 100.4 & 85.0 & 100.0 \\
\hline 199-D4-27 & 81.75 & 81.91 & 100.4 & $85.0^{(\mathrm{a})}$ & $100.0^{(\mathrm{a})}$ \\
\hline 199-D4-36 & 81.66 & 81.90 & 96.9 & 81.3 & 96.3 \\
\hline 199-D4-37 & 81.70 & 81.75 & 98.1 & $82.6^{(\mathrm{a})}$ & $97.6^{(\mathrm{a})}$ \\
\hline 199-D4-40 & 81.76 & 81.78 & 97.9 & 81.7 & 97.0 \\
\hline 199-D4-90 & 81.25 & 81.38 & 99.8 & $82.8^{(\mathrm{a})}$ & $97.8^{(\mathrm{a})}$ \\
\hline 199-D4-91 & 81.19 & 81.34 & 99.4 & 77.0 & 97.0 \\
\hline 199-D4-92 & 81.25 & 81.59 & 103.3 & 83.0 & 103.0 \\
\hline 199-D4-93 & 80.56 & 80.75 & 102.6 & 82.2 & 102.2 \\
\hline
\end{tabular}

(a) Depth of screen was adjusted, based on the observed depth-to-bottom measurement, which was greater than the depth-to-bottom documented in well logs.

During the dynamic flowmeter tests, groundwater was pumped from the well and discharged to a portable surface containment tank. The discharge rate was $2.65 \mathrm{~L} / \mathrm{min}(\sim 0.7 \mathrm{gpm})$ for three of the wells tested (i.e., 199-D4-90, 199-D4-91, and 199-D4-92) and 6.06 L/min ( 1.6 gpm) for the remaining seven wells tested. The pumping rate was held constant during each dynamic test. As noted previously by Dinwiddie et al. (1999) and Arnold and Molz (2000), head loss through the 2.5-cm (1-in.) EBF probe can essentially be ignored at pumping rates of $10 \mathrm{~L} / \mathrm{min}(2.6 \mathrm{gpm})$ or less. As part of the pre-survey procedure, each well was pumped for $\sim 15$ minutes to remove fines from the well screen and allow flow to reach near-equilibrium conditions before initiating the EBF survey flow measurements. The discharge rate was measured at the beginning and end of the dynamic tests with a calibrated bucket and stopwatch. 
Flowmeter-measurements were initially made in succession from bottom to top within the saturated well-screen section, which is the standard procedure. It was noted during the beginning of the EBF field test characterization, however, that fine-grained sediment and mud located at the bottom of the wellscreen sections at some wells adhered to the EBF probe, resulting in faulty flowmeter readings. When this occurred, the adhering mud was cleaned from the probe, and the flowmeter survey was repeated with in-well flow measurements progressing from top to bottom within the surveyed well screens. Because of the potential for mud adhering to the probe sensor and causing faulty readings, all later EBF well survey measurements within the remaining wells were conducted in succession from top to bottom. Zero flowpoint measurements taken at the bottom of the well screen also provide a reference for the EBF survey measurements.

All field notes were recorded on EBF Field Data Sheets, according to Procedure Number PNL-MA-567 AT-9, Rev. 0, Electromagnetic Borehole Flowmeter Survey. All electronic data were recorded to comma-delimited file format on a laptop computer and were analyzed using spreadsheet file format. Well completion log information is provided in Appendix A. 


\subsection{Electromagnetic Borehole Flowmeter Calibration}

The EBF probe was calibrated according to the manufacturer's calibration procedure described in Young et al. (1998) before field testing. The instrument was calibrated over a range of flow rates comparable to flow rates used in the field. The calibration procedure consisted of establishing a constant uniform flow rate through a vertical PVC pipe containing the EBF probe and comparing the flowmeter measurements (in voltage output) with flow-rate measurements at the PVC pipe outlet. Flow rates were maintained at a constant rate with a power supply box with a controller and a 12-volt pump. A linear regression plot of the calibration measurements yielded a calibration factor of $3.833 \mathrm{LPM} / \mathrm{volt}$ (1.013 gpm/volt) (Figure 5.1).

\section{EBF Calibration, FMT0205, 5-18-07 \\ Meter Factor 248}

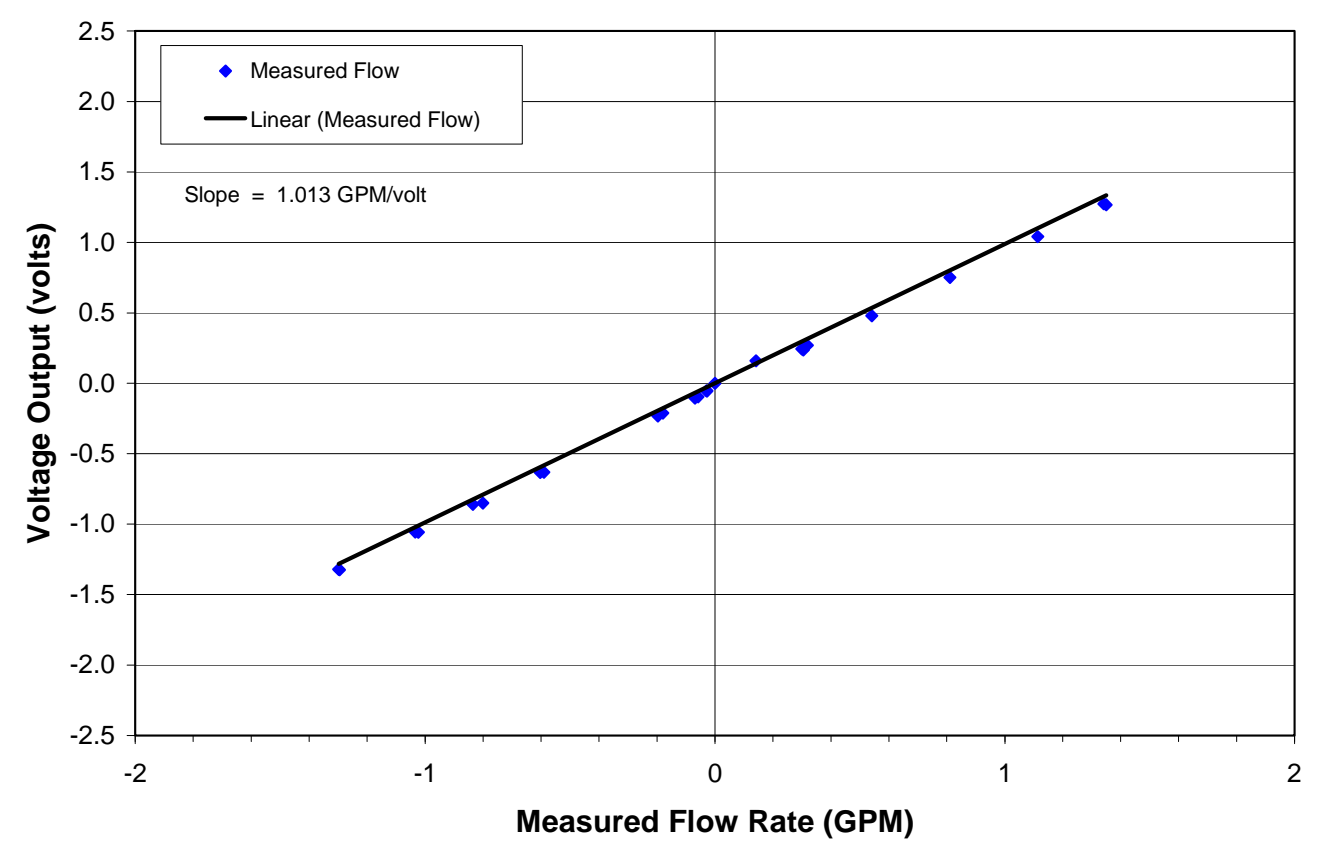

Figure 5.1. Electromagnetic Borehole Flowmeter Calibration Results 


\subsection{Electromagnetic Borehole Flowmeter Survey Analyses}

A technical analysis of EBF tests assumes that the aquifer within the surveyed well-screen section is composed of a series of $n$ horizontal layers. Under ambient-flow conditions, the difference between two successive flowmeter measurements is the portion of ambient flow, $\Delta \mathrm{q}_{\mathrm{i}}$, entering the well screen between depths where the flow measurements were taken. These two depths are assumed to bound interval $i$ $(I=1,2, \ldots, n)$. The portion of flow, $\Delta \mathrm{Q}_{\mathrm{i}}$, entering the well screen between these successive depths under pump-induced conditions is calculated in the same manner.

The data-analysis method used for calculating the vertical distribution of relative hydraulic conductivity is summarized by Molz and Young (1993) and is based on relationships reported in Javandel and Witherspoon (1969). Assuming that a constant pumping rate and pseudo-steady-state conditions are reached, the normalized relative hydraulic conductivity, $\mathrm{K}_{\mathrm{r}}$, for each ith interval can be calculated as follows:

$$
K_{r}=\frac{K_{i}}{K_{\text {avg }}}=\frac{\left(\Delta Q_{i}-\Delta q_{i}\right) / \Delta z_{i}}{\sum_{i}\left(\Delta Q_{i}-\Delta q_{i}\right) / \sum z_{i}} ; i=1,2, \ldots, n
$$

where $\quad \mathrm{K}_{\mathrm{i}}=$ Absolute horizontal hydraulic conductivity of the $i^{\text {th }}$ layer

$\mathrm{K}_{\mathrm{avg}}=$ Average horizontal hydraulic conductivity

$\Delta \mathrm{Q}_{\mathrm{i}}=$ Difference in EBF flow measurements at the top and bottom of the $i^{\text {th }}$ interval under pumping conditions

$\Delta \mathrm{q}_{\mathrm{i}}=$ Difference in EBF flow measurements at the top and bottom of the $i^{\text {th }}$ interval under ambient conditions

$\Delta \mathrm{z}_{\mathrm{i}}=$ ith interval thickness.

As indicated in Equation (1), the normalized relative hydraulic-conductivity value can be determined directly by measuring specific depth inflow rates as it relates to total flow pumped from the entire test interval. An absolute or actual depth profile of hydraulic-conductivity values (i.e., $\mathrm{K}_{\mathrm{i}}$ versus depth), however, can be developed if an estimate of $\mathrm{K}_{\text {avg }}$ has been determined from a standard hydrologic test method (e.g., constant-rate pumping test). This can be derived by calculating the dimensional values of $\mathrm{K}_{\mathrm{i}}$ for each $i^{\text {th }}$ depth interval by multiplying the net relationship indicating the results of testing dynamic flowmeter discharges (indicated in Equation [1]) by the previously determined $\mathrm{K}_{\mathrm{avg}}$ value.

It should be noted that this analysis method is strictly valid for EBF surveys conducted within confined aquifers. For EBF surveys conducted within fully penetrating unconfined aquifer wells where transmissivity conditions are relatively high, however, adverse boundary effects associated with flow convergence (i.e., non-horizontal flow) at the water table are considered to be negligible. In these situations, the $\mathrm{K}_{\mathrm{r}}$ relationship expressed in Equation (1) is considered valid for unconfined aquifer characterization. The EBF characterization method was considered to be applicable for the fully 
penetrating unconfined wells tested, which are completed within high-permeable sediments of the Ringold Formation at the Zero-Valent Iron Site (WMP-26460, Rev. 0). In addition, boundary flowconvergence effects were minimized during EBF testing by using low pumping discharge rates, which produced small water-table drawdowns ranging from 0.006 to $0.17 \mathrm{~m}(0.02$ to $0.55 \mathrm{ft})$.

When performing EBF dynamic surveys in wire-wrap screens, it is not possible to obtain a perfect seal between the probe and the screen because of longitudinal spacer ribs lining the inside of the screen. Consequently, the EBF probe can only measure a percentage of the total inflow that enters the screen from below the EBF probe and moves vertically up the wellbore. However, at the joint between two well-screen sections where the inner wall is blank casing, a perfect seal is obtained, and all flow entering the screen below the EBF is forced upward through the probe. This typically results in a higher EBF flow reading at the joint compared to flow measurements above and below the joint. To account and correct for bypass flow resulting from an imperfect seal, the EBF flow measurements were multiplied by a ratio between the measured flow at the screen joint and a flow value interpolated for the depth of the screen joint using flow readings immediately above and below the joint.

Bypass flow can also occur through the artificial sand-pack material surrounding the well screen during EBF dynamic surveys (Boman et al. 1997). A fraction of the flow to the well moves vertically up the sand-pack material and enters the screen above the EBF probe. However, all flow entering the screen must pass through the EBF probe within the well casing above the screen. To correct for bypass flow through the sand-pack material, the EBF flow measurements were multiplied by a ratio between the measured flow within the well casing and a flow value estimated for the same well-casing depth. The estimated flow value is calculated by applying a slope through the measured flow readings within the upper part of the well-screen test-interval section. 


\subsection{Electromagnetic Borehole Flowmeter Survey Results}

Ambient and dynamic EBF surveys were performed in 10 wells at the ISRM barrier site. A summary of the pertinent well information is provided in Table 4.1. The following sections describe the flowmeter survey performed at each well and analysis results for the well-screen sections profiled. All depths in the following sections are referenced to ground surface. A summary of the well screen inside diameter and materials, EBF surveys performed, and discharge rates is provided in Table 7.1. More detailed information regarding the well construction for four of the wells surveyed with the EBF (199-D4-90, 199-D4-91, 199-D4-92, and 199-D4-93) can be found in WMP-26460 (2005). A summary of the EBF analysis data is provided in Appendix B.

Table 7.1. Summary of EBF Survey Information

\begin{tabular}{|c|c|c|c|c|c|c|}
\hline \multirow[b]{2}{*}{$\begin{array}{c}\text { Well } \\
\text { Number }\end{array}$} & \multirow[b]{2}{*}{ Date of Test } & \multirow{2}{*}{$\begin{array}{c}\text { Well Screen } \\
\text { Inside Diameter } \\
\text { (in.) }\end{array}$} & \multirow[b]{2}{*}{ Well Screen Type } & \multicolumn{3}{|c|}{ Types of EBF Tests Performed } \\
\hline & & & & Ambient & Dynamic & $\begin{array}{l}\text { Discharge } \\
\text { Rate (gpm) }\end{array}$ \\
\hline 199-D4-25 & $5 / 29 / 2007$ & 6 & Stainless steel wire-wrap & $\mathrm{X}$ & $\mathrm{X}$ & 1.58 \\
\hline 199-D4-26 & $5 / 24 / 2007$ & 6 & Stainless steel wire-wrap & $\mathrm{X}$ & $\mathrm{X}$ & 1.57 \\
\hline 199-D4-27 & $5 / 24 / 2007$ & 6 & Stainless steel wire-wrap & $\mathrm{X}$ & $\mathrm{X}$ & 1.58 \\
\hline 199-D4-36 & $5 / 22-23 / 2007$ & 6 & Stainless steel wire-wrap & $\mathrm{X}$ & $\mathrm{X}$ & 1.52 \\
\hline 199-D4-37 & $5 / 22-23 / 2007$ & 6 & Stainless steel wire-wrap & $\mathrm{X}$ & $\mathrm{X}$ & 1.65 \\
\hline 199-D4-40 & $5 / 23 / 2007$ & 6 & Stainless steel wire-wrap & $\mathrm{X}$ & $\mathrm{X}$ & 1.66 \\
\hline 199-D4-90 & $5 / 30 / 2007$ & 4 & Stainless steel wire-wrap & $\mathrm{X}$ & $\mathrm{X}$ & 0.72 \\
\hline 199-D4-91 & $5 / 30 / 2007$ & $4^{(a)}$ & V-wire wrap PVC Screen & $\mathrm{X}$ & $\mathrm{X}$ & 0.74 \\
\hline 199-D4-92 & $6 / 4 / 2007$ & $4^{(a)}$ & V-wire wrap PVC Screen & $\mathrm{X}$ & $\mathrm{X}$ & 0.72 \\
\hline 199-D4-93 & $5 / 29 / 2007$ & 4 & Stainless steel wire-wrap & $\mathrm{X}$ & $\mathrm{X}$ & 1.61 \\
\hline
\end{tabular}

(a) Schedule 80 PVC casing inside diameter is $9.2 \mathrm{~cm}(35 / 8$ in. $)$.

For dynamic EBF surveys where the water table was within the well-screen section, an average depth to water between the static depth to water and pump-induced depth to water (i.e., drawdown) was assigned for the upper boundary of the test interval. However, flow measurements could not be obtained in the upper few feet of the test interval because of the presence of the submersible pump. Because of this, the test interval analyzed for relative hydraulic conductivity for these cases was less than the actual interval tested in the field, and relative hydraulic conductivity was not assigned to these upper few feet of the well-screen section.

\subsection{Well 199-D4-25}

Well 199-D4-25 was completed with a 4.6-m (15-ft) long, 15.2-cm (6-in.) inside diameter stainless steel wire-wrap screen at a depth of 25.6 to $30.2 \mathrm{~m}(84.0$ to $99.0 \mathrm{ft}) \mathrm{bgs}$. The screen has a solid joint at a depth of $27.2 \mathrm{~m}(89.2 \mathrm{ft}) \mathrm{bgs}$, and a $0.1-\mathrm{m}(0.4-\mathrm{ft})$ cap was attached below the bottom of the well-screen 
section. The measured static depth to water before beginning the flowmeter surveys was $24.6 \mathrm{~m}(80.8 \mathrm{ft})$ bgs, which is above the top of the well-screen section. The well summary log (Figure A.1) indicates that the well-screen test interval consists of silty sandy gravel.

Ambient and dynamic flowmeter surveys were performed on May 29, 2007, between approximately 0800 and 1130 PST. Vertical flow was measured in succession from top to bottom, beginning at a depth of $25.6 \mathrm{~m}(84 \mathrm{ft})$ bgs within the casing above the top of the well screen and ending in the cap near the bottom of the well at a depth of $30.2 \mathrm{~m}(99.2 \mathrm{ft}) \mathrm{bgs}$, a point of zero flow. During the dynamic survey, the flow rate measured by the EBF within the well casing above the top of the well-screen section was $5.64 \mathrm{~L} / \mathrm{min}(1.49 \mathrm{gpm})$, which is $\sim 5 \%$ lower than the constant discharge rate of $5.98 \mathrm{~L} / \mathrm{min}(1.58 \mathrm{gpm})$ measured at the surface. However, this is within the range of error (i.e., up to $\sim 10 \%$ ) for the EBF flow measurements.

The ambient and dynamic vertical flow profiles are shown in Figure 7.1. The ambient vertical flow profile indicates low, but measurable, upward flow over the saturated well-screen section. The measured net flow profile (i.e., induced minus ambient flow) indicates an increase in measured flow at the solid screen joint at a depth of $27.2 \mathrm{~m}(89.2 \mathrm{ft}) \mathrm{bgs}$. This increase in measured flow suggests that vertical bypass flow occurred between the inflated packer and the well screen. The net flow was corrected for this bypass flow by multiplying the net flow by a correction factor of 1.19 . This correction factor represents the ratio between the measured flow at the screen joint and a flow value interpolated for this depth using measured values immediately above and below the joint.

An abrupt increase in measured vertical flow within the well casing above the top of the well-screen section (i.e., difference between corrected net flow and measured flow) suggests that vertical bypass flow also occurred through the sand pack material adjacent to the well-screen section. An additional correction was applied to the net flow by a factor of 1.50 , which represents the ratio between the measured flow within the well casing and a flow value estimated for this depth by applying a slope through measured flow values within the upper part of the well-screen section. A comparison of the measured net flow and the net flow corrected for total bypass indicates that $45 \%$ of the flow bypassed the flowmeter, with $\sim 12 \%$ of flow bypassing between the inflated packer and the well screen and $\sim 33 \%$ of flow bypassing through the sand pack material adjacent to the well screen.

The net flow profile corrected for total bypass flow was used to calculate normalized hydraulic conductivity. The profile of normalized hydraulic conductivity, presented in Figure 7.2, indicates a generally uniform distribution of relative hydraulic conductivity within the well-screen section. An exception is a slightly higher relative hydraulic conductivity of 0.16 between a depth of 92 and $93 \mathrm{ft}$ (28.0 and $28.3 \mathrm{~m})$ bgs. 


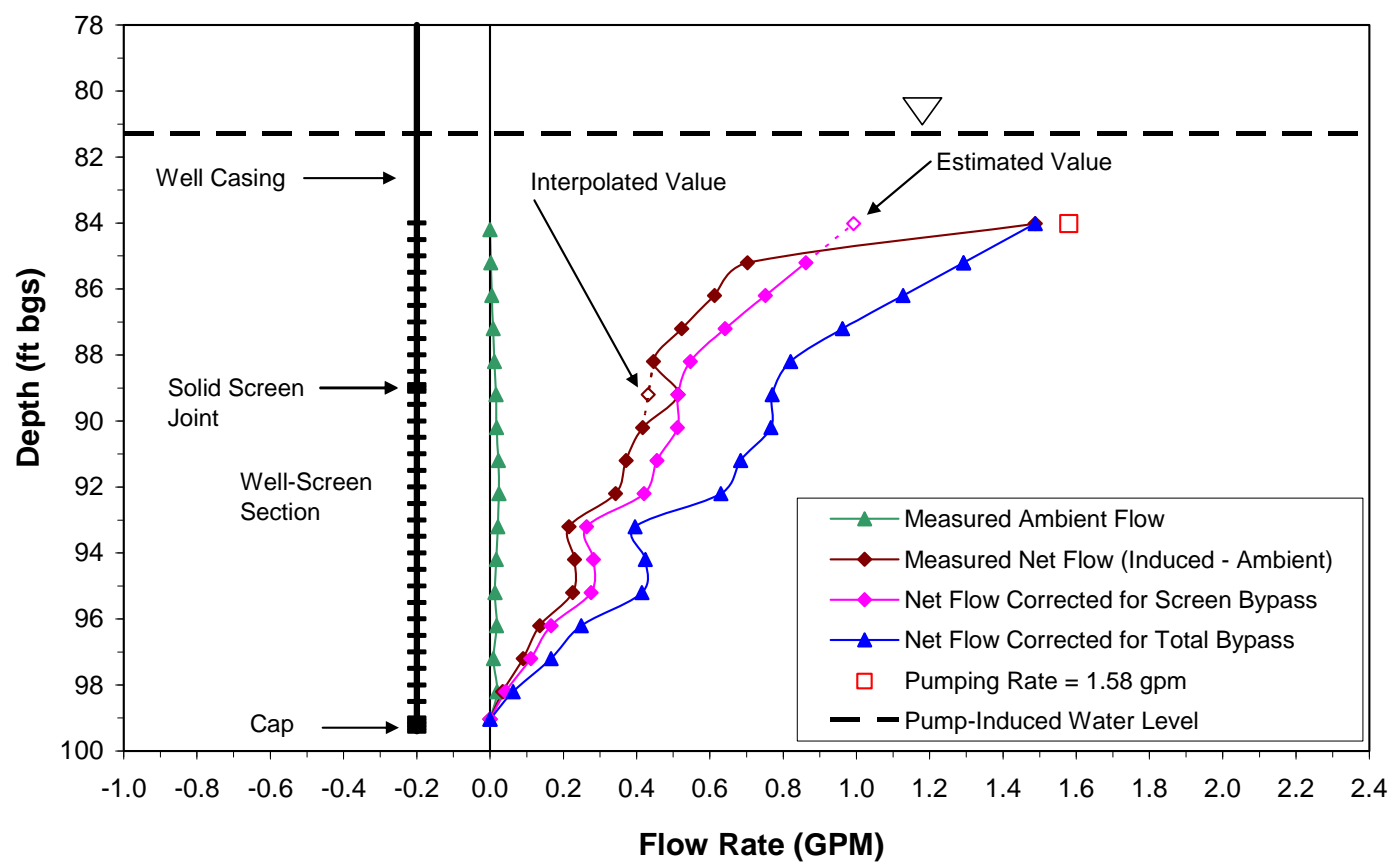

Figure 7.1. Ambient and Dynamic Vertical Flow Profiles, Well 199-D4-25

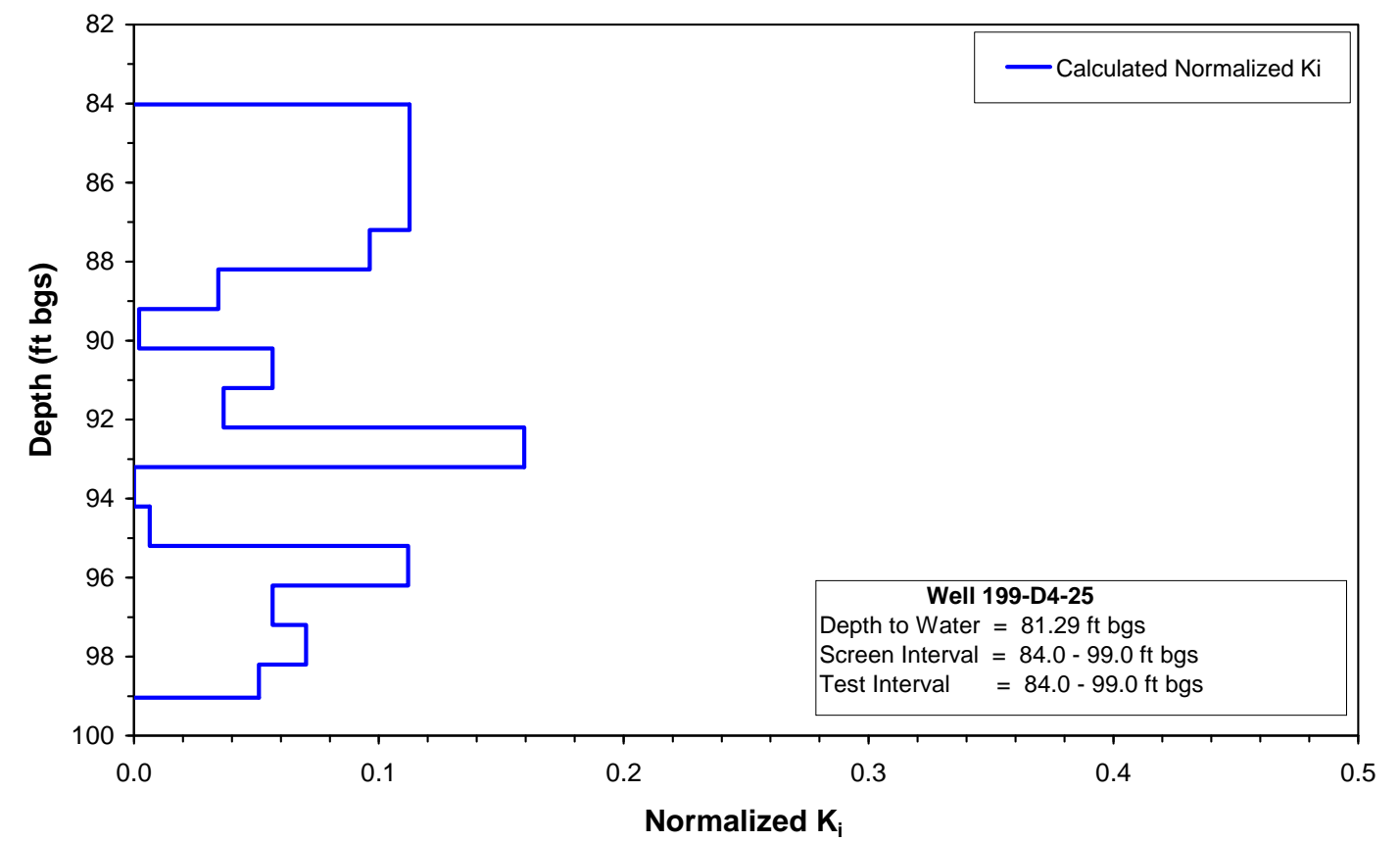

Figure 7.2. Relative Hydraulic Conductivity Profile, Well 199-D4-25 


\subsection{Well 199-D4-26}

Well 199-D4-26 was completed with a 4.6-m (15-ft) long, 15.2-cm (6-in.) inside diameter stainless steel wire-wrap screen at a depth of 25.9 to $30.5 \mathrm{~m}(85.0$ to $100.0 \mathrm{ft}) \mathrm{bgs}$. The screen has a solid joint at a depth of $27.4 \mathrm{~m}(90.0 \mathrm{ft})$, and a $0.1-\mathrm{m}(0.4-\mathrm{ft})$ cap was attached below the bottom of the well-screen section. The measured static depth to water before beginning the flowmeter surveys was $24.7 \mathrm{~m}(81.1 \mathrm{ft})$ bgs, which is above the top of the well-screen section. The well summary log (Figure A.2) indicates that the well-screen test interval consists of sandy gravel.

Ambient and dynamic flowmeter surveys were performed on May 24, 2007, between approximately 0800 and 1200 PST. Vertical flow was measured in succession from top to bottom, beginning at a depth of $25.5 \mathrm{~m}(83.6 \mathrm{ft})$ within the casing above the top of the well screen and ending in the cap at the bottom of the well at a depth of $30.6 \mathrm{~m}(100.4 \mathrm{ft})$, a point of zero flow. During the dynamic survey, the flow rate measured by the EBF within the well casing above the top of the well-screen section was $5.53 \mathrm{~L} / \mathrm{min}$ (1.46 gpm), which is $\sim 7 \%$ lower than the constant discharge rate of $5.94 \mathrm{~L} / \mathrm{min}(1.57 \mathrm{gpm})$ measured at the surface. However, this is within the range of error (i.e., up to $10 \%$ ) for the EBF flow measurements.

The ambient and dynamic vertical flow profiles are shown in Figure 7.3. The ambient vertical flow profile indicates measurable upward flow of $0.38 \mathrm{~L} / \mathrm{min}(0.10 \mathrm{gpm})$ over the saturated well-screen section. The measured net flow profile (i.e., induced minus ambient flow) indicates an increase in measured flow at a depth of $27.9 \mathrm{~m}(91.6 \mathrm{ft}) \mathrm{bgs}$, just below the solid screen joint. The cause of this discrepancy is unknown. The increase in measured flow suggests that vertical bypass flow occurred between the inflated packer and the well screen. The net flow was corrected for this bypass flow by multiplying the net flow by a correction factor of 1.63. This correction factor represents the ratio between the measured flow at the screen joint and a flow value interpolated for this depth using measured values immediately above and below the joint.

An abrupt increase in measured vertical flow values near and above the top of the well-screen section (i.e., difference between corrected net flow and measured flow) suggests that vertical bypass flow also occurred through the sand pack material adjacent to the well-screen section. An additional correction was applied to the net flow by a factor of 1.37 , which represents the ratio between the measured flow within the well casing and a flow value estimated for this depth by applying a slope through measured flow values within the upper part of the well-screen section. A comparison of the measured net flow and the net flow corrected for total bypass indicates that $\sim 55 \%$ of the flow bypassed the flowmeter, with $\sim 28 \%$ of flow bypassing between the inflated packer and the well screen and $\sim 27 \%$ of flow bypassing through the sand pack material adjacent to the well screen. The abrupt increase in measured dynamic flow at a depth of $26.4 \mathrm{~m}(86.6 \mathrm{ft}) \mathrm{bgs}$ (and the ambient profile) suggests that the top of the screen may be near this depth, not at $26 \mathrm{~m}(85.0 \mathrm{ft}) \mathrm{bgs}$ as shown by the well log. Because of this, a test interval of 26.4 to $30.5 \mathrm{~m}$ (86.6 to $100.0 \mathrm{ft}$ ) bgs was used for calculating normalized hydraulic conductivity. 


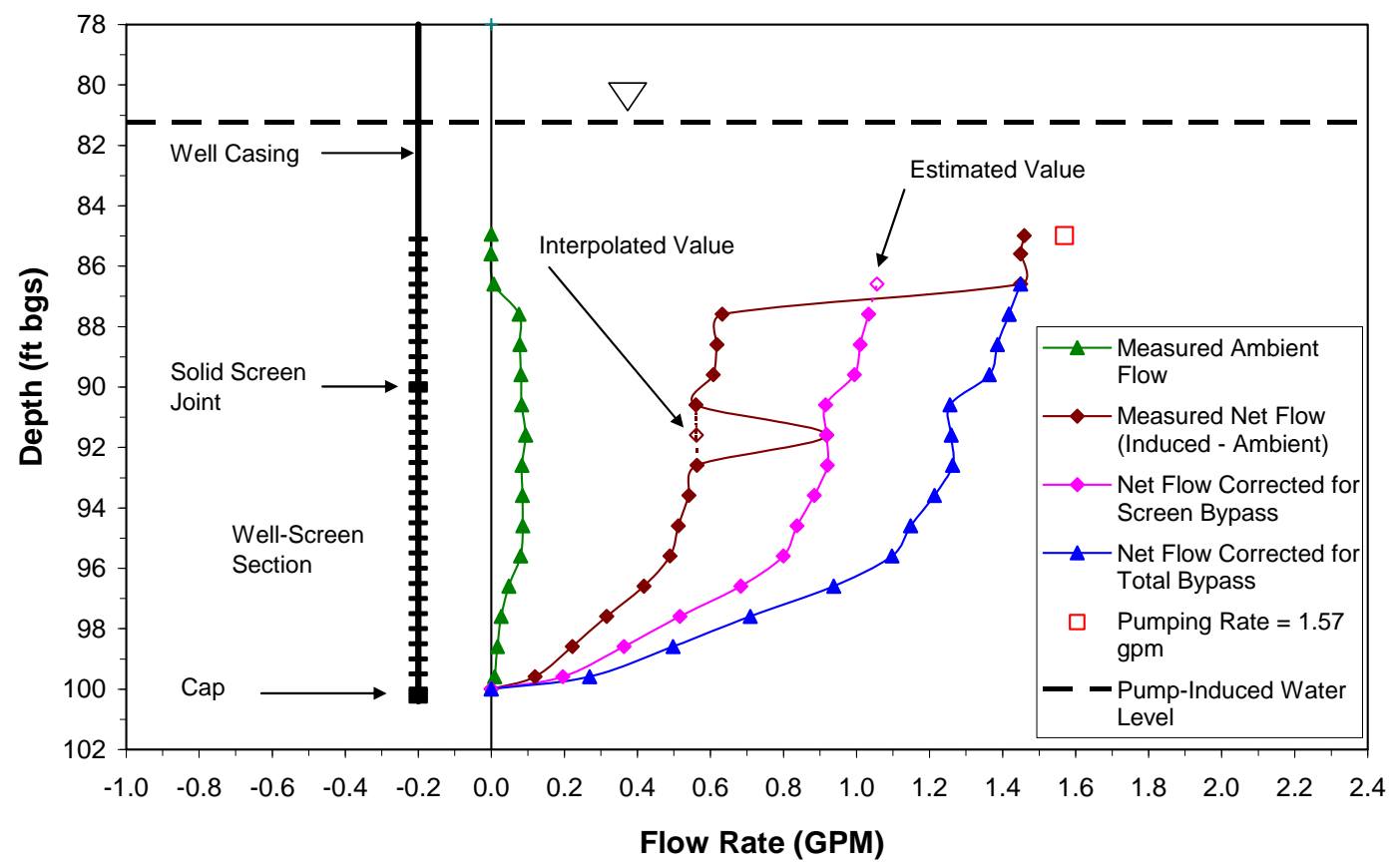

Figure 7.3. Ambient and Dynamic Vertical Flow Profiles, Well 199-D4-26

The net flow profile corrected for total bypass flow was used to calculate normalized hydraulic conductivity. The profile of normalized hydraulic conductivity, presented in Figure 7.4, generally indicates increasing relative hydraulic conductivity with depth. A significantly higher normalized $\mathrm{K}_{\mathrm{i}}$ of 0.36 occurs within the bottom $0.1 \mathrm{~m}(0.4 \mathrm{ft})$ of the test interval.

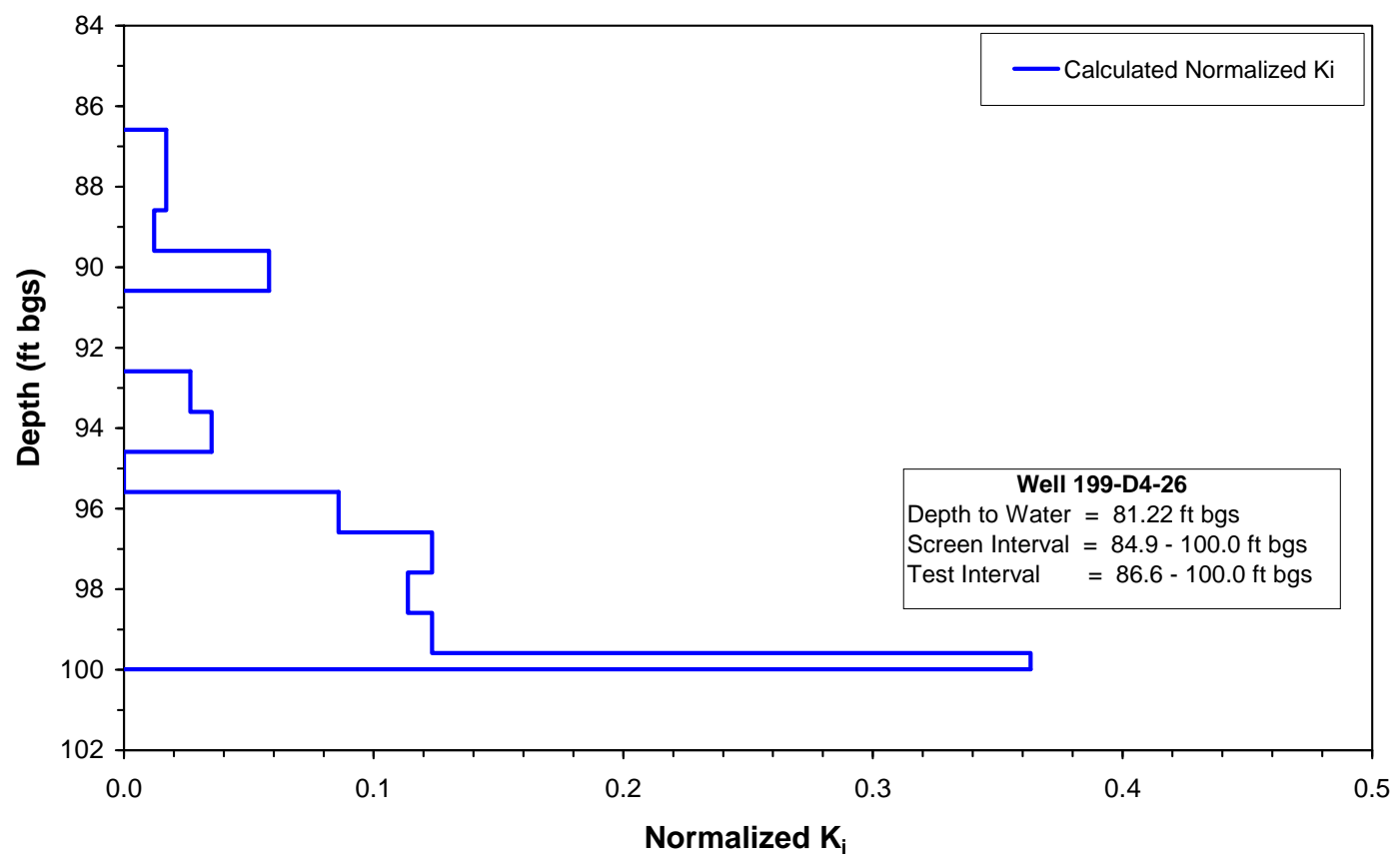

Figure 7.4. Relative Hydraulic Conductivity Profile, Well 199-D4-26 


\subsection{Well 199-D4-27}

Well 199-D4-27 was completed with a 4.6-m (15-ft) long, 15.2-cm (6-in.) inside diameter stainless steel wire-wrap screen at a depth of 25.9 to $30.5 \mathrm{~m}(85.0$ to $100.0 \mathrm{ft}) \mathrm{bgs}$. The screen has a solid joint at a depth of $29.0 \mathrm{~m}(95.0 \mathrm{ft}) \mathrm{bgs}$, and a $0.1-\mathrm{m}(0.4-\mathrm{ft})$ cap was attached below the bottom of the well-screen section. The measured static depth to water before beginning the flowmeter surveys was $24.9 \mathrm{~m}(81.8 \mathrm{ft})$ bgs, which is above the top of the well-screen section. The well summary log (Figure A.3) indicates that the well-screen test interval consists of sandy gravel.

Ambient and dynamic flowmeter surveys were performed on May 24, 2007, between 1230 and 1615 PST. Vertical flow was measured in succession from top to bottom, beginning at a depth of $25.8 \mathrm{~m}$ (84.6 ft) bgs within the casing above the top of the well screen and ending in the cap at the bottom of the well at a depth of $30.6 \mathrm{~m}(100.4 \mathrm{ft}) \mathrm{bgs}$, a point of zero flow. During the dynamic survey, the flow-rate measured by the EBF within the well casing above the top of the well-screen section was $5.64 \mathrm{~L} / \mathrm{min}$ (1.49 gpm), which is $\sim 5 \%$ lower than the constant discharge rate of $5.98 \mathrm{~L} / \mathrm{min}(1.58 \mathrm{gpm})$ measured at the surface. However, this is within the range of error (i.e., up to $10 \%$ ) for the EBF flow measurements.

The ambient and dynamic vertical flow profiles are shown in Figure 7.5. The ambient vertical flow profile indicates measurable upward flow over the saturated well-screen section, with a maximum upward flow of $0.14 \mathrm{gpm}(0.53 \mathrm{~L} / \mathrm{min})$. The measured net flow profile (i.e., induced minus ambient flow) indicates an increase in measured flow at the solid screen joint at a depth of $29.1 \mathrm{~m}(95.6 \mathrm{ft}) \mathrm{bgs}$. The increase in measured flow suggests that vertical bypass flow occurred between the inflated packer and the well screen. The net flow was corrected for this bypass flow by multiplying the net flow by a correction factor of 1.78, which represents the ratio between the measured flow at the screen joint and a flow value interpolated for this depth using measured values immediately above and below the joint. Figure 7.5 shows that the corrected net flow is equivalent to measured flow at the top of the well screen, which suggests that no bypass occurred through the sand pack material. A comparison of the measured net flow and the net flow corrected for bypass indicates that $\sim 44 \%$ of the total flow bypassed the flowmeter between the inflated packer and the well screen.

The profile in Figure 7.5 also indicates a second, lower magnitude increase in measured flow at a depth of $27.3 \mathrm{~m}(89.6 \mathrm{ft}) \mathrm{bgs}$. The tubular goods tally does not document a solid screen joint at this depth, and any resistance while lowering the EBF probe past this depth was not evident during testing.

The net flow corrected for screen bypass was used to calculate normalized hydraulic conductivity. The profile of normalized hydraulic conductivity, presented in Figure 7.6, indicates a zone of high relative hydraulic conductivity at a depth of $\sim 30$ to $30.5 \mathrm{~m}$ ( $\sim 98$ to $100 \mathrm{ft}$ ) bgs and at a depth of $\sim 27 \mathrm{~m}$ ( $\sim 90 \mathrm{ft}$ ) bgs. The distribution of relative hydraulic conductivity within the well-screen section is generally uniform at depths of 25.9 to $27.1 \mathrm{~m}$ ( 85 to $89 \mathrm{ft}$ ) and 27.7 to $29.9 \mathrm{~m} \mathrm{(91} \mathrm{to} 98 \mathrm{ft}$ ) bgs. 


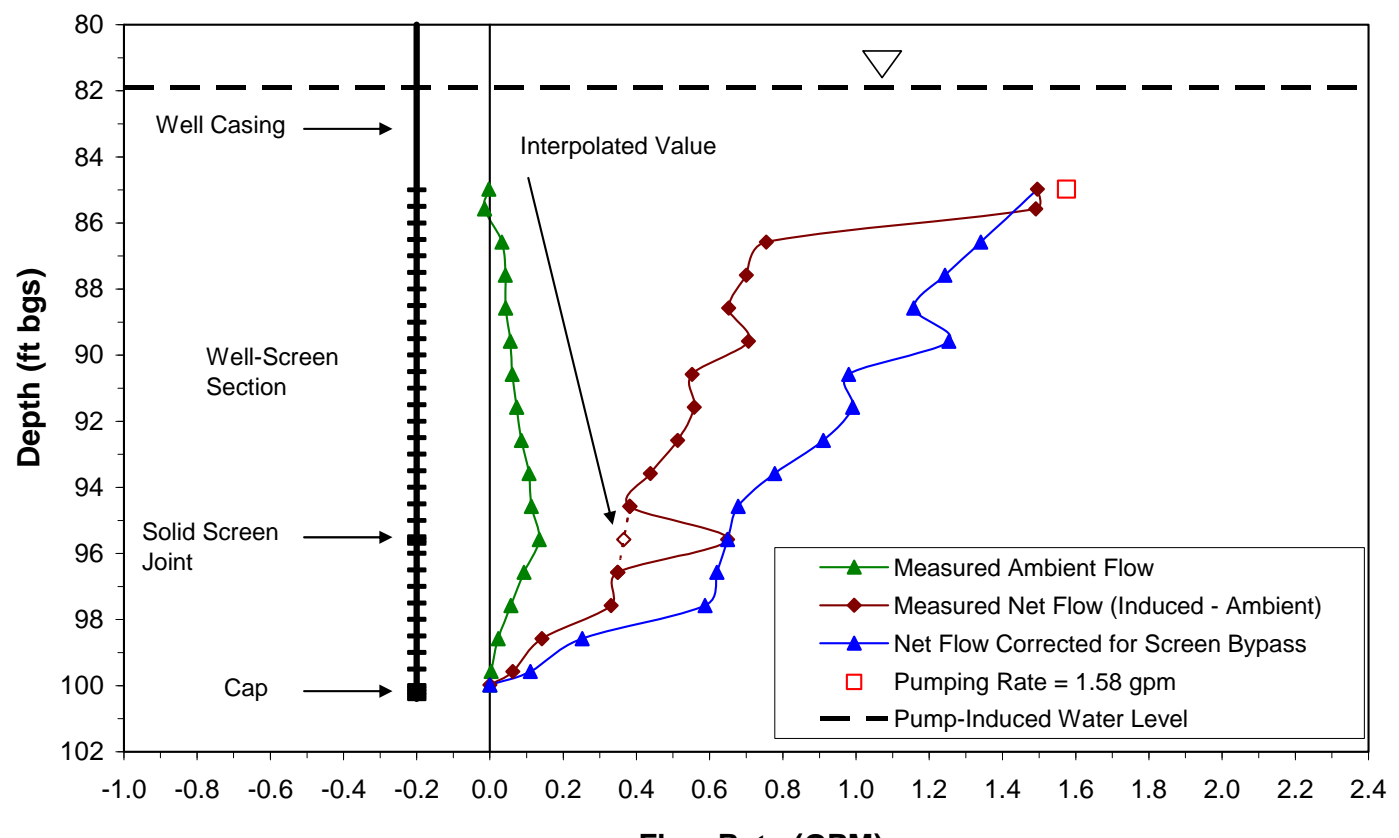

Flow Rate (GPM)

Figure 7.5. Ambient and Dynamic Vertical Flow Profiles, Well 199-D4-27

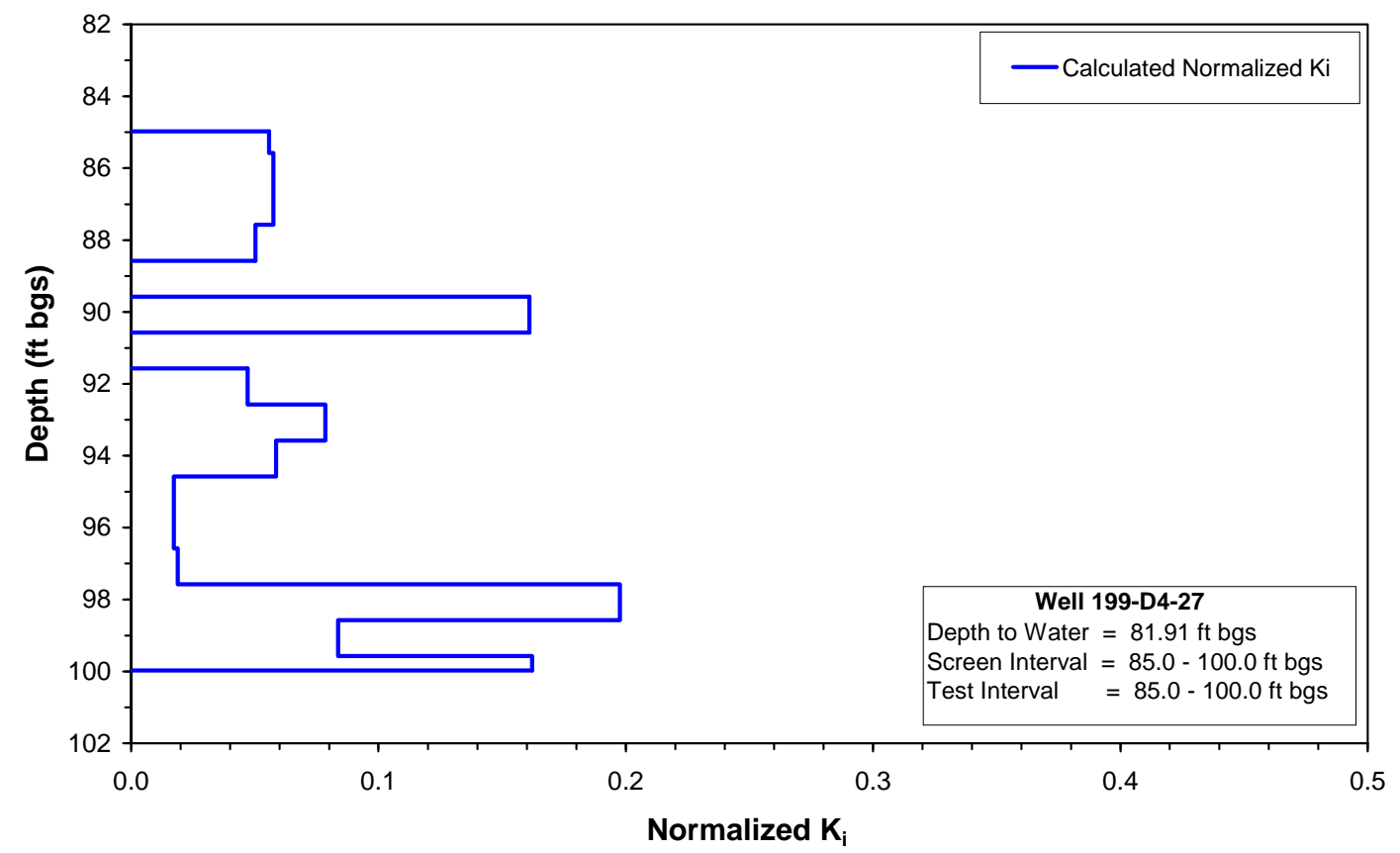

Figure 7.6. Relative Hydraulic Conductivity Profile, Well 199-D4-27 


\subsection{Well 199-D4-36}

Well 199-D4-36 was completed with a 4.6-m (15-ft) long, 15.2-cm (6-in.) inside diameter stainless steel wire-wrap screen at a depth of 24.8 to $29.4 \mathrm{~m}(81.3$ to $96.3 \mathrm{ft}) \mathrm{bgs}$. The screen has a solid joint at a depth of $27.8 \mathrm{~m}(91.3 \mathrm{ft}) \mathrm{bgs}$, and a $0.15-\mathrm{m}(0.5-\mathrm{ft})$ cap was attached below the bottom of the well-screen section. The measured static depth to water before beginning the flowmeter surveys was $24.9 \mathrm{~m}(81.6 \mathrm{ft})$ bgs, which lies near the top of the well-screen section. The well summary log (Figure A.4) indicates that the well-screen test interval consists predominantly of sandy gravel, with sand within the upper $0.9 \mathrm{~m}$ $(2.9 \mathrm{ft})$ of the test interval and silt within the bottom $0.2 \mathrm{~m}(0.6 \mathrm{ft})$ of the test interval.

An ambient flowmeter survey was performed late in the day on May 22, 2007, between approximately 1430 and 1600 PST, and a dynamic flowmeter survey was performed early the next day on May 23, 2007 (between approximately 0900 and 1045 PST), after the portable purge tank arrived. Vertical flow was measured in succession from bottom to top, beginning in the cap at the bottom of the well at a depth of $29.5 \mathrm{~m}(96.8 \mathrm{ft}) \mathrm{bgs}$, the point of zero flow, and ending near the top of the well-screen section at a depth of $25.5 \mathrm{~m}(83.6 \mathrm{ft})$ bgs. The constant discharge rate during the dynamic survey was $5.75 \mathrm{~L} / \mathrm{min}(1.52 \mathrm{gpm})$.

The ambient and dynamic vertical flow profiles are shown in Figure 7.7. The ambient vertical flow profile indicates measurable upward flow over the saturated well-screen section, with a maximum upward flow of $0.38 \mathrm{~L} / \mathrm{min}(0.10 \mathrm{gpm})$. The large difference between measured net flow (i.e., induced minus ambient flow) near the top of the well-screen section and the pumping discharge rate suggests that bypass flow occurred during the dynamic test. The net flow was corrected for bypass flow by multiplying the net flow by a correction factor of 1.91 . This correction factor represents the ratio between the pumping discharge rate and a flow value estimated for the top of the test interval by applying a slope through measured values within the upper part of the well-screen section.

A comparison of the measured net flow and the net flow corrected for bypass indicates that $\sim 48 \%$ of the flow bypassed the flowmeter. Measured dynamic flow at the solid screen joint did not increase relative to measurements above and below the joint, as might be expected. However, considering the dynamic flow at this depth measured low $(\sim 0.8 \mathrm{~L} / \mathrm{min}[\sim 0.2 \mathrm{gpm}])$ and at this low flow range, it is likely that most of the flow passed through the flowmeter orifice. Because of this, the proportion of bypass flow between the inflated packer and the screen and bypass flow through the sand pack material cannot be determined for higher dynamic flows measured above the joint.

The net flow profile corrected for bypass flow was used to calculate normalized hydraulic conductivity. The profile of normalized hydraulic conductivity, presented in Figure 7.8, indicates a zone of high relative hydraulic conductivity at a depth of $\sim 26$ to $28 \mathrm{~m}$ ( $\sim 86$ to $91 \mathrm{ft})$ bgs. The distribution of relative hydraulic conductivity is generally lower within the upper and lower portions of the well-screen test interval at depths of $\sim 25$ to $26 \mathrm{~m}$ ( $\sim 82$ to $86 \mathrm{ft}$ ) bgs and $\sim 28$ to $29 \mathrm{~m}$ ( $\sim 91$ to $96 \mathrm{ft})$ bgs, respectively. 


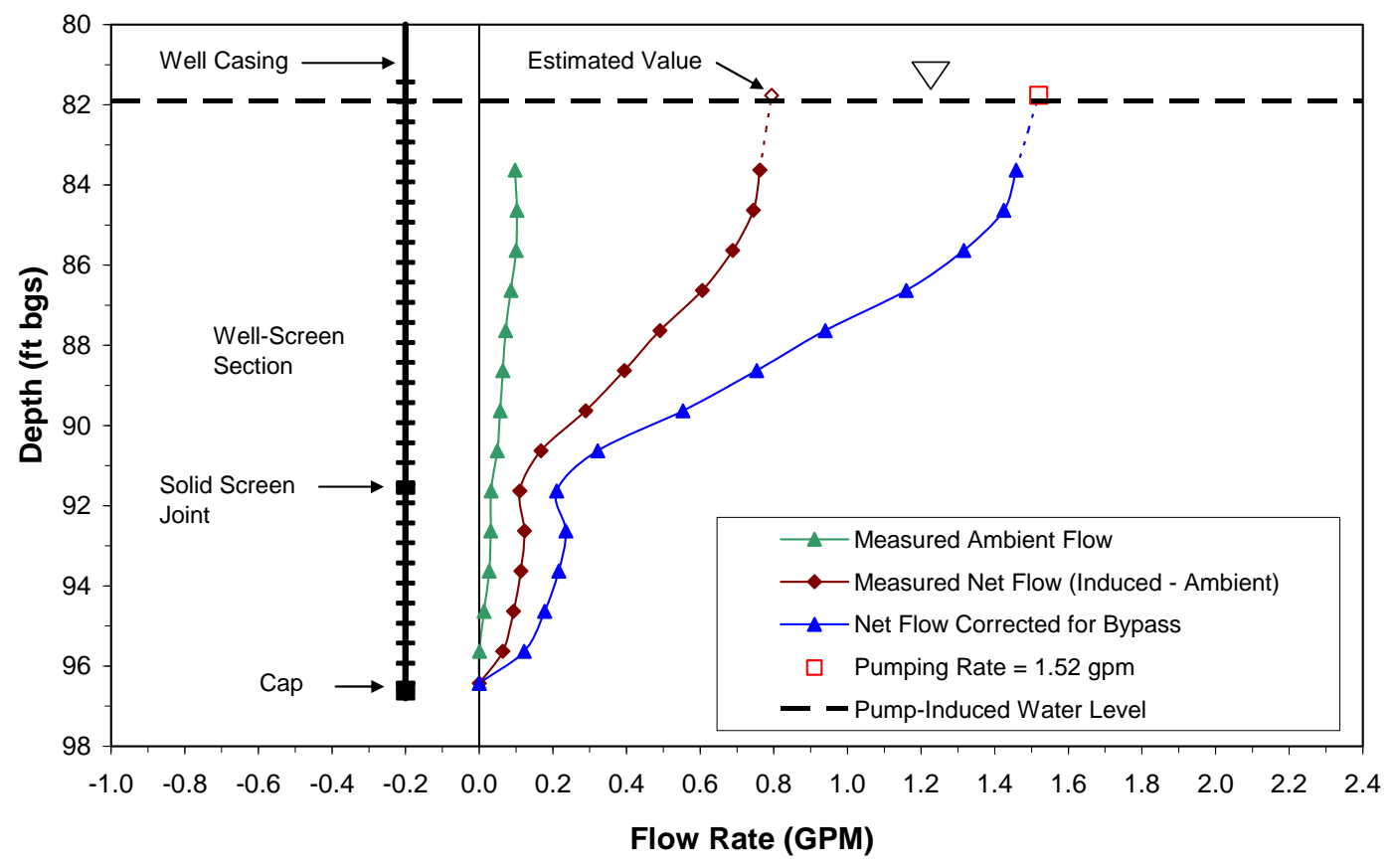

Figure 7.7. Ambient and Dynamic Vertical Flow Profiles, Well 199-D4-36

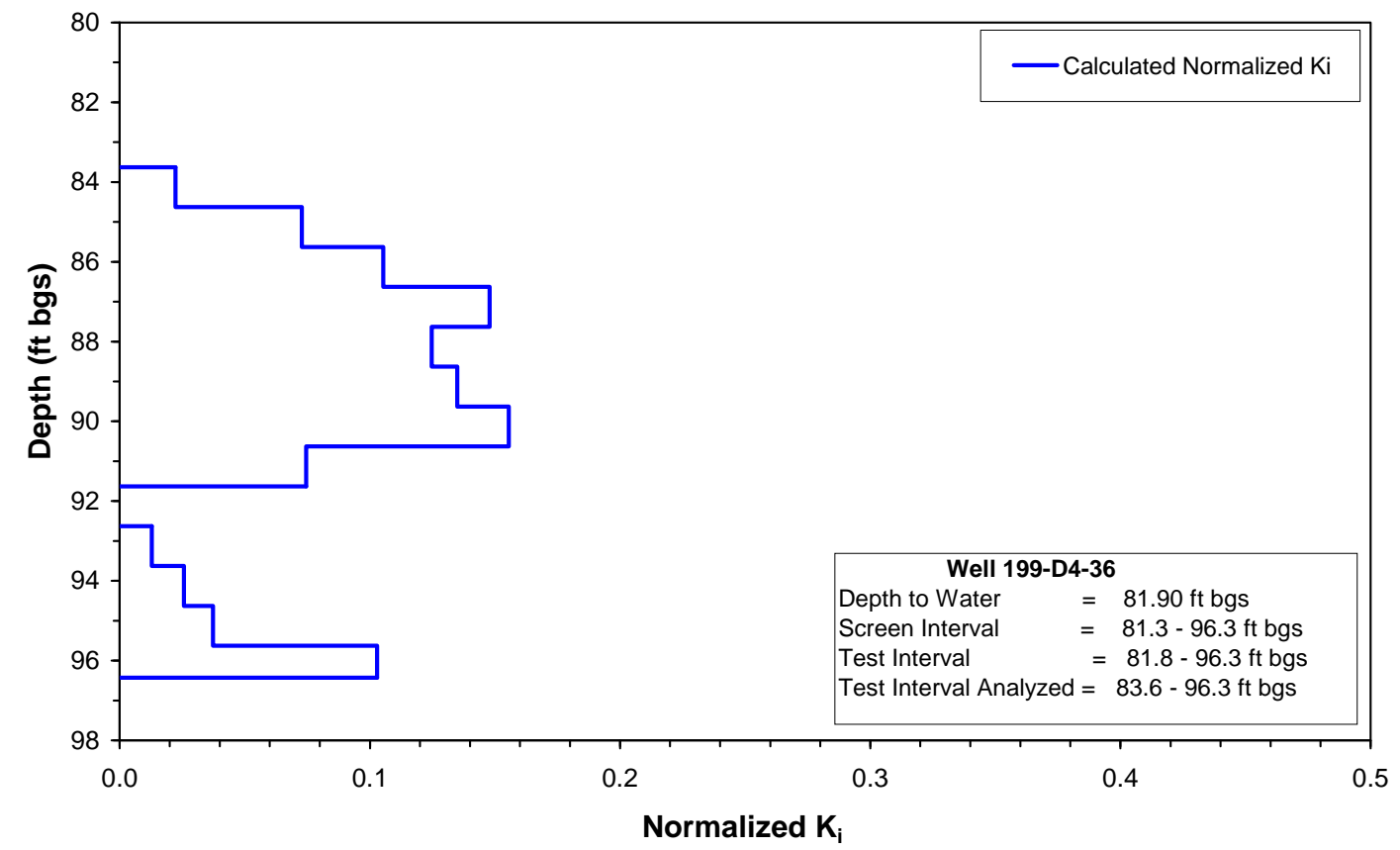

Figure 7.8. Relative Hydraulic Conductivity Profile, Well 199-D4-36 


\subsection{Well 199-D4-37}

Well 199-D4-37 was completed with a 4.6-m (15-ft) long, 15.2-cm (6-in.) inside diameter stainless steel wire-wrap screen at a depth of 25.2 to $29.7 \mathrm{~m}(82.6$ to $97.6 \mathrm{ft}) \mathrm{bgs}$. The screen has a solid joint at a depth of $26.7 \mathrm{~m}(87.6 \mathrm{ft}) \mathrm{bgs}$, and a $0.15-\mathrm{m}(0.5-\mathrm{ft})$ cap was attached below the bottom of the well-screen section. The measured static depth to water before beginning the flowmeter surveys was $25 \mathrm{~m}(81.7 \mathrm{ft})$ bgs, which is above the top of the well-screen section. The well summary log (Figure A.5) indicates that the well-screen test interval consists of sand, sandy gravel, and slightly silty gravelly sand.

An ambient flowmeter survey was performed on May 22, 2007, between 1150 and 1320 PST. A dynamic flowmeter survey was performed on May 23, 2007, between approximately 1200 and 1530 PST after the portable purge tank arrived. Vertical flow was measured in succession from top to bottom, beginning near the top of the well-screen section at a depth of $25.8 \mathrm{~m}(84.7 \mathrm{ft})$ bgs and ending in the cap at the bottom of the well at a depth of $29.9 \mathrm{~m}(98.1 \mathrm{ft}) \mathrm{bgs}$, the point of zero flow. The constant discharge rate during the dynamic survey was $6.25 \mathrm{~L} / \mathrm{min}(1.65 \mathrm{gpm})$.

The ambient and dynamic vertical flow profiles are shown in Figure 7.9. The measured net flow profile in Figure 7.9 shows that the upper $1.2 \mathrm{~m}(4 \mathrm{ft})$ of the well-screen section contributes to the majority of flow. The bottom $3.4 \mathrm{~m}(11 \mathrm{ft})$ of the well-screen section contributes little to the flow profile. This type of profile is reflective of significant vertical bypass flow through the sand pack surrounding the well screen (Boman et al. 1997). This bypass flow suggests the well has a high vertical permeability annulus surrounding the well screen. Flow through such an annulus is isolated from flow through the flowmeter in the lower part of the well-screen section and becomes bypass flow in the upper part of the well-screen section where flow through the flowmeter will be large (Boman et al. 1997). As a result, the error displayed in Figure 7.9 will lead to an erroneously high permeability zone at the top of the wellscreen section. A profile of the relative hydraulic conductivity distribution for this well cannot be determined with these EBF data. 


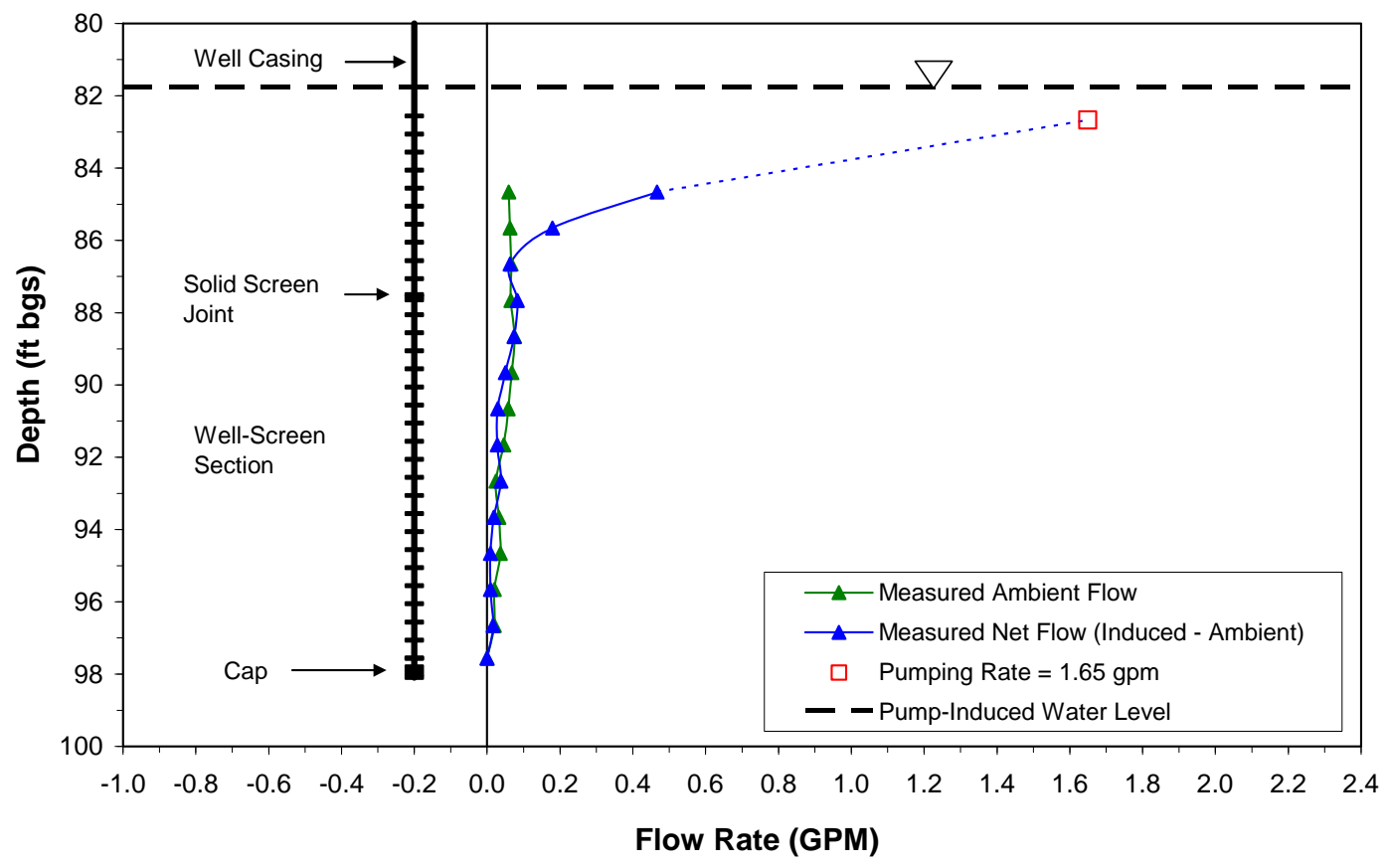

Figure 7.9. Ambient and Dynamic Vertical Flow Profiles, Well 199-D4-37

\subsection{Well 199-D4-40}

Well 199-D4-40 was completed with a 4.7-m (15.3-ft) long, 15.2-cm (6-in.) inside diameter stainless steel wire-wrap screen with a $0.15-\mathrm{m}(0.5-\mathrm{ft})$ cap attached below the bottom of the well-screen section. No solid screen joint was documented in the tubular goods tally. The depth of the well-screen section was 24.9 to $29.6 \mathrm{~m}$ ( 81.7 to $97.0 \mathrm{ft}$ ) bgs. The measured static depth to water before beginning the flowmeter surveys was $24.9 \mathrm{~m}(81.8 \mathrm{ft}) \mathrm{bgs}$, just below the top of the well-screen section. The well summary log (Figure A.6) indicates that the well-screen test interval consists predominantly of sandy gravel, gravelly sand, and sand.

Ambient and dynamic flowmeter surveys were performed on May 23, 2007, between approximately 1600 and 1900 PST. Vertical flow was measured in succession from top to bottom, beginning at a depth of $25.6 \mathrm{~m}(84.0 \mathrm{ft}) \mathrm{bgs}$ near the top of the well-screen section and ending in the cap near the bottom of the well at a depth of $29.7 \mathrm{~m}(97.5 \mathrm{ft}) \mathrm{bgs}$, a point of zero flow. The constant discharge rate during the dynamic survey was $6.28 \mathrm{~L} / \mathrm{min}(1.66 \mathrm{gpm})$.

The ambient and dynamic vertical flow profiles are shown in Figure 7.10. The measured net flow profile in Figure 7.10 shows that the upper $2.5 \mathrm{ft}(0.8 \mathrm{~m})$ of the well-screen section contributes to the majority of flow. Most of the lower part of the well-screen section contributes little to the flow profile. This type of profile is reflective of significant vertical bypass flow through the sand pack surrounding the well screen (Boman et al. 1997). This bypass flow suggests the well has a high vertical permeability annulus surrounding the well screen. Flow through such an annulus is isolated from flow through the flowmeter in the lower part of the well-screen section and becomes bypass flow in the upper part of the well-screen section where flow through the flowmeter will be large (Boman et al. 1997). As a result, the error displayed in Figure 7.10 will lead to an erroneously high permeability zone at the top of the well- 
screen section. A profile of the relative hydraulic conductivity distribution for this well cannot be determined with these EBF data.

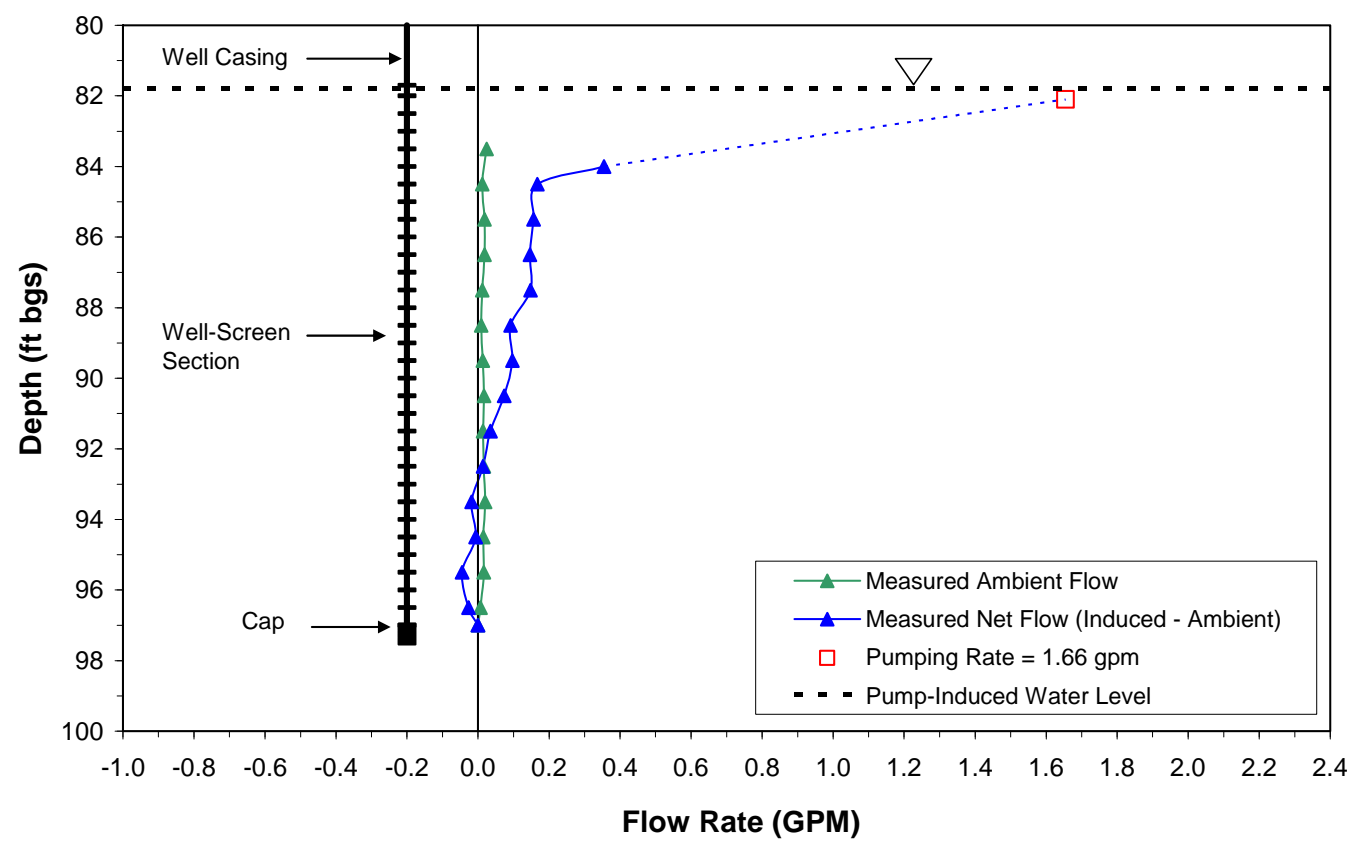

Figure 7.10. Ambient and Dynamic Vertical Flow Profiles, Well 199-D4-40

\subsection{Well 199-D4-90}

Well 199-D4-90 was completed with a 4.6-m (15-ft) long, 10.2-cm (4-in.) inside diameter stainless steel wire-wrap screen, and a $0.6-\mathrm{m}$ (2-ft) sump was attached below the bottom of the well-screen section. No solid screen joint was documented in the tubular goods tally. The depth of the well-screen section was 25.2 to $29.8 \mathrm{~m}$ ( $82.8 \mathrm{ft}$ to $97.8 \mathrm{ft})$ bgs. The measured static depth to water before beginning the flowmeter surveys was $24.8 \mathrm{~m}(81.3 \mathrm{ft}) \mathrm{bgs}$, which is above the top of the well-screen section. The well summary log (Figure A.7) indicates that the well-screen test interval consists of gravelly silty sand and silty sandy gravel.

Ambient and dynamic flowmeter surveys were performed on May 30, 2007, between approximately 0800 and 1130 PST. Vertical flow was measured in succession from top to bottom, beginning at a depth of $25.8 \mathrm{~m}$ ( $84.5 \mathrm{ft})$ bgs near the top of the well-screen section and ending in the sump at a depth of $28.9 \mathrm{~m}$ $(97.8 \mathrm{ft}) \mathrm{bgs}$, a point of zero flow. The constant discharge rate during the dynamic survey was $2.73 \mathrm{~L} / \mathrm{min}$ (0.72 gpm).

The ambient and dynamic vertical profiles are shown in Figure 7.11. The ambient vertical flow profile indicates low, but measurable, upward flow within the lower portion of the saturated well-screen section, with a maximum upward flow of $\sim 0.1 \mathrm{~L} / \mathrm{min}(\sim 0.03 \mathrm{gpm})$. A net flow value was estimated for the top of the well-screen section by applying a slope through measured flow values within the upper part of the screen. An estimated value of $2.76 \mathrm{~L} / \mathrm{min}(0.73 \mathrm{gpm})$ is within $\sim 1 \%$ of the pumping discharge rate. This good agreement indicates that little or no bypass flow occurred during the dynamic test. 
Data from the measured net flow profile were used to calculate normalized hydraulic conductivity. The profile of normalized hydraulic conductivity, presented in Figure 7.12, indicates a generally uniform distribution of normalized $\mathrm{K}_{\mathrm{i}}$ of 0.1 or less over most of the test interval. An exception is a high relative hydraulic conductivity of 0.3 at a depth of 27.4 to $27.7 \mathrm{~m}$ (90 to $91 \mathrm{ft}$ ) bgs.

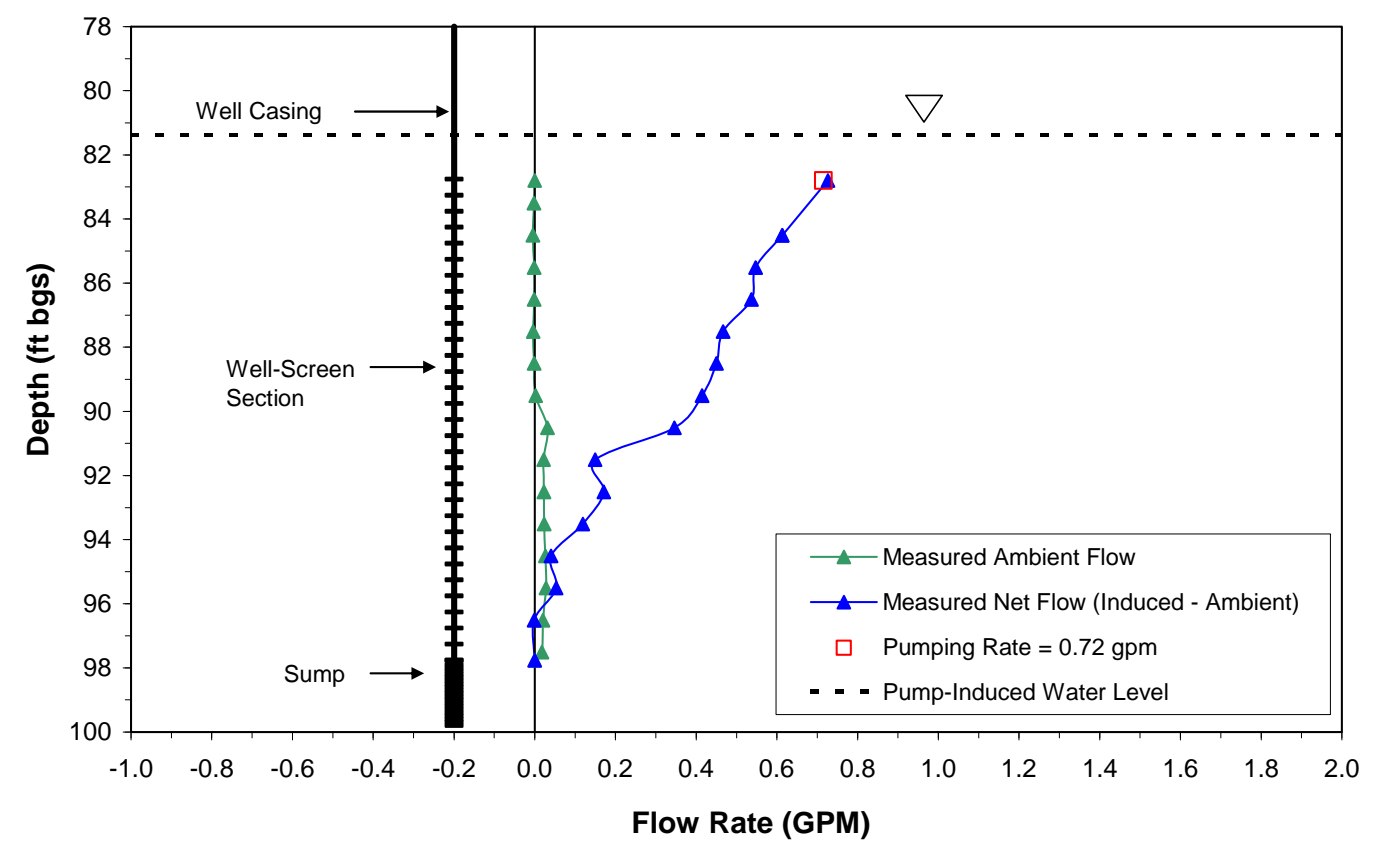

Figure 7.11. Ambient and Dynamic Vertical Flow Profiles, Well 199-D4-90

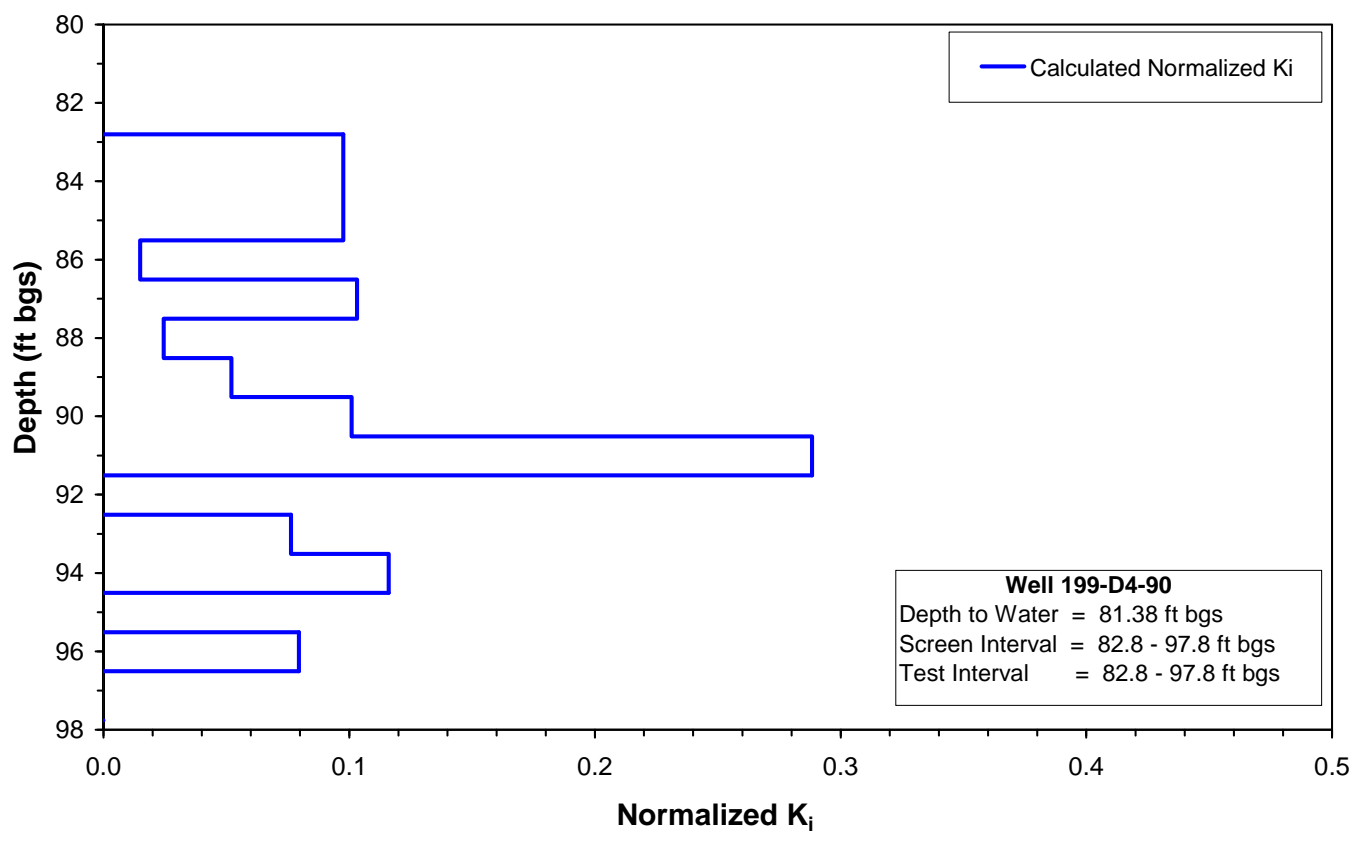

Figure 7.12. Relative Hydraulic Conductivity Profile, Well 199-D4-90 


\subsection{Well 199-D4-91}

Well 199-D4-91 was completed with a 6.1-m (20-ft) long, 10.2-cm (4-in.) inside diameter PVC screen at a depth of 23.5 to $29.6 \mathrm{~m}(77.0$ to $97.0 \mathrm{ft}) \mathrm{bgs}$. The screen has a solid joint at a depth of $26.5 \mathrm{~m}$ $(87.0 \mathrm{ft})$ bgs and a $0.7-\mathrm{m}(2.3-\mathrm{ft})$ sump was attached below the bottom of the well-screen section. The inside diameter of the Schedule 80 PVC casing above the well screen was $9.2 \mathrm{~cm}(35 / 8 \mathrm{in}$.), which presented a problem accessing, and minimizing bypass flow within, the well screen during EBF testing. The measured static depth to water before beginning the flowmeter surveys was $24.7 \mathrm{~m}(81.2 \mathrm{ft}) \mathrm{bgs}$, which is below the top of the well-screen section. The well summary log (Figure A.8) indicates that the well-screen test interval consists of slightly silty sandy gravel, gravelly silty sand, and gravelly sand.

Ambient and dynamic flowmeter surveys were performed on May 30, 2007, between 1250 and 1545 PST. Vertical flow was measured in succession from top to bottom, beginning at a depth of $25.8 \mathrm{~m}$ $(84.7 \mathrm{ft})$ bgs near the top of the water column and ending in the sump at the bottom of the well at a depth of $30.1 \mathrm{~m}(98.7 \mathrm{ft}) \mathrm{bgs}$, a point of zero flow. The constant discharge rate during the dynamic survey was $2.80 \mathrm{~L} / \mathrm{min}(0.74 \mathrm{gpm})$.

The ambient and dynamic vertical flow profiles are shown in Figure 7.13. The ambient vertical flow profile indicates a range of $-0.42 \mathrm{~L} / \mathrm{min}(-0.11 \mathrm{gpm})$ downward flow in the upper part of the well-screen test interval to $0.26 \mathrm{~L} / \mathrm{min}(0.07 \mathrm{gpm})$ upward flow in the lower part of the well screen. The large difference between measured net flow (i.e., induced minus ambient flow) and the constant discharge rate suggests that bypass flow occurred during the dynamic test. A correction for bypass flow was applied by multiplying the net flow by a correction factor of 2.23. This correction factor represents the ratio between the constant discharge rate and a flow value estimated for the top of the test interval by applying a slope through measured values within the upper part of the test interval. A comparison of the measured net flow and the net flow corrected for total bypass indicates that $\sim 55 \%$ of the flow bypassed the flowmeter.

The net flow corrected for total bypass flow was used to calculate normalized hydraulic conductivity. The profile of normalized hydraulic conductivity, presented in Figure 7.14, shows slightly higher $\mathrm{K}_{\mathrm{i}}$ values at depths of $\sim 27$ to $28 \mathrm{~m}$ ( $\sim 88$ to $91 \mathrm{ft})$ bgs and $\sim 30 \mathrm{~m} \mathrm{(} \sim 97 \mathrm{ft})$ bgs than in the remaining part of the test interval. 


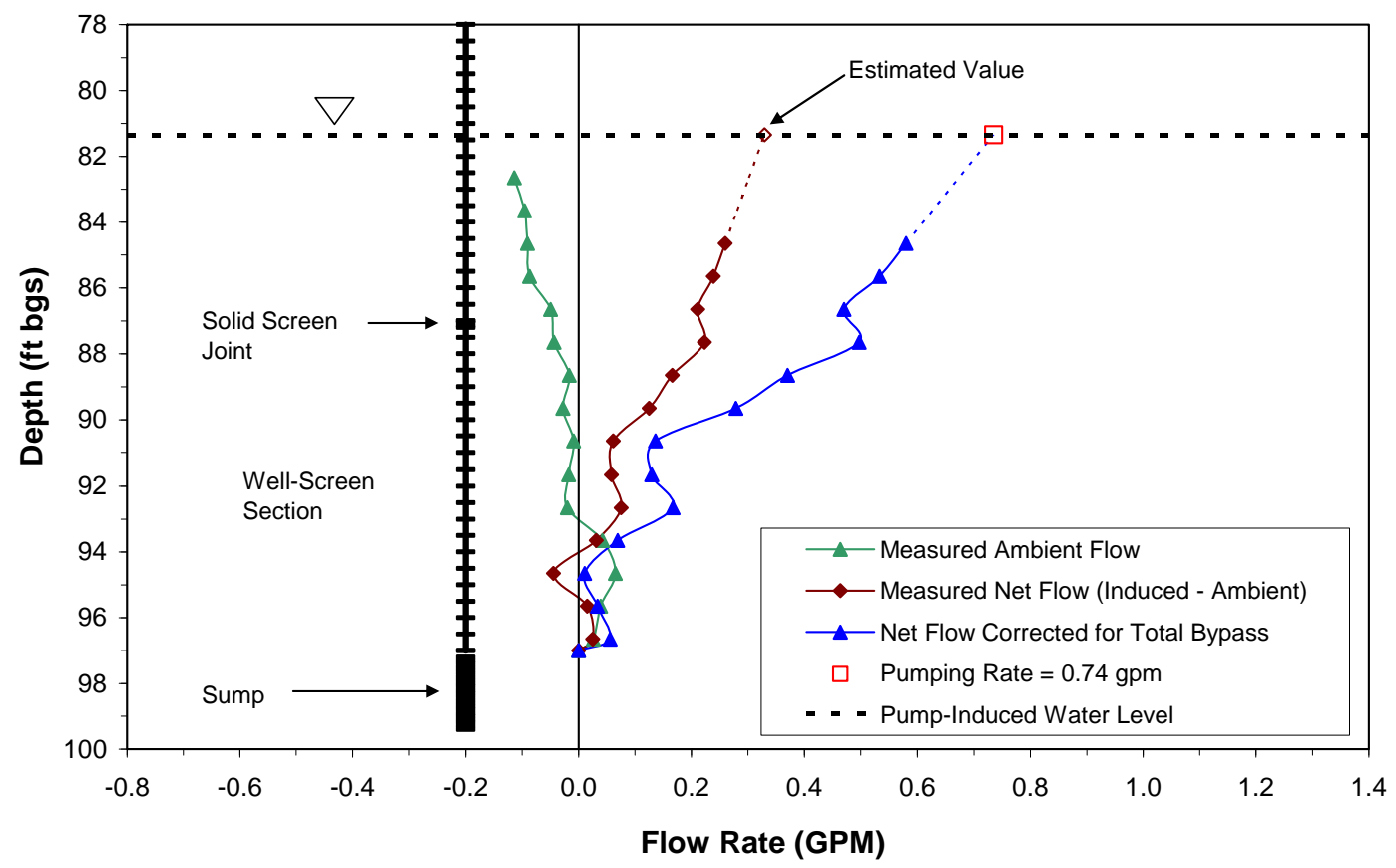

Figure 7.13. Ambient and Dynamic Vertical Flow Profiles, Well 199-D4-91

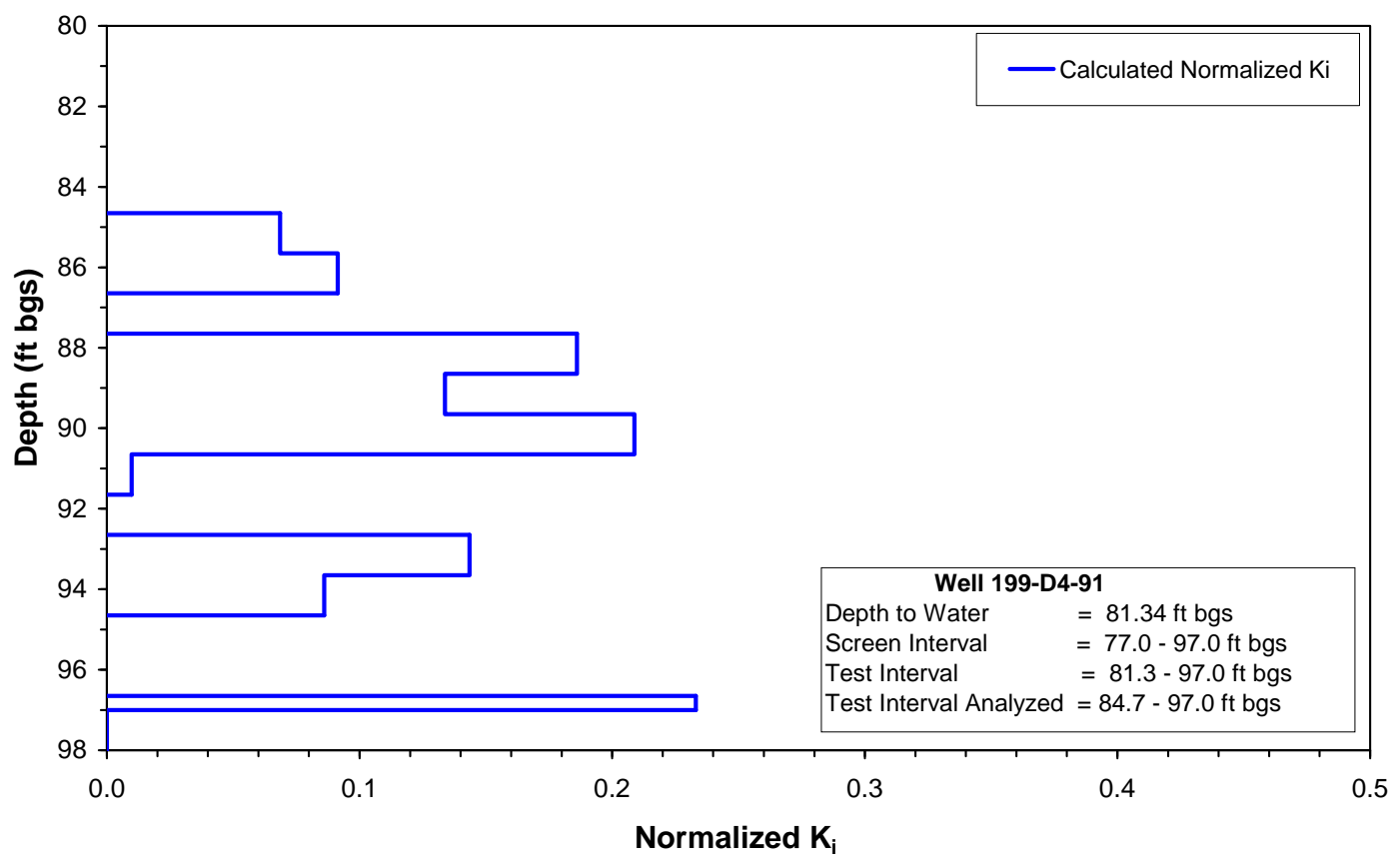

Figure 7.14. Relative Hydraulic Conductivity Profile, Well 199-D4-91 


\subsection{Well 199-D4-92}

Well 199-D4-92 was completed with a 6.1-m (20-ft) long, 10.2-cm (4-in.) inside diameter PVC screen at a depth of 25.3 to $31.4 \mathrm{~m}(83.0$ to $103.0 \mathrm{ft}) \mathrm{bgs}$. The screen has a solid joint at a depth of $28.3 \mathrm{~m}$ $(93.0 \mathrm{ft}) \mathrm{bgs}$, and a $0.8-\mathrm{m}(2.5-\mathrm{ft})$ sump was attached below the bottom of the well-screen section. The measured depth to bottom of the well was $31.5 \mathrm{~m}(103.3 \mathrm{ft}) \mathrm{bgs}$, which indicates that the bottom $0.7 \mathrm{~m}$ $(2.2 \mathrm{ft})$ of the sump was filled in with sediment. The inside diameter of the Schedule $80 \mathrm{PVC}$ casing above the well screen was $9.2 \mathrm{~cm}$ ( $35 / 8 \mathrm{in}$.), which presented a problem accessing, and minimizing bypass flow within, the well screen during EBF testing. A 9.2-cm (3 5/8-in.) diameter rubber gasket was used for the seal. The measured static depth to water before beginning the flowmeter surveys was $24.8 \mathrm{~m}$ $(81.3 \mathrm{ft}) \mathrm{bgs}$, which is above the top of the well-screen section. The well summary log (Figure A.9) indicates that the well-screen test interval consists of silty sandy gravel and sandy gravel.

Ambient and dynamic flowmeter surveys were performed on May 30, 2007, between approximately 0840 and 1200 PST. Vertical flow was measured in succession from top to bottom, beginning at a depth of $25.7 \mathrm{~m}(84.4 \mathrm{ft})$ bgs near the top of the well-screen section and ending near the bottom of the wellscreen section at a depth of $31 \mathrm{~m}(101.4 \mathrm{ft}) \mathrm{bgs}$, a point of zero flow. The flowmeter could not be lowered below this depth. The constant discharge rate during the dynamic survey was $2.73 \mathrm{~L} / \mathrm{min}(0.72 \mathrm{gpm})$.

The ambient and dynamic vertical flow profiles are shown in Figure 7.15. The measured net flow profile in Figure 7.15 shows that the upper $\sim 0.6 \mathrm{~m} \mathrm{(} \sim 2 \mathrm{ft})$ of the well-screen section contributes to the majority of flow. The bottom $\sim 5.5 \mathrm{~m}(\sim 18 \mathrm{ft})$ of the well-screen section contributes little to the flow profile. This type of profile is reflective of significant vertical bypass flow through the sand pack surrounding the well screen (Boman et al. 1997). This bypass flow suggests the well has a high vertical permeability annulus surrounding the well screen. Bypass flow through such an annulus is isolated from flow through the flowmeter in the lower part of the well-screen section and becomes bypass flow in the upper part of the well-screen section where flow through the flowmeter will be large (Boman et al. 1997). As a result, the error displayed in Figure 7.15 will lead to an erroneously high permeability zone at the top of the well-screen section. A profile of the relative hydraulic conductivity distribution for this well cannot be determined with these EBF data. 


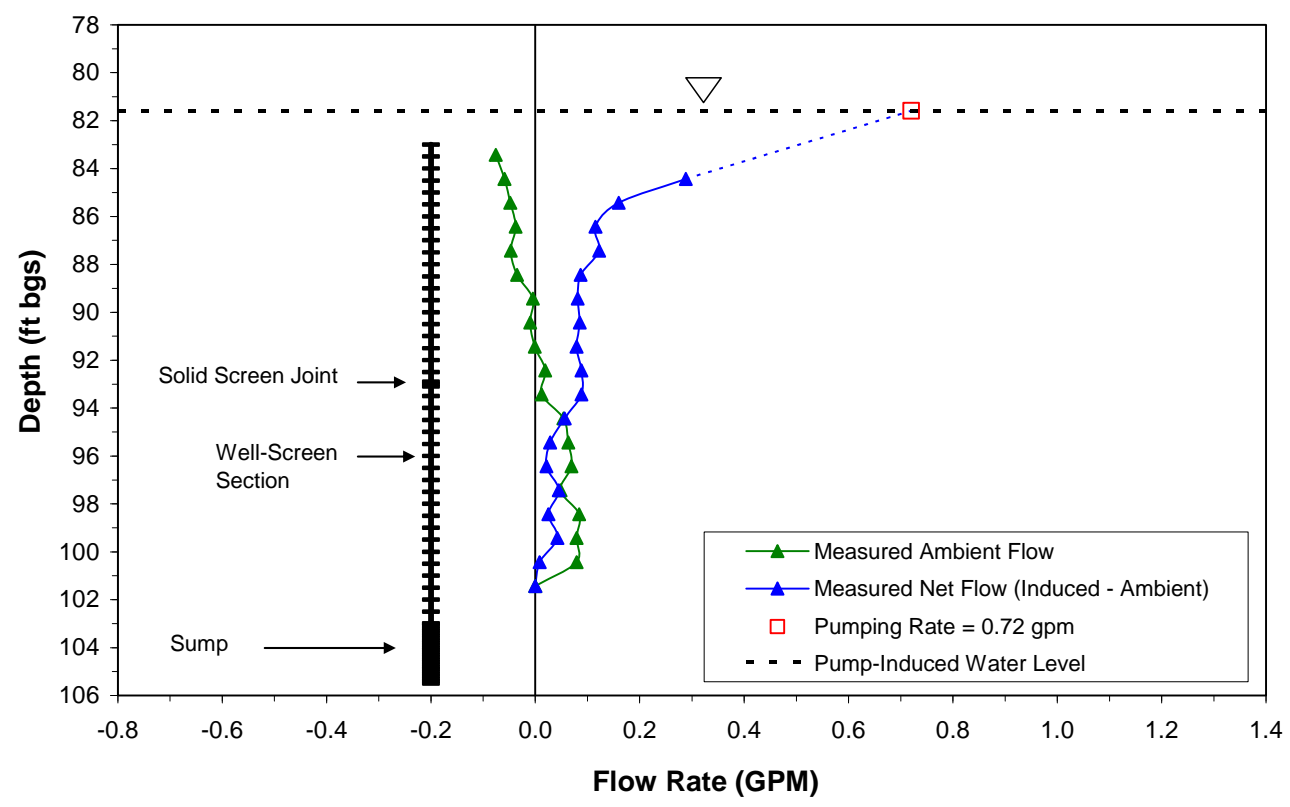

Figure 7.15. Ambient and Dynamic Vertical Flow Profiles, Well 199-D4-92

\subsection{Well 199-D4-93}

Well 199-D4-93 was completed with a 6.1-m (20-ft) long, 10.2-cm (4-in.) inside diameter stainless steel wire-wrap screen at a depth of 25.1 to $31.2 \mathrm{~m}(82.2$ to $102.2 \mathrm{ft})$ bgs. A $0.6-\mathrm{m}(2-\mathrm{ft})$ sump was placed at the bottom of the well-screen section. No solid screen joint was documented in the tubular goods tally. The measured static depth to water before beginning the flowmeter surveys was $24.6 \mathrm{~m}(80.6 \mathrm{ft}) \mathrm{bgs}$, which lies above the top of the well-screen section. The well summary log (Figure A.10) indicates that the well-screen test interval consists of silty sandy gravel, sand, and sandy gravel.

Ambient and dynamic flowmeter surveys were performed on May 29, 2007, between approximately 1300 and 1700 PST. Vertical flow was measured in succession from top to bottom, beginning at a depth of $25.8 \mathrm{~m}(84.5 \mathrm{ft}) \mathrm{bgs}$ near the top of the well screen and ending in the sump at a depth of $30.9 \mathrm{~m}$ $(101.5 \mathrm{ft}) \mathrm{bgs}$, a point of zero flow. The constant discharge rate during the dynamic survey was $6.09 \mathrm{~L} / \mathrm{min}(1.61 \mathrm{gpm})$.

The ambient and dynamic vertical flow profiles are shown in Figure 7.16. The ambient vertical flow profile indicates measurable upward flow of $0.4 \mathrm{~L} / \mathrm{min}(0.1 \mathrm{gpm})$ within the lower half of the well-screen test interval and measurable downward flow of $-0.3 \mathrm{~L} / \mathrm{min}(-0.08 \mathrm{gpm})$ within the upper part of the wellscreen test interval. The large difference between measured net flow (i.e., induced minus ambient flow) near the top of the well-screen section and the pumping discharge rate suggests that bypass flow occurred during the dynamic test. The net flow was corrected for bypass flow by multiplying the net flow by a correction factor of 2.21. This correction factor represents the ratio between the pumping discharge rate and a flow value estimated for the top of the test interval by applying a slope through measured values within the upper part of the well-screen section. A comparison of the measured net flow and the net flow corrected for bypass indicates that $\sim 54 \%$ of the flow bypassed the flowmeter. 
The net flow profile corrected for bypass flow was used to calculate normalized hydraulic conductivity. The profile of normalized hydraulic conductivity, presented in Figure 7.17, indicates a generally uniform distribution of hydraulic conductivity over the well-screen test interval. An exception is a thin, high relative $\mathrm{K}_{\mathrm{i}}$ zone at a depth of $\sim 29.9 \mathrm{~m}(\sim 98 \mathrm{ft})$ bgs.

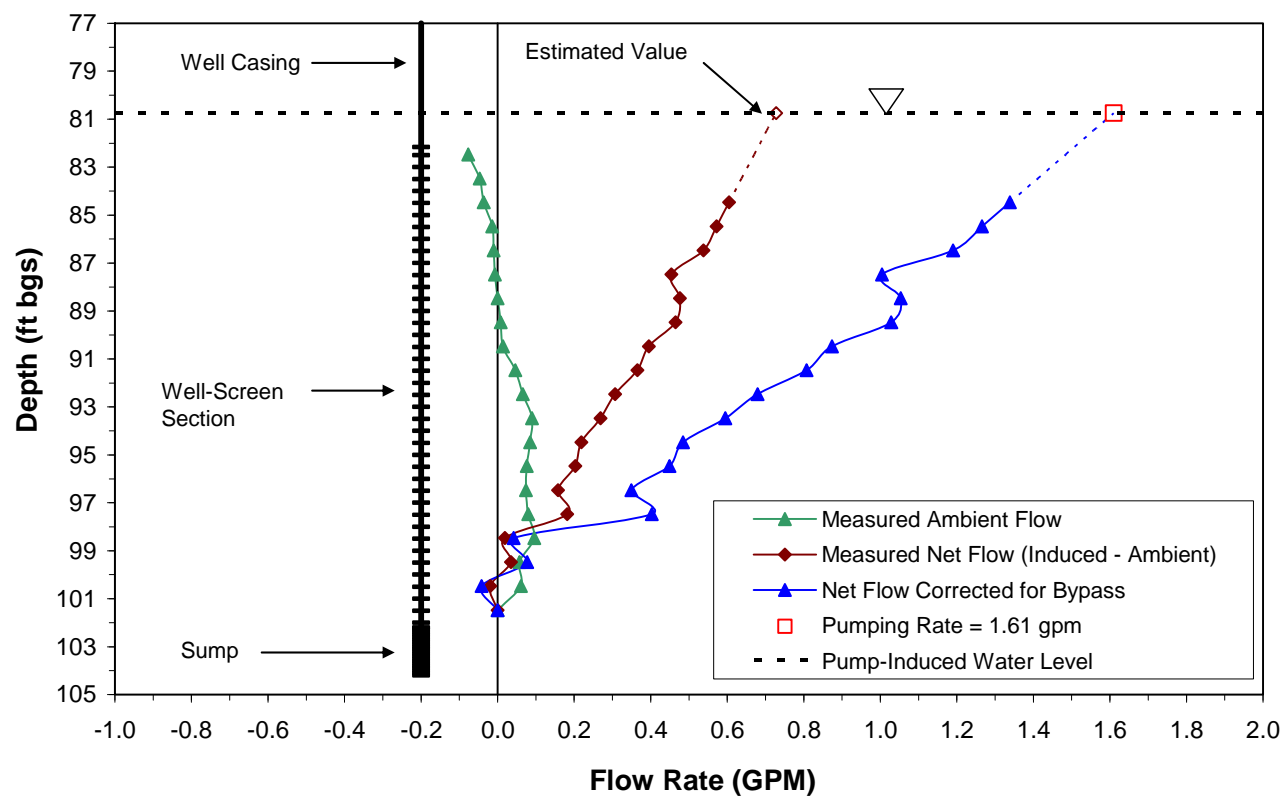

Figure 7.16. Ambient and Dynamic Vertical Flow Profiles, Well 199-D4-93

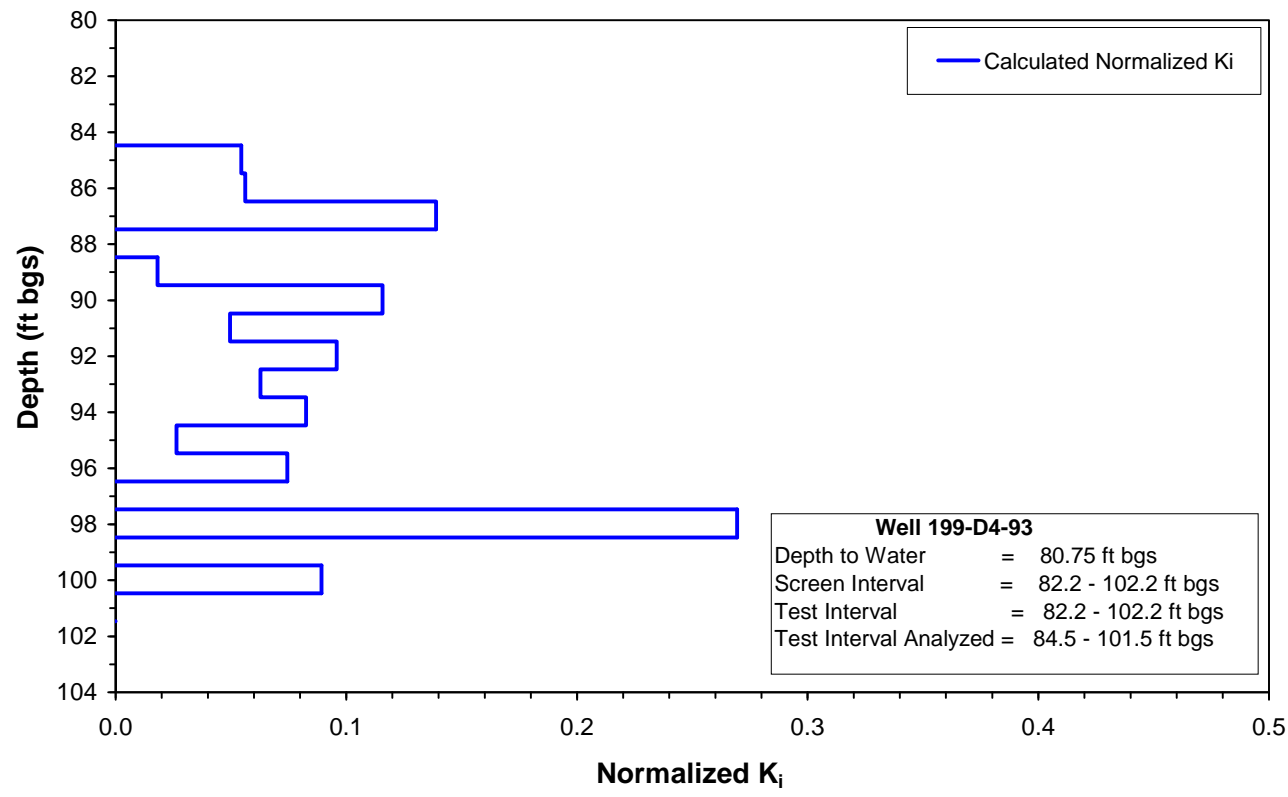

Figure 7.17. Normalized Hydraulic Conductivity Profile, Well 199-D4-93 


\subsection{Conclusions}

Survey data collected by the electromagnetic borehole flowmeter indicated low, but measurable, upward ambient flow in four of the selected ISRM barrier wells tested with the EBF at the 100-D Area zero-valent iron site, with upward flow values ranging up to a maximum observed rate of $0.14 \mathrm{gpm}$. Downward ambient flow ranged up to a maximum observed rate of $-0.42 \mathrm{~L} / \mathrm{min}(-0.11 \mathrm{gpm})$ in the upperpart of the well-screen test intervals for three of the wells tested. Probable causes of ambient vertical flow conditions include aquifer vertical heterogeneity and river-stage boundary fluctuations. Net dynamic flow was successfully characterized in 7 of the 10 wells tested with the EBF. However, vertical bypass flow past the EBF probe and through a high-permeable sand pack surrounding the well screen accounted for $44 \%$ to $55 \%$ of the measured flow under pumping conditions. For three of the wells surveyed with the $\mathrm{EBF}$, the net flow distribution could not be characterized because $>80 \%$ of flow under pumping conditions bypassed the EBF probe.

For the southwest group of wells tested with the EBF (199-D4-25, 199-D4-26, 199-D4-27, 199D4-92, and 199-D4-93), the inferred normalized hydraulic conductivity profiles indicate a generally uniform distribution of permeability above a higher-permeable zone within the lower part of the wellscreen test intervals at depth of $\sim 29$ to $30.5 \mathrm{~m}$ ( $\sim 96$ to $100 \mathrm{ft}) \mathrm{bgs}$, with normalized relative $\mathrm{K}_{\mathrm{i}}$ values ranging up to 0.27. For the northeast group of wells tested (199-D4-36, 199-D4-37, 199-D4-40, 199-D4-90, and 199-D4-91), the normalized hydraulic conductivity profiles exhibited a high permeable

zone generally within the middle portion of the well-screen test intervals at a depth of $\sim 26$ to $27.7 \mathrm{~m}$ ( $\sim 86$ to $91 \mathrm{ft}$ ) bgs, with normalized $\mathrm{K}_{\mathrm{i}}$ values ranging up to 0.3 . 


\subsection{References}

Arnold KB, and FJ Molz. 2000. "In-Well Hydraulics of the Electromagnetic Borehole Flowmeter: Further Studies." Ground Water Monitoring \& Remediation 20(1):52-55.

Boman GK, FJ Molz, and KD Boone. 1997. "Borehole Flowmeter Application in Fluvial Sediments: Methodology, Results, and Assessment." Ground Water 35(3):443-450.

Dinwiddie CL, NA Foley, and FJ Molz. 1999. "In-Well Hydraulics of the Electromagnetic Borehole Flowmeter." Ground Water 37(2):305-315.

Javandel I, and PA Witherspoon. 1969. "A Method of Analyzing Transient Fluid Flow in Multilayered Aquifers." Water Resources Research (5):856-869.

Molz FJ, and SC Young. 1993. "Development and Application of Borehole Flowmeters for Environmental Assessment." The Log Analyst 3:13-23.

Molz FJ, GK Boman, SC Young, and WR Waldrop. 1994. "Borehole Flowmeters: Applications and Data Analysis.” Journal of Hydrology (163):347-371.

U.S. Department of Energy (DOE). 2004. Evaluation of Amendments for Mending the ISRM Barrier. Technical Assistance Project \#33. Richland, Washington. Available at:

http://costperformance.org/remediation/pdf/project33 evaluating_amend.pdf. Accessed 02-03-2009.

Waldrop WR, and JK Waldrop. 2004. Electromagnetic Borehole Flowmeter Test of the Wells of 100-D Area In Situ Redox Manipulation (ISRM) Barrier Site, Hanford Site, Washington State. QEC-T-155, Quantum Engineering Corporation, Loudon, Tennessee.

Williams MD, VR Vermeul, JE Szecsody, and JS Fruchter. 2000. 100-D Area In Situ Redox Treatability Test for Chromate-Contaminated Groundwater. PNNL-13349, Pacific Northwest National Laboratory, Richland, Washington.

WMP-26460. 2005. Four Characterization and Monitoring Wells Drilled in the 100-D/DR ISRM Treatment Zone in Fiscal Year 2005: Summary of Drilling Activities. Rev. 0, Fluor Hanford, Inc., Richland, Washington.

Young SC, HE Julian, HS Pearson, FJ Molz, and GK Boman. 1998. Application of the Electromagnetic Borehole Flowmeter. U.S. Environmental Protection Agency Research Report EPA/600/R-98/058, Ada, Oklahoma. 
Appendix A

Well As-Built Diagrams 


\section{Appendix A}

\section{Well As-Built Diagrams}

0515636

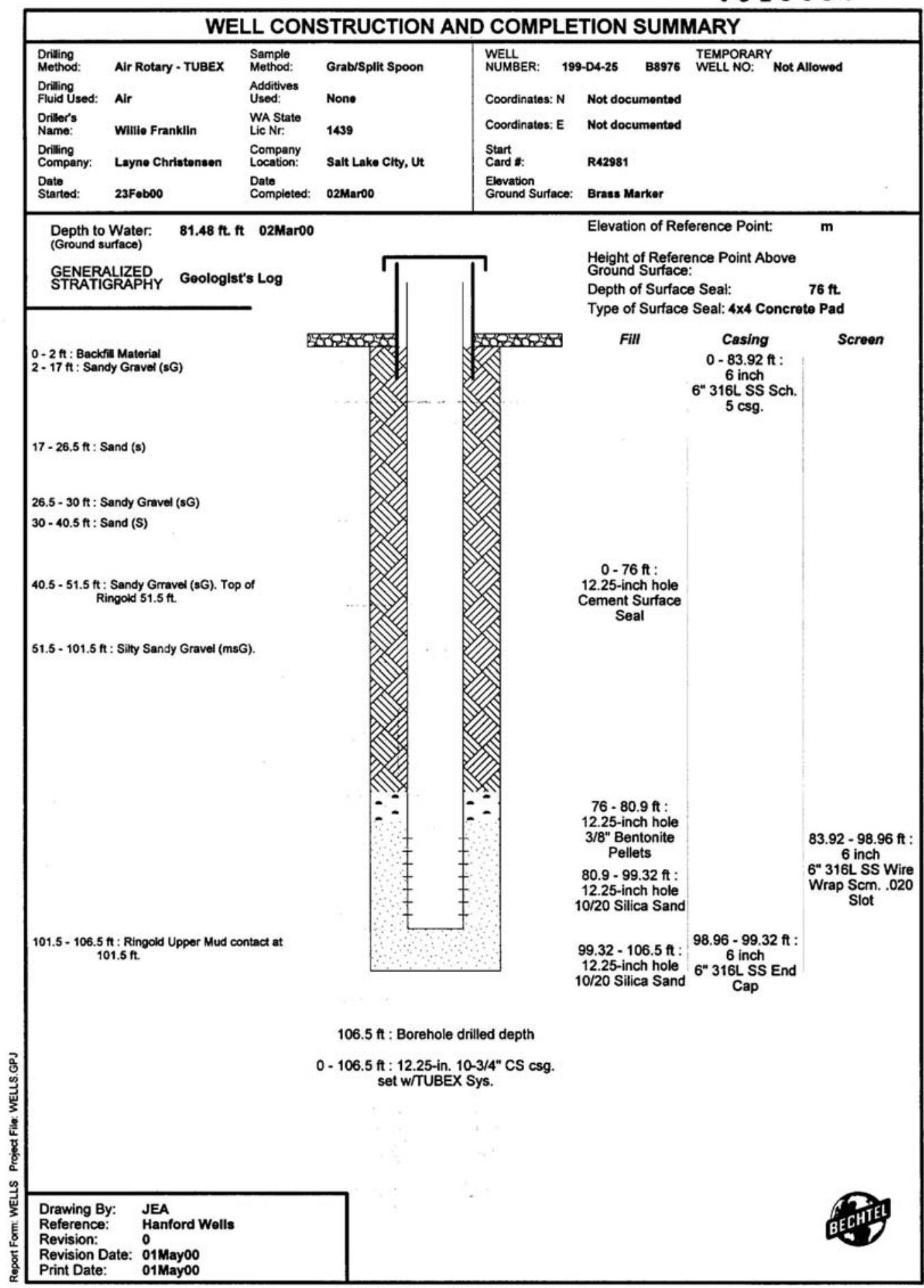

Figure A.1. Well 199-D4-25 
0515637

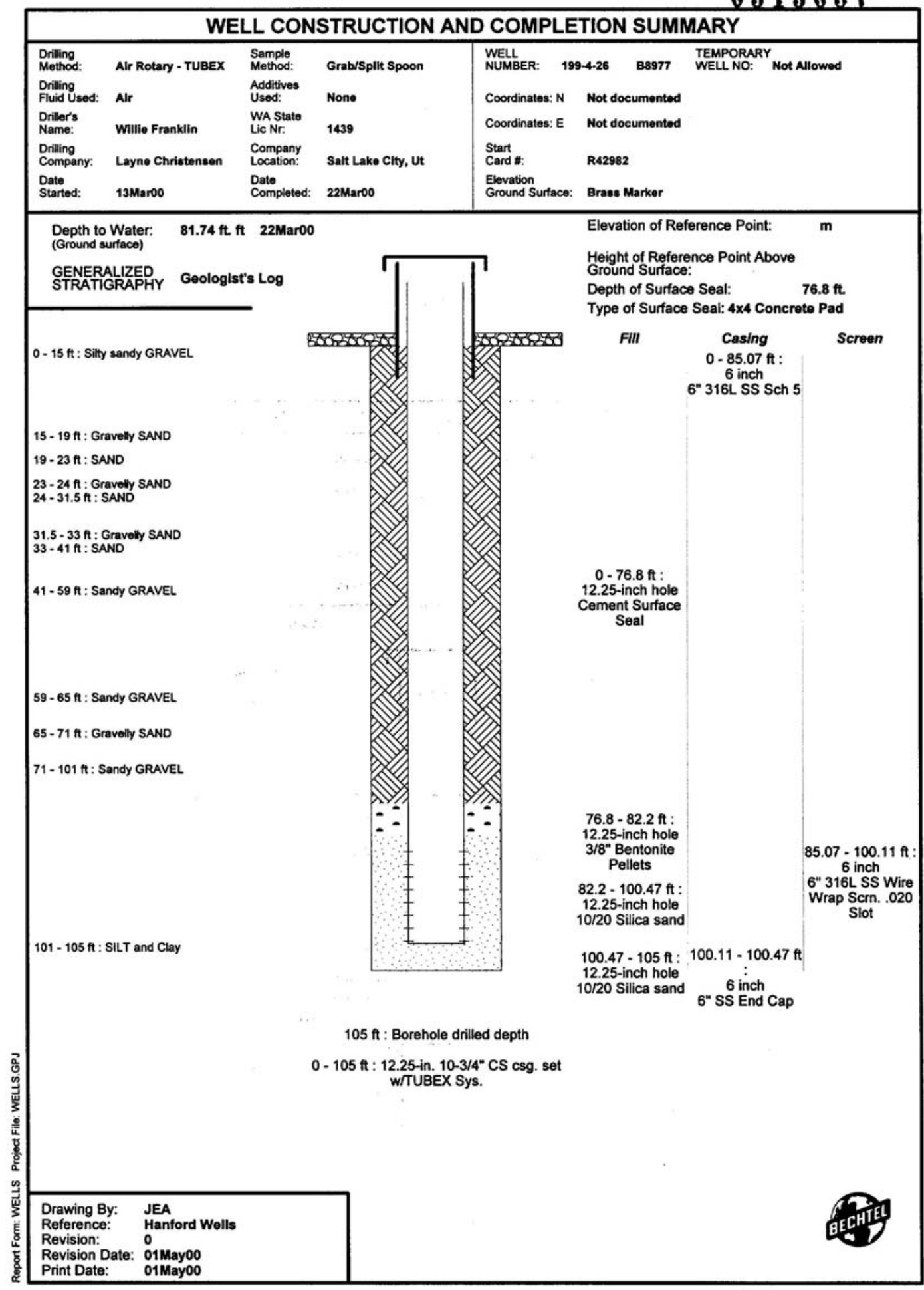

Figure A.2. Well 199-D4-26 
0515638

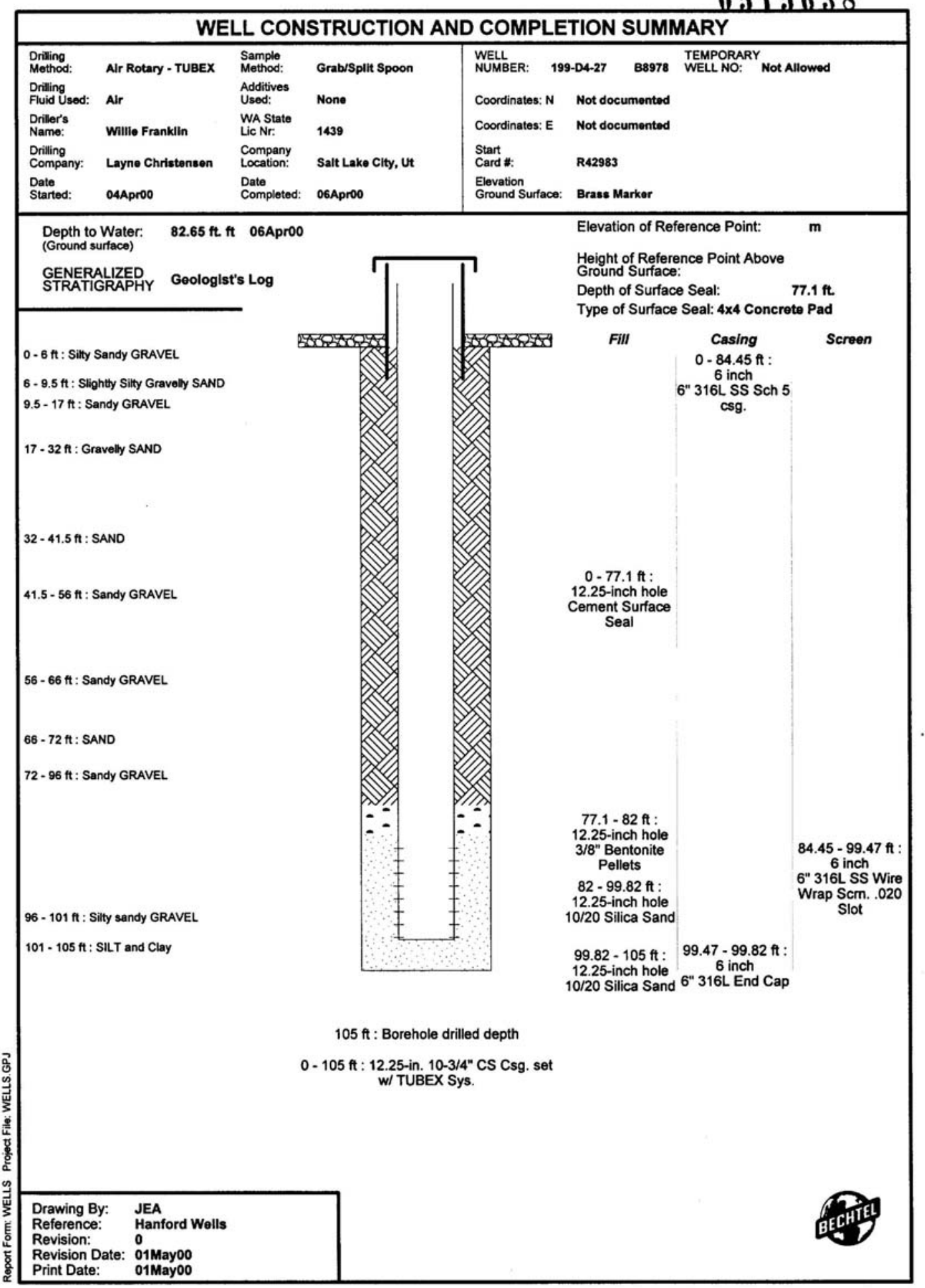

Figure A.3. Well 199-D4-27 


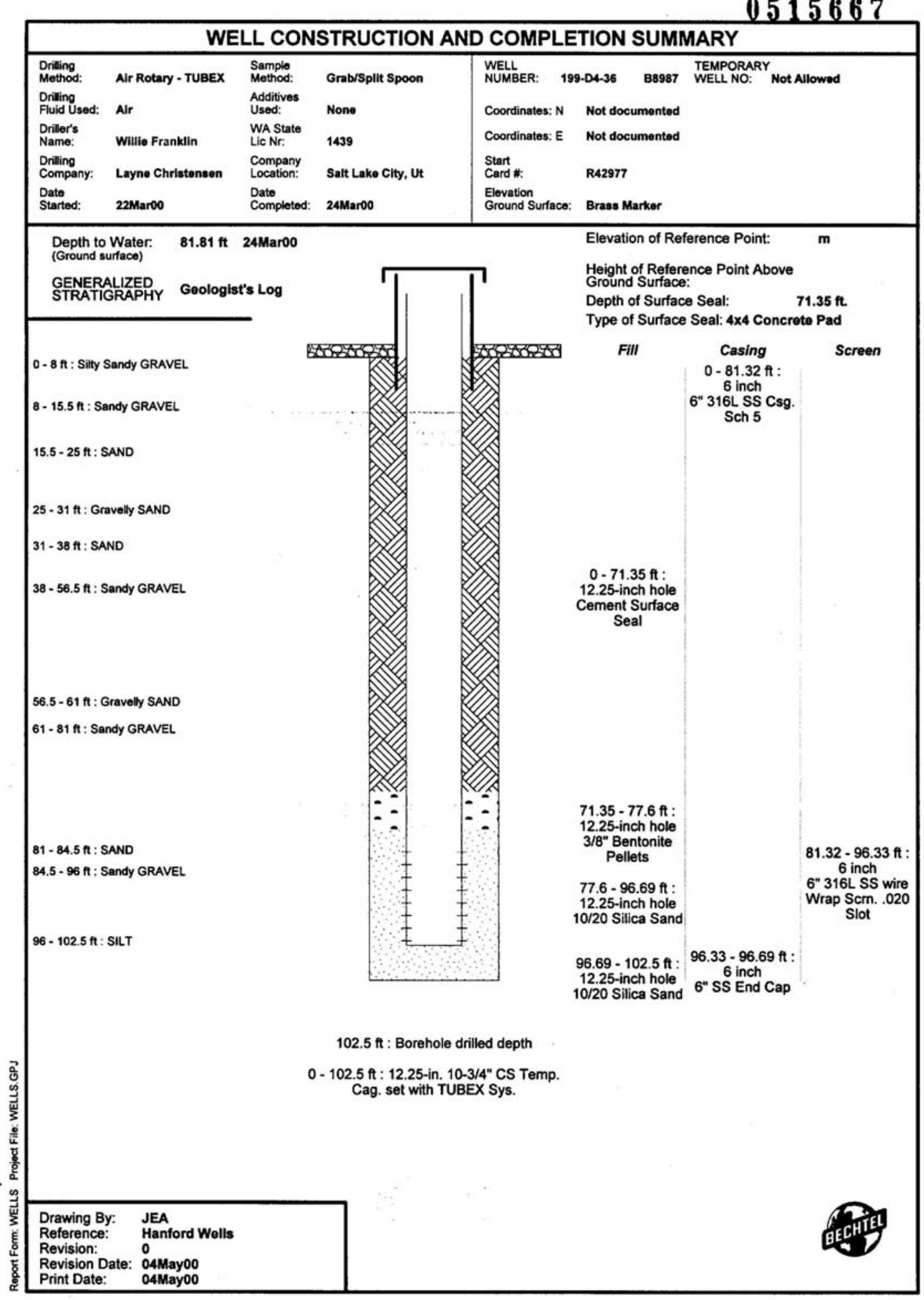

Figure A.4. Well 199-D4-36 
0515666

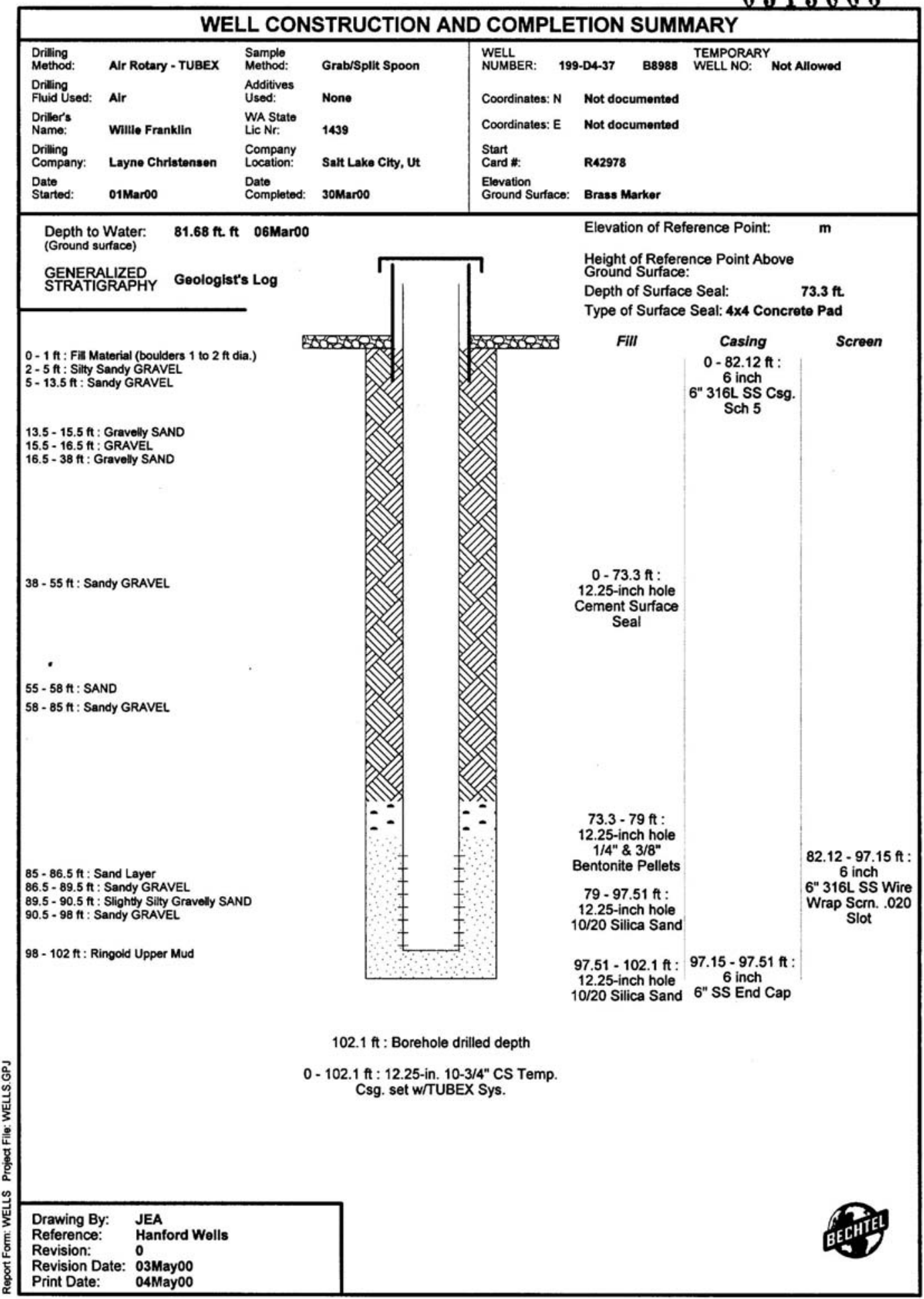

Figure A.5. Well 199-D4-37 
0532889

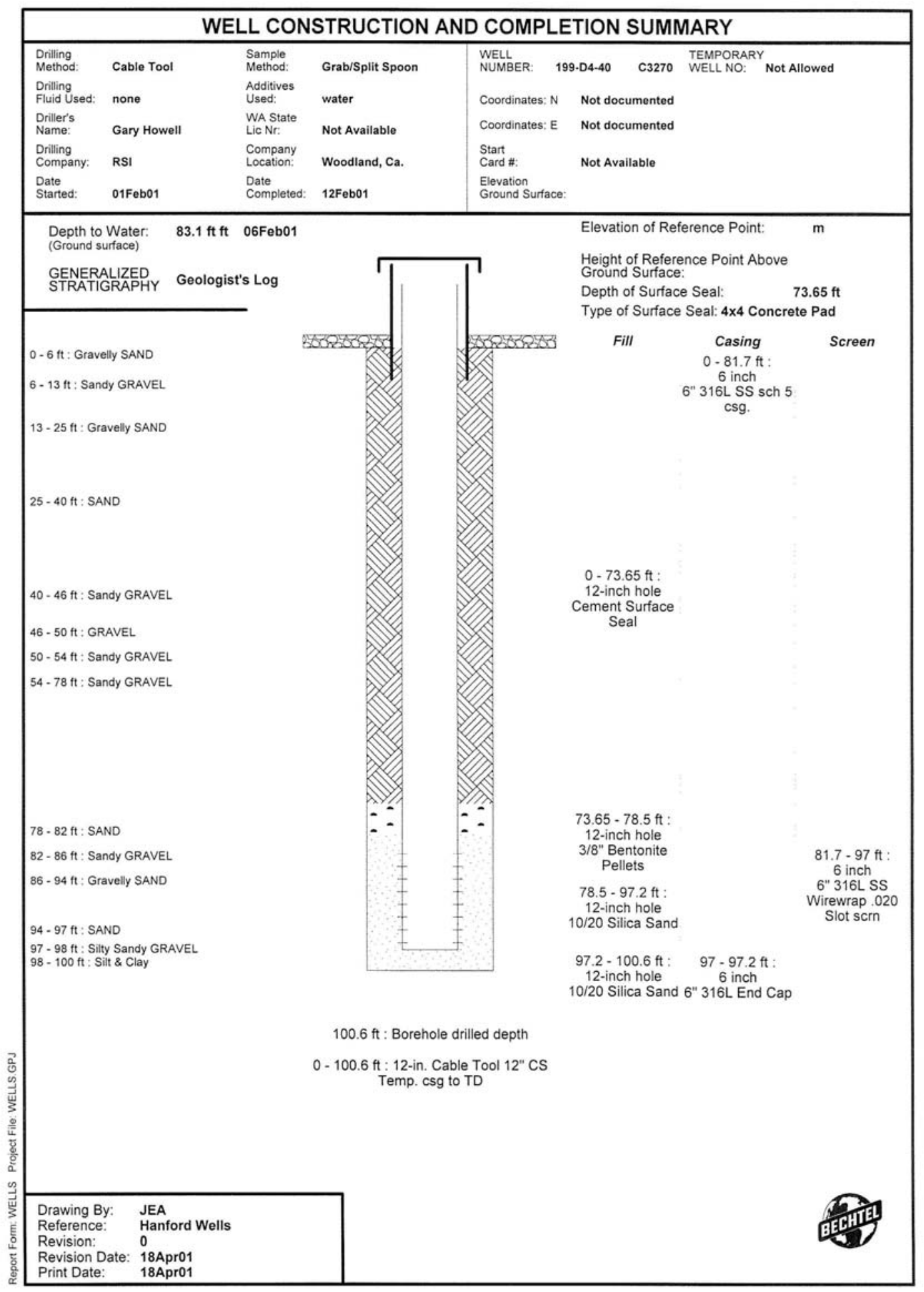

Figure A.6. Well 199-D4-40 
WMP-26460, REV. 0

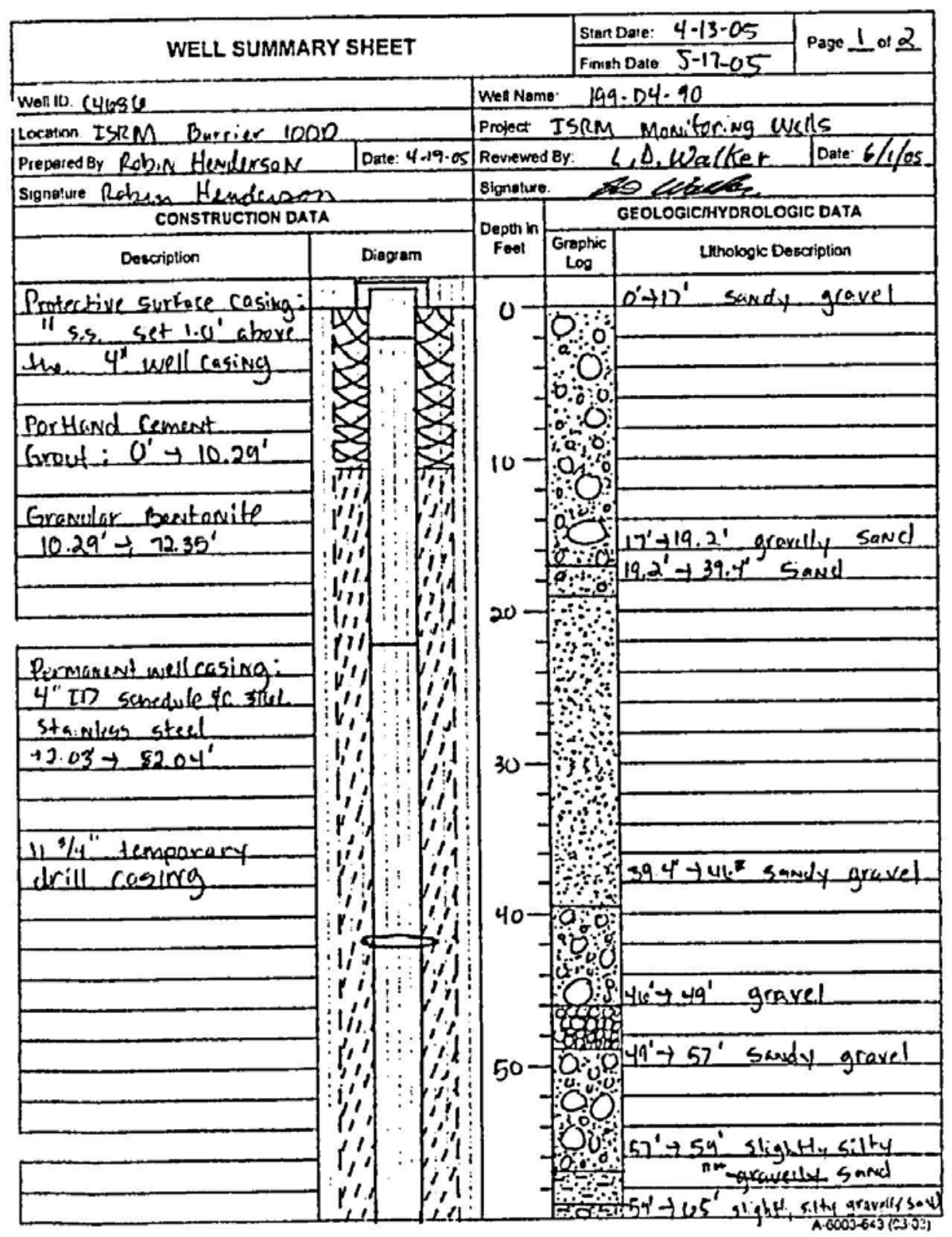

Figure A.7. Well 199-D4-90 
WMP-26460, REV. 0

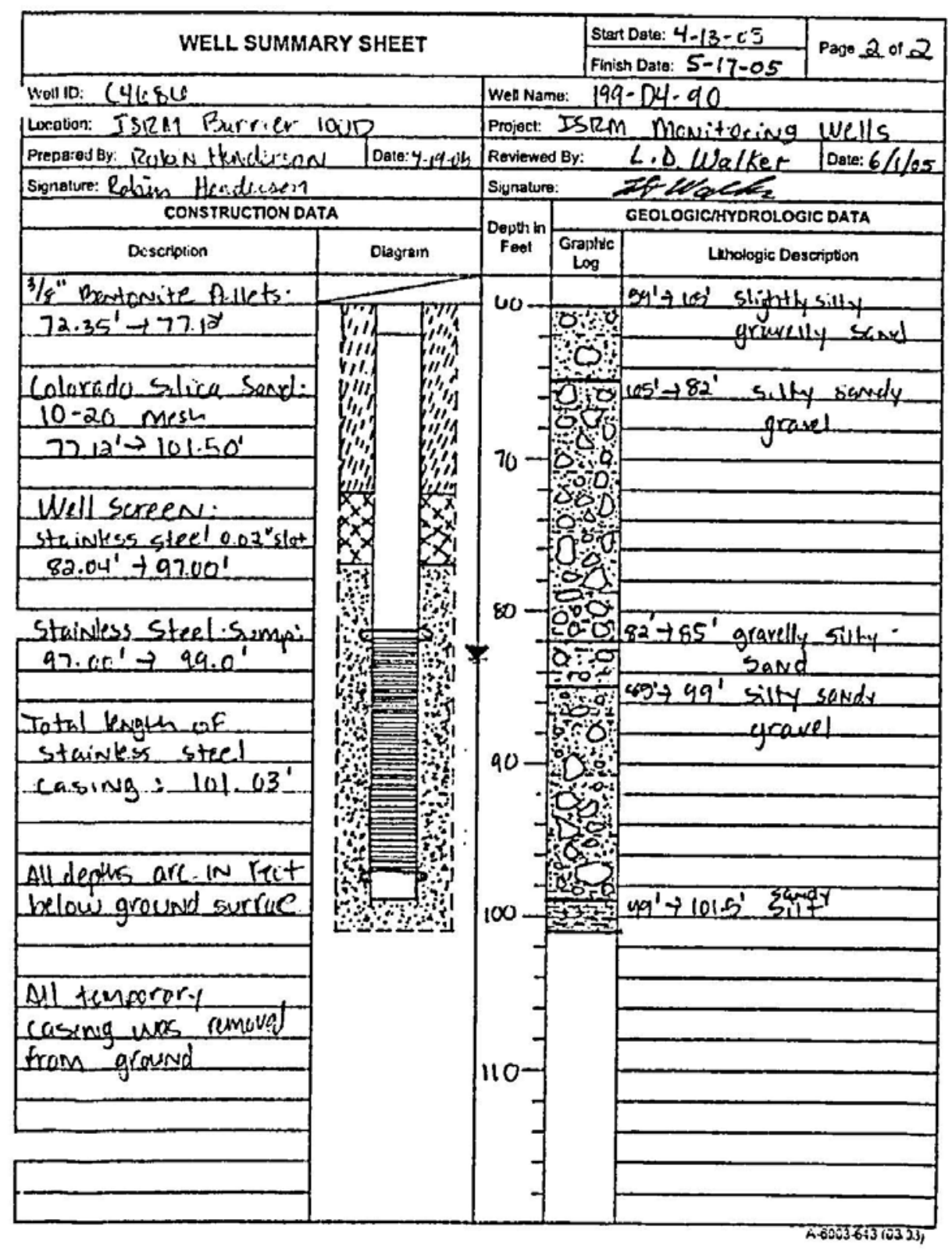

Figure A.7 (contd) 
WMP-26460, REV. 0

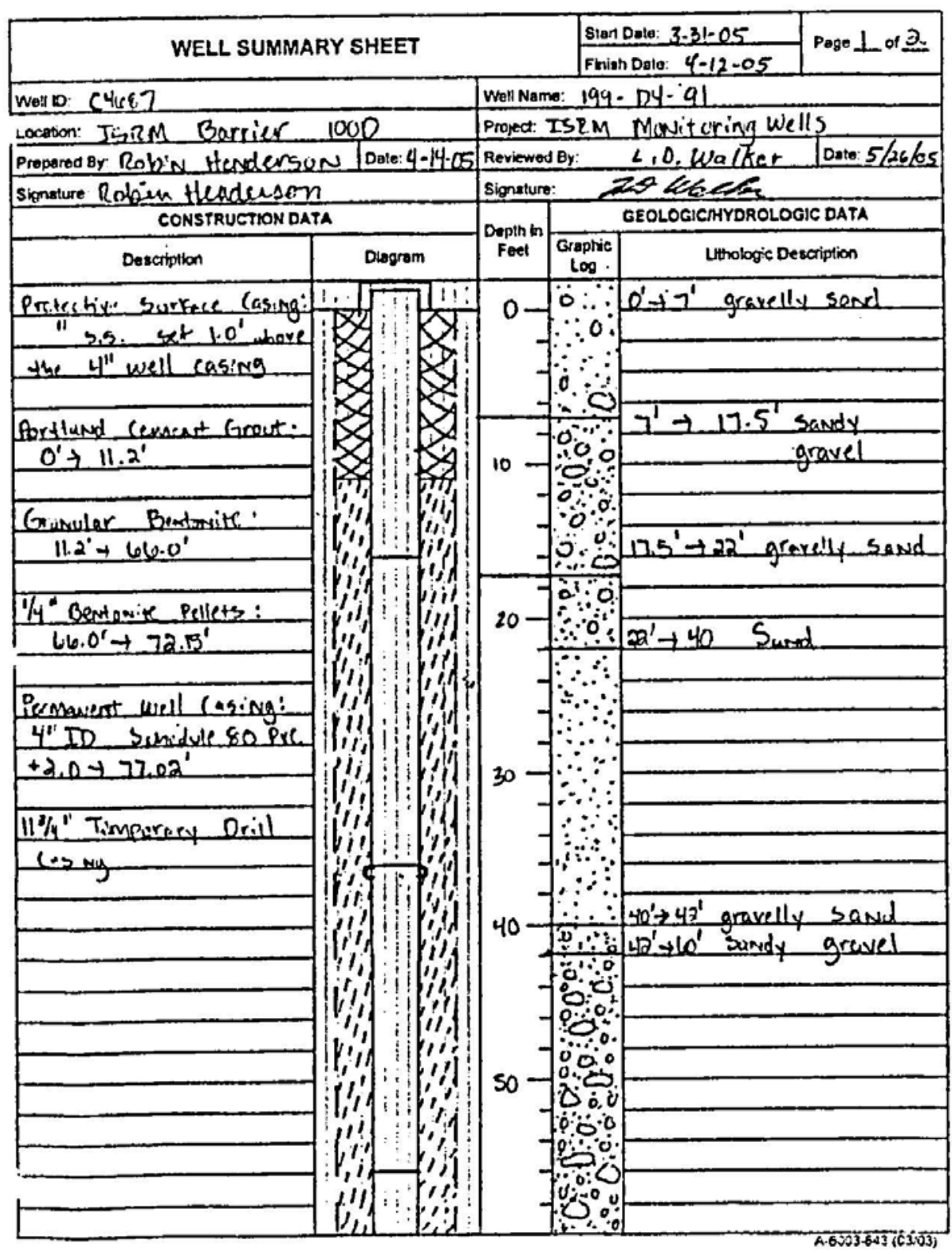

Figure A.8. Well 199-D4-91 
WMP-26460, REV. 0

\begin{tabular}{|c|c|c|c|c|c|}
\hline \multirow{2}{*}{\multicolumn{2}{|c|}{ WELL SUMMARY SHEET }} & & \multicolumn{2}{|c|}{ Stant Dale: $3.31-05$} & \multirow{2}{*}{ Page $\underline{2}$ of $\underline{2}$} \\
\hline & & & & $n$ Date: 4.12 .05 & \\
\hline$(468)$ & & \multicolumn{4}{|c|}{ Wel Name: $199-04-91$} \\
\hline Locaton: ISRM Barrier & 1000 & \multirow{2}{*}{\multicolumn{4}{|c|}{$\begin{array}{l}\text { Projoct ISRM Mavitaring Wells } \\
\text { Reviewed By: L,D.Walker Date: } 5 / 26 / 65\end{array}$}} \\
\hline \multirow{2}{*}{\multicolumn{2}{|c|}{ Prepared By: Rolvin Henderson Date: $4-1405$}} & & & & \\
\hline & & \multicolumn{4}{|c|}{ Signaturo: Lo Lece } \\
\hline \multicolumn{2}{|l|}{ CONSTRUCTION DATA } & \multirow{2}{*}{$\begin{array}{ll}\text { Depten } \\
\text { foet }\end{array}$} & \multicolumn{3}{|c|}{ GEOLOGICHYDROLOGIC DATA } \\
\hline Descriptian & Diagram & & $\begin{array}{c}\text { Graphic } \\
\text { Lo }\end{array}$ & Lithologic De & setpotion \\
\hline If" Bentroule Pellets: & & & & $6 x_{1}^{\prime}-75^{\prime}=112$ & Surdedy \\
\hline $66.0^{\prime}+72.15^{1}$ & Pin & & & giv & 1 \\
\hline Lolorado Silica Sand & $\forall=1,1,1,1$ & & & & \\
\hline $10-20$ mesh & xx & & & & \\
\hline $72.15^{\prime} \rightarrow 99.69^{\prime}$ & & & & & \\
\hline 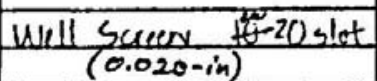 & $\because$ & & & $75^{\prime}+76.5^{\prime}$ & and \\
\hline $97.0^{\prime} \rightarrow 72.62^{\prime}$ & & & & & \\
\hline & $\because$ & 80 & & & \\
\hline Sump & & & & & \\
\hline $97.1^{1}+99.3^{\top}$ & 政: & & & $65^{\circ}+87^{\prime}$ slight & 7 silty soudy \\
\hline & $n=0$ & & & grave & \\
\hline Thtol lewenth of DYC & 1 & 90 & & $\frac{87^{\prime}+91^{\prime} \text { gravell }}{91^{\prime}+95^{\prime}}$ & Silty sund \\
\hline casing is 101.331 & $\because=$ & & $\therefore 0$ & & \\
\hline & 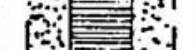 & & 0.0 & $45 \div 97.25^{\prime}-2$ & ightly_silt-1 \\
\hline & 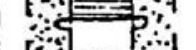 & & & & süvelly scand \\
\hline & {$\left[\begin{array}{ll}{[1} \\
{[}\end{array}\right]$} & $100-$ & & $97.25^{\circ}+99.69^{\prime}$ & silt \\
\hline & & & & $W . L .=83.0^{\prime}$ & \\
\hline All deoths are in feet & & & & $(4-5$ & $.05)$ \\
\hline belawe arand siry-ace. & & & & & \\
\hline & & & & & \\
\hline All tempreary cosing & & & & & \\
\hline was serioved from & & & & & \\
\hline yraxid & & & & & \\
\hline
\end{tabular}

Figure A.8 (contd) 
WMP-26460, REV. 0

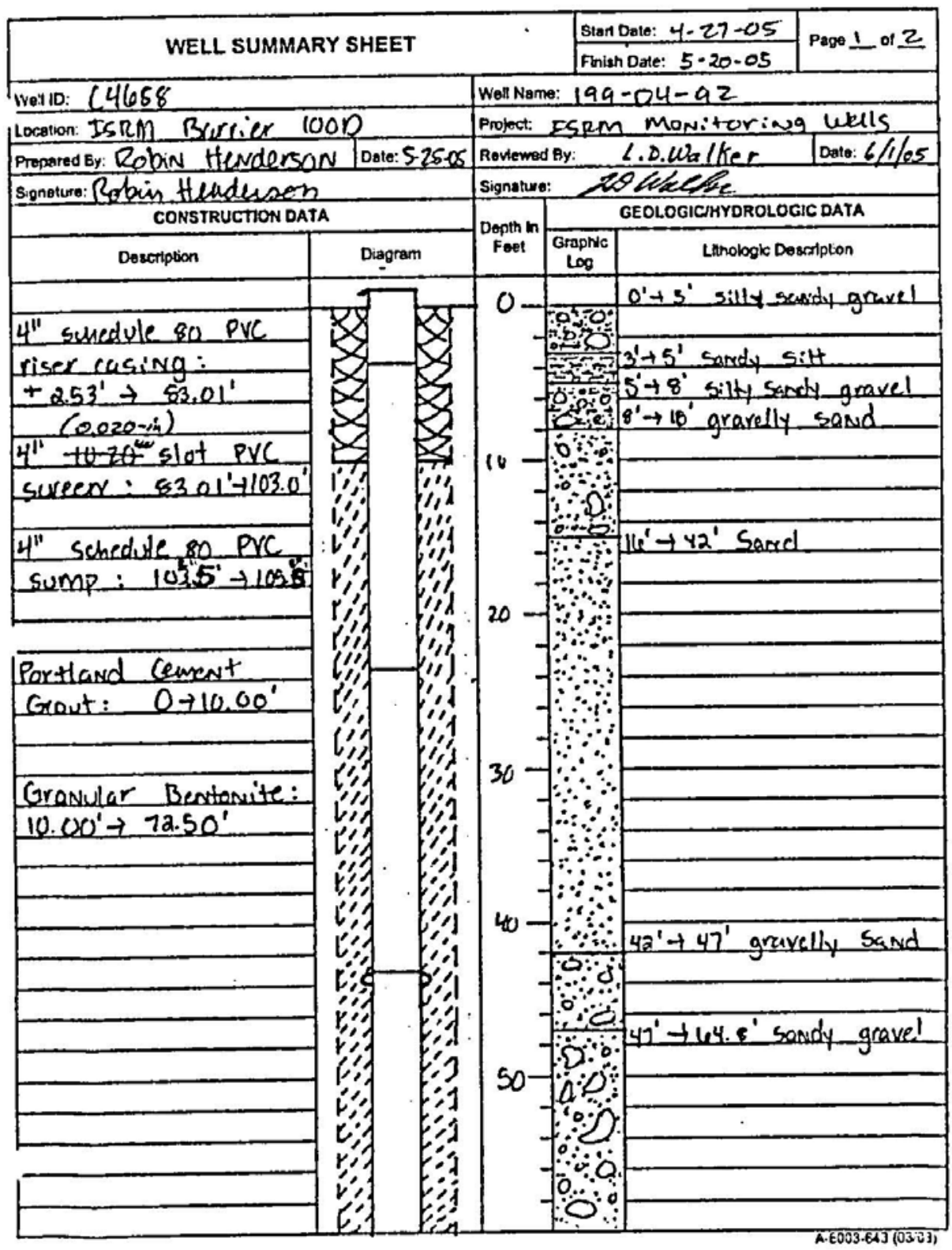

Figure A.9. Well 199-D4-92 
WMP-26460, REV. 0

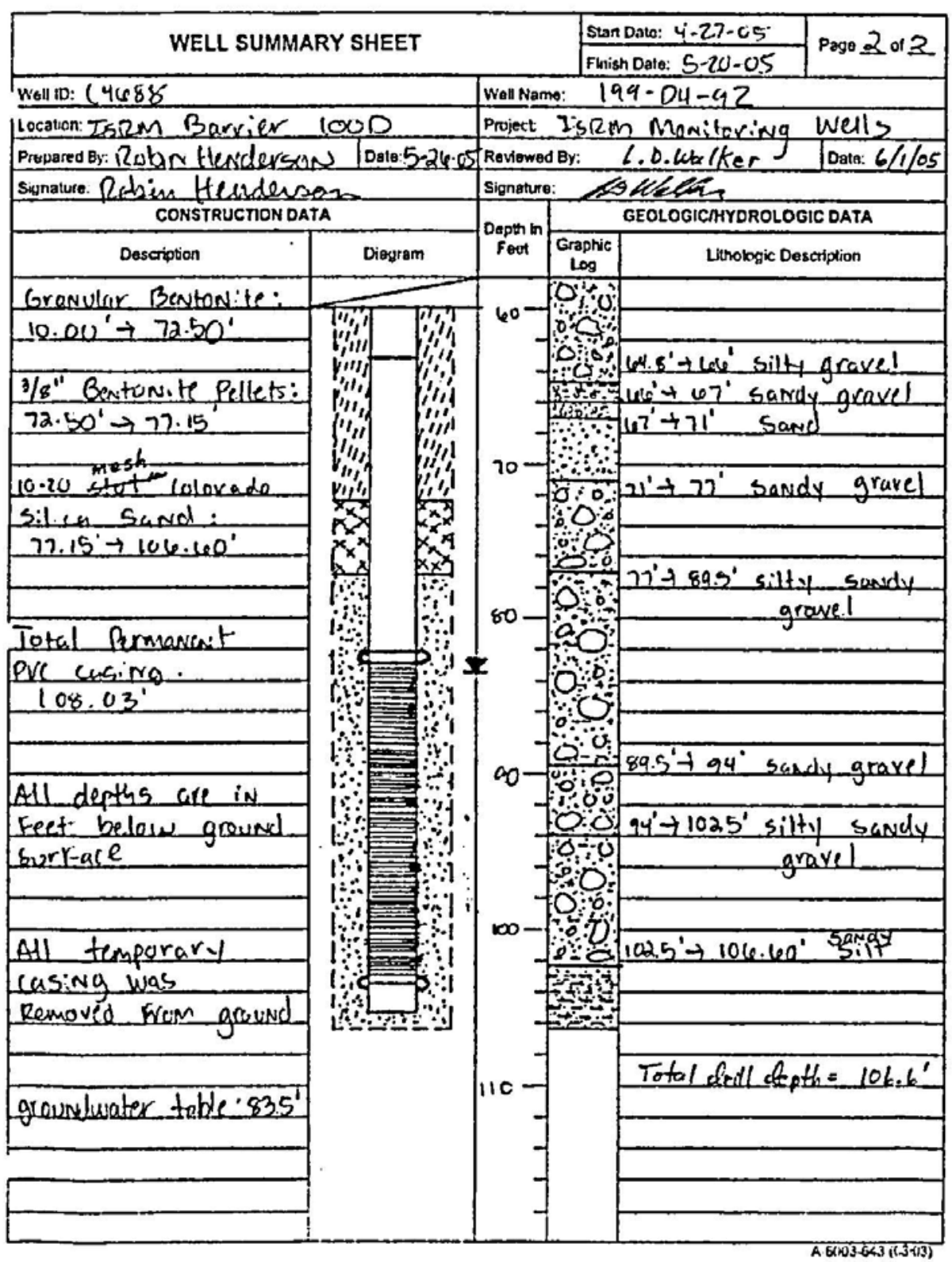

Figure A.9 (contd) 
WMP-26460, REV. 0

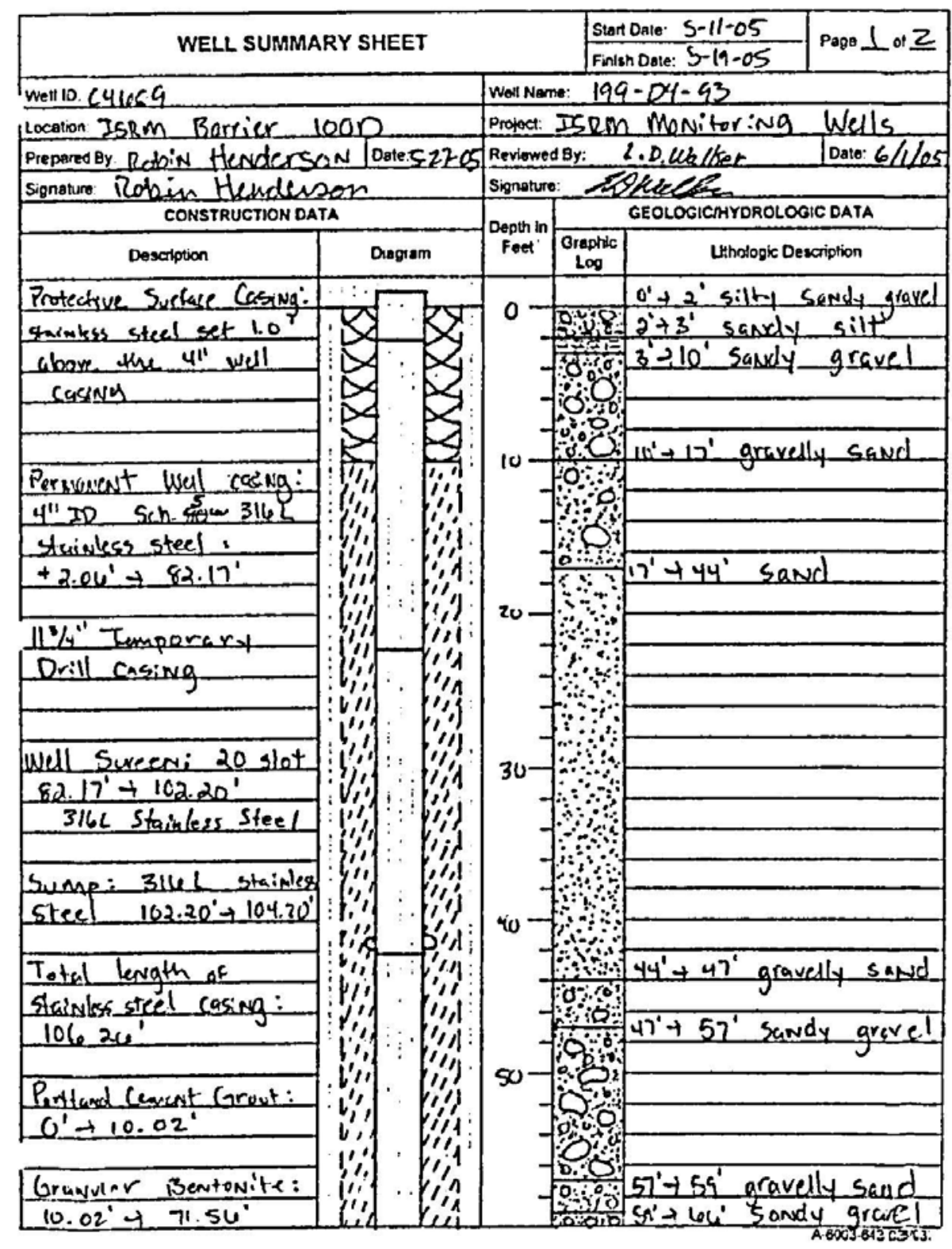

Figure A.10. Well 199-D4-93 
WMP-26460, REV. 0

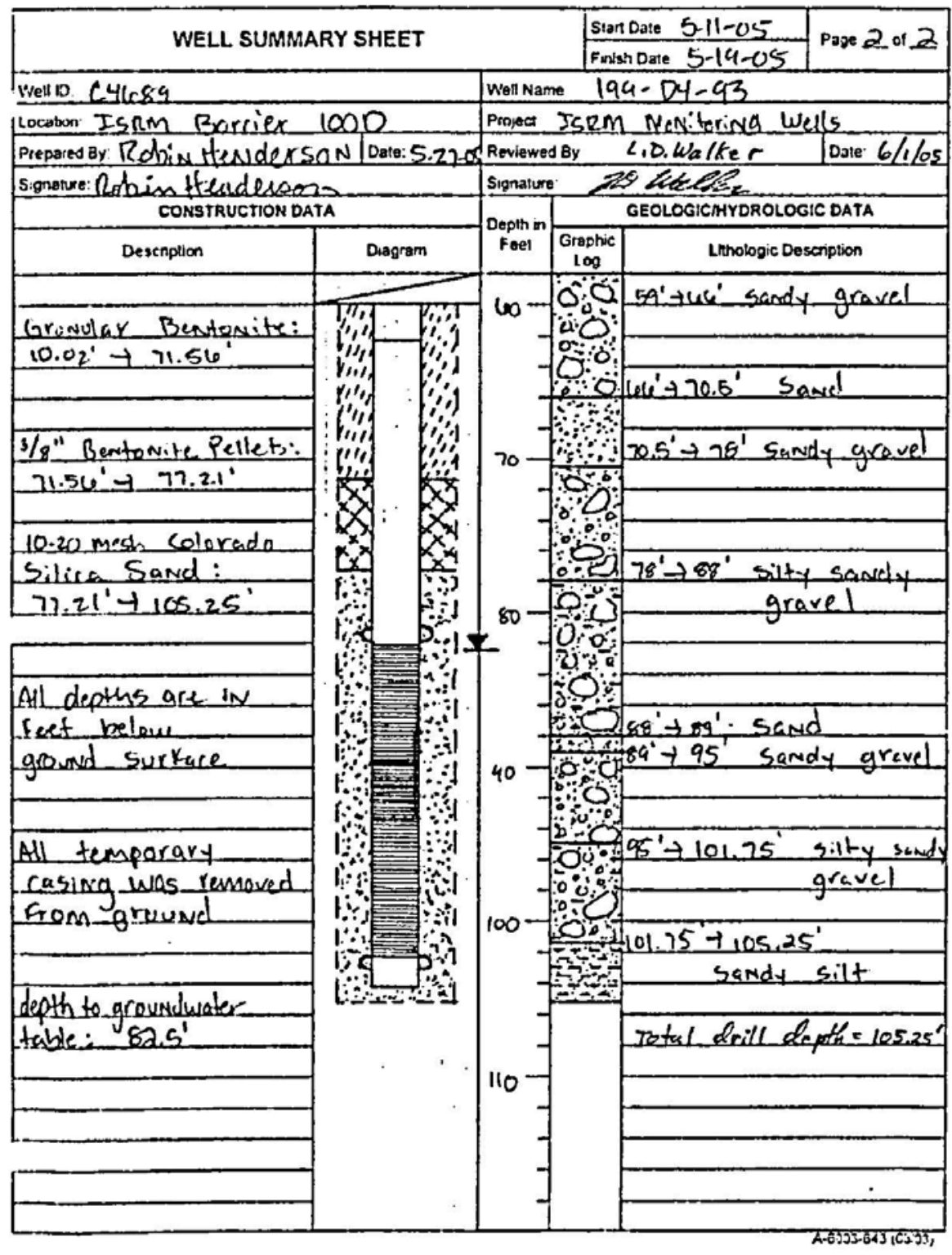

Figure A.10 (contd) 
Appendix B

\section{Summary of Electromagnetic Borehole} Flowmeter Analysis Results 


\section{Appendix B}

\section{Summary of Electromagnetic Borehole Flowmeter Analysis Results}

Table B.1. Well 199-D4-25

\begin{tabular}{|c|c|c|c|c|c|c|c|}
\hline $\begin{array}{c}\text { Ambient } \\
\text { Depth (ft bgs) }\end{array}$ & $\begin{array}{l}\text { Ambient } \\
\text { Flow (gpm) }\end{array}$ & $\begin{array}{l}\text { Ambient Standard } \\
\text { Deviation (gpm) }\end{array}$ & $\begin{array}{l}\text { Dynamic } \\
\text { Depth } \\
\text { (ft bgs) }\end{array}$ & $\begin{array}{l}\text { Dynamic } \\
\text { Flow (gpm) }\end{array}$ & $\begin{array}{c}\text { Dynamic } \\
\text { Standard } \\
\text { Deviation }(\mathrm{gpm})\end{array}$ & $\begin{array}{l}\text { Bypass Corrected } \\
\text { Net Flow (gpm) }\end{array}$ & $\begin{array}{c}\text { Relative } \\
\text { Hydraulic } \\
\text { Conductivity }\end{array}$ \\
\hline 99.0 & 0.000 & 0.015 & 99.0 & 0.000 & 0.013 & 0.000 & \\
\hline 98.2 & 0.019 & 0.011 & 98.2 & 0.053 & 0.014 & 0.063 & 0.051 \\
\hline 97.2 & 0.009 & 0.028 & 97.2 & 0.099 & 0.023 & 0.166 & 0.070 \\
\hline 96.2 & 0.017 & 0.017 & 96.2 & 0.153 & 0.028 & 0.249 & 0.057 \\
\hline 95.2 & 0.013 & 0.013 & 95.2 & 0.238 & 0.014 & 0.414 & 0.112 \\
\hline 94.2 & 0.017 & 0.020 & 94.2 & 0.247 & 0.022 & 0.423 & 0.006 \\
\hline 93.2 & 0.021 & 0.018 & 93.2 & 0.236 & 0.033 & 0.395 & -0.019 \\
\hline 92.2 & 0.024 & 0.015 & 92.2 & 0.366 & 0.036 & 0.630 & 0.159 \\
\hline 91.2 & 0.023 & 0.015 & 91.2 & 0.394 & 0.030 & 0.684 & 0.037 \\
\hline 90.2 & 0.017 & 0.016 & 90.2 & 0.434 & 0.036 & 0.767 & 0.057 \\
\hline 89.2 & 0.016 & 0.016 & 89.2 & 0.529 & 0.034 & 0.770 & 0.002 \\
\hline 88.2 & 0.012 & 0.016 & 88.2 & 0.458 & 0.051 & 0.820 & 0.034 \\
\hline 87.2 & 0.008 & 0.013 & 87.2 & 0.531 & 0.028 & 0.962 & 0.096 \\
\hline 86.2 & 0.004 & 0.014 & 86.2 & 0.617 & 0.033 & 1.127 & 0.113 \\
\hline 85.2 & 0.002 & 0.014 & 85.2 & 1.498 & 0.014 & 1.293 & 0.113 \\
\hline 84.0 & 0.000 & 0.010 & 84.0 & 1.488 & 0.049 & 1.488 & 0.113 \\
\hline
\end{tabular}


Table B.2. Well 199-D4-26

\begin{tabular}{|c|c|c|c|c|c|c|c|}
\hline $\begin{array}{c}\text { Ambient } \\
\text { Depth (ft bgs) }\end{array}$ & $\begin{array}{l}\text { Ambient } \\
\text { Flow (gpm) }\end{array}$ & $\begin{array}{l}\text { Ambient Standard } \\
\text { Deviation }(\mathrm{gpm})\end{array}$ & $\begin{array}{l}\text { Dynamic } \\
\text { Depth } \\
\text { (ft bgs) }\end{array}$ & $\begin{array}{l}\text { Dynamic } \\
\text { Flow (gpm) }\end{array}$ & $\begin{array}{c}\text { Dynamic } \\
\text { Standard } \\
\text { Deviation (gpm) }\end{array}$ & $\begin{array}{l}\text { Bypass Corrected } \\
\text { Net Flow (gpm) }\end{array}$ & $\begin{array}{c}\text { Relative } \\
\text { Hydraulic } \\
\text { Conductivity }\end{array}$ \\
\hline 100.0 & 0.000 & 0.004 & 100.0 & 0.000 & 0.025 & 0.000 & \\
\hline 99.6 & 0.009 & 0.005 & 99.6 & 0.129 & 0.027 & 0.269 & 0.363 \\
\hline 98.6 & 0.017 & 0.005 & 98.6 & 0.239 & 0.021 & 0.498 & 0.123 \\
\hline 97.6 & 0.027 & 0.006 & 97.6 & 0.343 & 0.024 & 0.709 & 0.114 \\
\hline 96.6 & 0.048 & 0.007 & 96.6 & 0.466 & 0.020 & 0.938 & 0.123 \\
\hline 95.6 & 0.080 & 0.005 & 95.6 & 0.569 & 0.020 & 1.097 & 0.086 \\
\hline 94.6 & 0.086 & 0.006 & 94.6 & 0.598 & 0.015 & 1.148 & 0.028 \\
\hline 93.6 & 0.085 & 0.005 & 93.6 & 0.626 & 0.017 & 1.213 & 0.035 \\
\hline 92.6 & 0.084 & 0.005 & 92.6 & 0.647 & 0.014 & 1.263 & 0.027 \\
\hline 91.6 & 0.094 & 0.005 & 91.6 & 1.012 & 0.012 & 1.259 & -0.002 \\
\hline 90.6 & 0.083 & 0.010 & 90.6 & 0.643 & 0.020 & 1.256 & -0.002 \\
\hline 89.6 & 0.081 & 0.007 & 89.6 & 0.689 & 0.022 & 1.364 & 0.058 \\
\hline 88.6 & 0.078 & 0.014 & 88.6 & 0.696 & 0.022 & 1.386 & 0.012 \\
\hline 87.6 & 0.076 & 0.015 & 87.6 & 0.708 & 0.025 & 1.418 & 0.017 \\
\hline 86.6 & 0.007 & 0.010 & 86.6 & 1.456 & 0.024 & 1.449 & 0.017 \\
\hline 85.6 & -0.001 & 0.018 & 85.6 & 1.448 & 0.021 & 1.480 & \\
\hline 85.0 & 0.000 & 0.014 & 85.0 & 1.459 & 0.012 & 1.499 & \\
\hline
\end{tabular}


Table B.3. Well 199-D4-27

\begin{tabular}{|c|c|c|c|c|c|c|c|}
\hline $\begin{array}{c}\text { Ambient } \\
\text { Depth (ft bgs) }\end{array}$ & $\begin{array}{c}\text { Ambient } \\
\text { Flow (gpm) }\end{array}$ & $\begin{array}{c}\text { Ambient Standard } \\
\text { Deviation (gpm) }\end{array}$ & $\begin{array}{l}\text { Dynamic } \\
\text { Depth } \\
\text { (ft bgs) }\end{array}$ & $\begin{array}{c}\text { Dynamic } \\
\text { Flow (gpm) }\end{array}$ & $\begin{array}{c}\text { Dynamic } \\
\text { Standard } \\
\text { Deviation }(\mathrm{gpm})\end{array}$ & $\begin{array}{l}\text { Bypass Corrected } \\
\text { Net Flow (gpm) }\end{array}$ & $\begin{array}{c}\text { Relative } \\
\text { Hydraulic } \\
\text { Conductivity }\end{array}$ \\
\hline 100.0 & 0.000 & 0.029 & 100.0 & 0.000 & 0.018 & 0.000 & \\
\hline 99.6 & 0.003 & 0.005 & 99.6 & 0.065 & 0.023 & 0.110 & 0.162 \\
\hline 98.6 & 0.023 & 0.005 & 98.6 & 0.165 & 0.026 & 0.252 & 0.084 \\
\hline 97.6 & 0.057 & 0.005 & 97.6 & 0.388 & 0.044 & 0.588 & 0.198 \\
\hline 96.6 & 0.093 & 0.004 & 96.6 & 0.442 & 0.049 & 0.620 & 0.019 \\
\hline 95.6 & 0.135 & 0.005 & 95.6 & 0.784 & 0.020 & 0.649 & 0.017 \\
\hline 94.6 & 0.113 & 0.005 & 94.6 & 0.495 & 0.018 & 0.678 & 0.017 \\
\hline 93.6 & 0.107 & 0.005 & 93.6 & 0.545 & 0.017 & 0.778 & 0.059 \\
\hline 92.6 & 0.086 & 0.005 & 92.6 & 0.599 & 0.039 & 0.911 & 0.078 \\
\hline 91.6 & 0.073 & 0.005 & 91.6 & 0.631 & 0.021 & 0.991 & 0.047 \\
\hline 90.6 & 0.061 & 0.005 & 90.6 & 0.613 & 0.065 & 0.980 & -0.006 \\
\hline 89.6 & 0.056 & 0.005 & 89.6 & 0.762 & 0.052 & 1.254 & 0.161 \\
\hline 88.6 & 0.043 & 0.005 & 88.6 & 0.695 & 0.044 & 1.158 & -0.056 \\
\hline 87.6 & 0.042 & 0.006 & 87.6 & 0.742 & 0.078 & 1.243 & 0.050 \\
\hline 86.6 & 0.033 & 0.006 & 86.6 & 0.788 & 0.042 & 1.341 & 0.058 \\
\hline 85.6 & -0.015 & 0.009 & 85.6 & 1.476 & 0.022 & 1.438 & 0.058 \\
\hline 85.0 & -0.003 & 0.008 & 85.0 & 1.492 & 0.026 & 1.495 & 0.056 \\
\hline
\end{tabular}


Table B.4. Well 199-D4-36

\begin{tabular}{|c|c|c|c|c|c|c|c|}
\hline $\begin{array}{c}\text { Ambient } \\
\text { Depth (ft bgs) }\end{array}$ & $\begin{array}{l}\text { Ambient } \\
\text { Flow (gpm) }\end{array}$ & $\begin{array}{l}\text { Ambient Standard } \\
\text { Deviation (gpm) }\end{array}$ & $\begin{array}{l}\text { Dynamic } \\
\text { Depth } \\
\text { (ft bgs) }\end{array}$ & $\begin{array}{c}\text { Dynamic } \\
\text { Flow (gpm) }\end{array}$ & $\begin{array}{c}\text { Dynamic } \\
\text { Standard } \\
\text { Deviation (gpm) }\end{array}$ & $\begin{array}{l}\text { Bypass Corrected } \\
\text { Net Flow (gpm) }\end{array}$ & $\begin{array}{c}\text { Relative } \\
\text { Hydraulic } \\
\text { Conductivity }\end{array}$ \\
\hline 96.3 & 0.000 & 0.006 & 96.3 & 0.000 & 0.023 & 0.000 & \\
\hline 95.6 & 0.001 & 0.006 & 95.6 & 0.065 & 0.055 & 0.122 & 0.103 \\
\hline 94.6 & 0.013 & 0.006 & 94.6 & 0.106 & 0.019 & 0.178 & 0.037 \\
\hline 93.6 & 0.027 & 0.005 & 93.6 & 0.140 & 0.021 & 0.216 & 0.026 \\
\hline 92.6 & 0.031 & 0.006 & 92.6 & 0.154 & 0.018 & 0.235 & 0.013 \\
\hline 91.6 & 0.032 & 0.005 & 91.6 & 0.142 & 0.015 & 0.210 & -0.017 \\
\hline 90.6 & 0.049 & 0.006 & 90.6 & 0.217 & 0.012 & 0.321 & 0.075 \\
\hline 89.6 & 0.057 & 0.005 & 89.6 & 0.346 & 0.019 & 0.553 & 0.156 \\
\hline 88.6 & 0.064 & 0.005 & 88.6 & 0.458 & 0.031 & 0.754 & 0.135 \\
\hline 87.6 & 0.072 & 0.005 & 87.6 & 0.563 & 0.018 & 0.940 & 0.125 \\
\hline 86.6 & 0.086 & 0.006 & 86.6 & 0.692 & 0.020 & 1.160 & 0.148 \\
\hline 85.6 & 0.100 & 0.014 & 85.6 & 0.788 & 0.013 & 1.317 & 0.105 \\
\hline 84.6 & 0.102 & 0.009 & 84.6 & 0.847 & 0.020 & 1.425 & 0.073 \\
\hline 83.6 & 0.097 & 0.011 & 83.6 & 0.859 & 0.022 & 1.458 & 0.022 \\
\hline
\end{tabular}


Table B.5. Well 199-D4-37

\begin{tabular}{cccccc}
\hline $\begin{array}{c}\text { Ambient } \\
\text { Depth (ft bgs) }\end{array}$ & $\begin{array}{c}\text { Ambient } \\
\text { Flow }(\mathrm{gpm})\end{array}$ & $\begin{array}{c}\text { Ambient Standard } \\
\text { Deviation }(\mathrm{gpm})\end{array}$ & $\begin{array}{c}\text { Dynamic } \\
\text { Depth }(\mathrm{ft} \text { bgs })\end{array}$ & $\begin{array}{c}\text { Dynamic } \\
\text { Flow (gpm) }\end{array}$ & $\begin{array}{c}\text { Dynamic Standard } \\
\text { Deviation }(\mathrm{gpm})\end{array}$ \\
\hline 97.6 & 0.000 & 0.013 & 97.6 & 0.000 & 0.021 \\
96.7 & 0.020 & 0.013 & 96.7 & 0.136 & 0.014 \\
95.7 & 0.020 & 0.014 & 95.7 & 0.110 & 0.011 \\
94.7 & 0.036 & 0.010 & 94.7 & 0.170 & 0.015 \\
93.7 & 0.032 & 0.013 & 93.7 & 0.189 & 0.018 \\
92.7 & 0.024 & 0.010 & 92.7 & 0.235 & 0.018 \\
91.7 & 0.046 & 0.010 & 91.7 & 0.280 & 0.015 \\
90.7 & 0.058 & 0.013 & 90.7 & 0.329 & 0.022 \\
89.7 & 0.068 & 0.005 & 89.7 & 0.447 & 0.024 \\
88.7 & 0.075 & 0.005 & 88.7 & 0.564 & 0.018 \\
87.7 & 0.065 & 0.005 & 87.7 & 0.560 & 0.020 \\
86.7 & 0.066 & 0.004 & 86.7 & 0.488 & 0.016 \\
85.7 & 0.063 & 0.004 & 85.7 & 0.916 & 0.019 \\
84.7 & 0.059 & 0.005 & 84.7 & 1.991 & 0.032 \\
\hline
\end{tabular}


Table B.6. Well 199-D4-40

\begin{tabular}{cccccc}
\hline $\begin{array}{c}\text { Ambient } \\
\text { Depth (ft bgs) }\end{array}$ & $\begin{array}{c}\text { Ambient } \\
\text { Flow (gpm) }\end{array}$ & $\begin{array}{c}\text { Ambient Standard } \\
\text { Deviation (gpm) }\end{array}$ & $\begin{array}{c}\text { Dynamic } \\
\text { Depth (ft bgs) }\end{array}$ & $\begin{array}{c}\text { Dynamic } \\
\text { Flow (gpm) }\end{array}$ & $\begin{array}{c}\text { Dynamic Standard } \\
\text { Deviation (gpm) }\end{array}$ \\
\hline 97.0 & 0.000 & 0.006 & 97.0 & 0.000 & 0.020 \\
96.5 & 0.007 & 0.005 & 96.5 & -0.020 & 0.015 \\
95.5 & 0.016 & 0.005 & 95.5 & -0.029 & 0.016 \\
94.5 & 0.015 & 0.005 & 94.5 & 0.008 & 0.011 \\
93.5 & 0.020 & 0.006 & 93.5 & 0.002 & 0.018 \\
92.5 & 0.016 & 0.006 & 92.5 & 0.030 & 0.018 \\
91.5 & 0.014 & 0.008 & 91.5 & 0.049 & 0.022 \\
90.5 & 0.017 & 0.008 & 90.5 & 0.091 & 0.024 \\
89.5 & 0.013 & 0.008 & 89.5 & 0.110 & 0.021 \\
88.5 & 0.009 & 0.010 & 88.5 & 0.101 & 0.020 \\
87.5 & 0.012 & 0.015 & 87.5 & 0.160 & 0.015 \\
86.5 & 0.018 & 0.013 & 86.5 & 0.164 & 0.021 \\
85.5 & 0.018 & 0.011 & 85.5 & 0.174 & 0.012 \\
84.5 & 0.012 & 0.014 & 84.5 & 0.179 & 0.023 \\
84.0 & 0.018 & 0.013 & 84.0 & 0.373 & 0.052 \\
\hline
\end{tabular}


Table B.7. Well 199-D4-90

\begin{tabular}{|c|c|c|c|c|c|c|c|}
\hline $\begin{array}{c}\text { Ambient } \\
\text { Depth (ft bgs) }\end{array}$ & $\begin{array}{l}\text { Ambient } \\
\text { Flow (gpm) }\end{array}$ & $\begin{array}{l}\text { Ambient Standard } \\
\text { Deviation (gpm) }\end{array}$ & $\begin{array}{l}\text { Dynamic } \\
\text { Depth } \\
\text { (ft bgs) }\end{array}$ & $\begin{array}{l}\text { Dynamic } \\
\text { Flow (gpm) }\end{array}$ & $\begin{array}{c}\text { Dynamic } \\
\text { Standard } \\
\text { Deviation (gpm) }\end{array}$ & Net Flow (gpm) & $\begin{array}{c}\text { Relative } \\
\text { Hydraulic } \\
\text { Conductivity }\end{array}$ \\
\hline 97.8 & 0.000 & 0.005 & 97.8 & 0 & 0.039 & 0.000 & \\
\hline 96.5 & 0.020 & 0.006 & 96.5 & 0.019 & 0.038 & -0.001 & -0.001 \\
\hline 95.5 & 0.028 & 0.007 & 95.5 & 0.081 & 0.035 & 0.053 & 0.080 \\
\hline 94.5 & 0.027 & 0.006 & 94.5 & 0.067 & 0.041 & 0.040 & -0.018 \\
\hline 93.5 & 0.024 & 0.005 & 93.5 & 0.143 & 0.026 & 0.119 & 0.116 \\
\hline 92.5 & 0.023 & 0.006 & 92.5 & 0.194 & 0.041 & 0.171 & 0.076 \\
\hline 91.5 & 0.022 & 0.006 & 91.5 & 0.172 & 0.035 & 0.150 & -0.031 \\
\hline 90.5 & 0.032 & 0.008 & 90.5 & 0.378 & 0.061 & 0.346 & 0.288 \\
\hline 89.5 & 0.002 & 0.013 & 89.5 & 0.417 & 0.043 & 0.415 & 0.101 \\
\hline 88.5 & -0.001 & 0.009 & 88.5 & 0.449 & 0.034 & 0.450 & 0.052 \\
\hline 87.5 & -0.004 & 0.015 & 87.5 & 0.463 & 0.021 & 0.467 & 0.024 \\
\hline 86.5 & -0.001 & 0.016 & 86.5 & 0.536 & 0.046 & 0.537 & 0.103 \\
\hline 85.5 & -0.001 & 0.016 & 85.5 & 0.546 & 0.021 & 0.547 & 0.015 \\
\hline 84.5 & -0.004 & 0.022 & 84.5 & 0.609 & 0.025 & 0.613 & 0.098 \\
\hline 82.8 & 0.000 & 0.011 & 82.8 & & & & 0.098 \\
\hline
\end{tabular}


Table B.8. Well 199-D4-91

\begin{tabular}{|c|c|c|c|c|c|c|c|}
\hline $\begin{array}{c}\text { Ambient } \\
\text { Depth (ft bgs) }\end{array}$ & $\begin{array}{c}\text { Ambient } \\
\text { Flow (gpm) }\end{array}$ & $\begin{array}{l}\text { Ambient Standard } \\
\text { Deviation (gpm) }\end{array}$ & $\begin{array}{l}\text { Dynamic } \\
\text { Depth } \\
\text { (ft bgs) }\end{array}$ & $\begin{array}{l}\text { Dynamic } \\
\text { Flow (gpm) }\end{array}$ & $\begin{array}{c}\text { Dynamic } \\
\text { Standard } \\
\text { Deviation (gpm) }\end{array}$ & $\begin{array}{l}\text { Bypass Corrected } \\
\text { Net Flow (gpm) }\end{array}$ & $\begin{array}{c}\text { Relative } \\
\text { Hydraulic } \\
\text { Conductivity }\end{array}$ \\
\hline 97.0 & 0.000 & 0.011 & 97.0 & 0.000 & 0.008 & 0.000 & \\
\hline 96.7 & 0.026 & 0.012 & 96.7 & 0.051 & 0.017 & 0.056 & 0.233 \\
\hline 95.7 & 0.039 & 0.013 & 95.7 & 0.054 & 0.007 & 0.033 & -0.033 \\
\hline 94.7 & 0.065 & 0.012 & 94.7 & 0.020 & 0.008 & 0.010 & -0.034 \\
\hline 93.7 & 0.042 & 0.012 & 93.7 & 0.073 & 0.007 & 0.069 & 0.086 \\
\hline 92.7 & -0.020 & 0.005 & 92.7 & 0.055 & 0.008 & 0.167 & 0.144 \\
\hline 91.7 & -0.018 & 0.006 & 91.7 & 0.040 & 0.006 & 0.129 & -0.055 \\
\hline 90.7 & -0.009 & 0.008 & 90.7 & 0.052 & 0.008 & 0.136 & 0.010 \\
\hline 89.7 & -0.028 & 0.008 & 89.7 & 0.097 & 0.007 & 0.279 & 0.209 \\
\hline 88.7 & -0.017 & 0.008 & 88.7 & 0.149 & 0.008 & 0.370 & 0.134 \\
\hline 87.7 & -0.044 & 0.006 & 87.7 & 0.179 & 0.010 & 0.497 & 0.186 \\
\hline 86.7 & -0.050 & 0.006 & 86.7 & 0.161 & 0.007 & 0.471 & -0.039 \\
\hline 85.7 & -0.087 & 0.007 & 85.7 & 0.152 & 0.012 & 0.533 & 0.091 \\
\hline 84.7 & -0.091 & 0.006 & 84.7 & 0.169 & 0.013 & 0.580 & 0.069 \\
\hline 83.7 & -0.096 & 0.005 & & & & & \\
\hline 82.7 & -0.114 & 0.005 & & & & & \\
\hline
\end{tabular}


Table B.9. Well 199-D4-92

\begin{tabular}{cccccc}
\hline $\begin{array}{c}\text { Ambient } \\
\text { Depth (ft bgs) }\end{array}$ & $\begin{array}{c}\text { Ambient } \\
\text { Flow }(\mathrm{gpm})\end{array}$ & $\begin{array}{c}\text { Ambient Standard } \\
\text { Deviation (gpm) }\end{array}$ & $\begin{array}{c}\text { Dynamic } \\
\text { Depth (ft bgs })\end{array}$ & $\begin{array}{c}\text { Dynamic } \\
\text { Flow (gpm) }\end{array}$ & $\begin{array}{c}\text { Dynamic Standard } \\
\text { Deviation (gpm) }\end{array}$ \\
\hline 101.4 & 0.000 & 0.004 & 101.4 & 0.000 & 0.007 \\
100.4 & 0.079 & 0.006 & 100.4 & 0.008 & 0.006 \\
99.4 & 0.079 & 0.006 & 99.4 & 0.042 & 0.008 \\
98.4 & 0.084 & 0.005 & 98.4 & 0.025 & 0.009 \\
97.4 & 0.048 & 0.005 & 97.4 & 0.045 & 0.009 \\
96.4 & 0.069 & 0.006 & 96.4 & 0.021 & 0.007 \\
95.4 & 0.063 & 0.006 & 95.4 & 0.028 & 0.005 \\
94.4 & 0.054 & 0.007 & 94.4 & 0.056 & 0.007 \\
93.4 & 0.012 & 0.009 & 93.4 & 0.088 & 0.007 \\
92.4 & 0.019 & 0.008 & 92.4 & 0.088 & 0.009 \\
91.4 & -0.001 & 0.010 & 91.4 & 0.079 & 0.009 \\
90.4 & -0.010 & 0.011 & 90.4 & 0.085 & 0.006 \\
89.4 & -0.005 & 0.009 & 89.4 & 0.081 & 0.009 \\
88.4 & -0.035 & 0.009 & 88.4 & 0.087 & 0.005 \\
87.4 & -0.047 & 0.015 & 87.4 & 0.122 & 0.009 \\
86.4 & -0.038 & 0.009 & 86.4 & 0.115 & 0.005 \\
85.4 & -0.048 & 0.011 & 85.4 & 0.160 & 0.008 \\
84.4 & -0.059 & 0.011 & 84.4 & 0.288 & 0.029 \\
83.4 & -0.076 & 0.010 & & & \\
\hline
\end{tabular}


Table B.10. Well 199-D4-93

\begin{tabular}{|c|c|c|c|c|c|c|c|}
\hline $\begin{array}{l}\text { Ambient } \\
\text { Depth } \\
\text { (ft bgs) }\end{array}$ & $\begin{array}{c}\text { Ambient } \\
\text { Flow (gpm) }\end{array}$ & $\begin{array}{l}\text { Ambient Standard } \\
\text { Deviation (gpm) }\end{array}$ & $\begin{array}{c}\text { Dynamic } \\
\text { Depth (ft bgs) }\end{array}$ & $\begin{array}{c}\text { Dynamic } \\
\text { Flow (gpm) }\end{array}$ & $\begin{array}{c}\text { Dynamic Standard } \\
\text { Deviation (gpm) }\end{array}$ & $\begin{array}{l}\text { Bypass Corrected } \\
\text { Net Flow (gpm) }\end{array}$ & $\begin{array}{c}\text { Relative Hydraulic } \\
\text { Conductivity }\end{array}$ \\
\hline 101.5 & 0.000 & 0.011 & 101.5 & 0.000 & 0.044 & 0.000 & \\
\hline 100.5 & 0.061 & 0.014 & 100.5 & 0.042 & 0.071 & -0.042 & -0.031 \\
\hline 99.5 & 0.057 & 0.006 & 99.5 & 0.092 & 0.047 & 0.077 & 0.089 \\
\hline 98.5 & 0.096 & 0.011 & 98.5 & 0.115 & 0.030 & 0.042 & -0.026 \\
\hline 97.5 & 0.080 & 0.011 & 97.5 & 0.262 & 0.020 & 0.403 & 0.269 \\
\hline 96.5 & 0.074 & 0.011 & 96.5 & 0.232 & 0.018 & 0.350 & -0.040 \\
\hline 95.5 & 0.076 & 0.012 & 95.5 & 0.279 & 0.013 & 0.449 & 0.074 \\
\hline 94.5 & 0.085 & 0.013 & 94.5 & 0.304 & 0.039 & 0.484 & 0.026 \\
\hline 93.5 & 0.090 & 0.010 & 93.5 & 0.359 & 0.028 & 0.595 & 0.083 \\
\hline 92.5 & 0.066 & 0.008 & 92.5 & 0.373 & 0.020 & 0.679 & 0.063 \\
\hline 91.5 & 0.046 & 0.006 & 91.5 & 0.411 & 0.021 & 0.807 & 0.096 \\
\hline 90.5 & 0.014 & 0.007 & 90.5 & 0.409 & 0.028 & 0.874 & 0.050 \\
\hline 89.5 & 0.008 & 0.005 & 89.5 & 0.473 & 0.019 & 1.029 & 0.116 \\
\hline 88.5 & 0.000 & 0.004 & 88.5 & 0.476 & 0.020 & 1.053 & 0.018 \\
\hline 87.5 & -0.007 & 0.004 & 87.5 & 0.447 & 0.029 & 1.004 & -0.036 \\
\hline 86.5 & -0.010 & 0.004 & 86.5 & 0.528 & 0.052 & 1.190 & 0.139 \\
\hline 85.5 & -0.014 & 0.004 & 85.5 & 0.558 & 0.048 & 1.265 & 0.056 \\
\hline 84.5 & -0.036 & 0.005 & 84.5 & 0.569 & 0.025 & 1.338 & 0.055 \\
\hline 83.5 & -0.047 & 0.005 & & & & & \\
\hline 82.5 & -0.077 & 0.010 & & & & & \\
\hline
\end{tabular}


PNNL-18218

\section{Distribution}

No. of

Copies

OFFSITE

2 MSE Technology Applications, Inc.

PO Box 4078

Butte MT 59701-4078

Attn: Jason Modrell

email: Jason.modrell@mse-ta.com

Marek Zaluski

email: Marek.Zaluski@mse-ta.com
No. of

Copies

ONSITE

1 CH2M Hill Plateau Remediation Company (CHPRC)

S. W. Petersen E6-35

11 Pacific Northwest National Laboratory

J. S. Fruchter

K6-96

D. R. Newcomer (5)

K6-96

F. A. Spane

K6-96

V. R. Vermeul

K6-96

M. D. Williams

K6-96

Hanford Technical Library (2) 